UNIVERSIDADE DE SÃO PAULO
ESCOLA DE ARTES, CIÊNCIAS E HUMANIDADES
PROGRAMA DE PÓS-GRADUAÇÃO EM ESTUDOS CULTURAIS

EVANY BETTINE DE ALMEIDA

Tempos sociais nas instituições para idosos: os desafios temporais e os ritmos diários 
EVANY BETTINE DE ALMEIDA

\title{
Tempos sociais nas instituições para idosos: os desafios temporais e os ritmos diários
}

\author{
Versão Original
}

Dissertação apresentada à Escola de Artes, Ciências e Humanidades da Universidade de São Paulo para obtenção do título de Mestre em Filosofia pelo Programa de Pós-graduação em Estudos Culturais.

Área de concentração:

Cultura Saúde e Educação

Orientador:

Prof. Dr. Luiz Silveira Menna Barreto 
Autorizo a reprodução e divulgação total ou parcial deste trabalho, por qualquer meio convencional ou eletrônico, para fins de estudo e pesquisa, desde que citada a fonte.

Tempos sociais nas instituições para idosos : os desafios temporais e as rotinas diárias / Evany Bettine de Almeida ; orientador, Luiz Silveira Menna Barreto. - São Paulo, 2016 $138 \mathrm{f}$.

Dissertação (Mestrado em Filosofia) - Programa de PósGraduação em Estudos Culturais, Escola de Artes, Ciências e Humanidades, Universidade de São Paulo, São Paulo.

Versão original

1. Idosos - Aspectos sociais. 2. Cronobiologia. 3. Ritmos biológicos em humanos - Aspectos sociais. 4. Ritmos biológicos em humanos - Aspectos antropológicos. 5. Sincronização. I. Menna Barreto, Luiz Silveira, orient. II. Título 
Nome: ALMEIDA, Evany Bettine

Título: Tempos sociais nas instituições para idosos: os desafios temporais e os ritmos diários

Dissertação apresentada à Escola de Artes, Ciências e Humanidades da Universidade de São Paulo para obtenção do título de Mestre em Filosofia do Programa de Pós-Graduação em Estudos Culturais.

Área de Concentração:

Cultura Saúde e Educação

Aprovado em:

1

\section{Banca Examinadora}

Prof. Dr.

Instituição:

Julgamento:

Assinatura:

Prof. Dr.

Instituição:

Julgamento:

Assinatura:

Prof. Dr.

Instituição:

Julgamento:

Assinatura: 


\section{Agradecimentos}

Acredito que a nossa trajetória de vida seja traçada por nós mesmos. Acredito também que para dar sentido à nossa existência é primordial a busca pelo conhecimento e pelo aprimoramento intelectual.

Isto se aplica a todo o nosso curso de vida, não importa em que ponto da caminhada estejamos. Por isto sou grata pela escolha que fiz há cerca de uma década, dando outro rumo à minha trajetória, a qual talvez se encaminhasse para uma vida tranquila e sem obrigações. Certamente foi menos tranquila, no entanto, não seria tão rica e tão plural quanto tem sido o caminho que ora trilho, transitando pela gerontologia, pela cronobiologia, ambas, por fim amalgamadas nos Estudos Culturais.

Os amigos, os docentes que me ajudaram nesta caminhada, em especial o meu orientador, bem como a família, acabam todos por tecer uma nova rede de relacionamentos, indubitavelmente mais produtiva que reverbera para o coletivo. Produtiva no sentido mais filosófico da palavra, ou seja, produtividade não como rendimento, mas como fecundidade. 


\section{$\underline{\text { Retrato }}$}

Eu não tinha este rosto de hoje, assim calmo, assim triste, assim magro,

nem estes olhos tão vazios, nem o lábio amargo.

Eu não tinha estas mãos sem força, tão paradas e frias e mortas; eu não tinha este coração que nem se mostra.

Eu não dei por esta mudança, tão simples, tão certa, tão fácil:

- Em que espelho ficou perdida a minha face?

Cecília Meireles (Antologia Poética, 2001). 


\section{RESUMO}

ALMEIDA, Evany Bettine. Tempos sociais nas instituições para idosos - os desafios temporais e os ritmos diários. 2016. 138 pg. Dissertação (Mestrado em Estudos Culturais) - Escola de Artes, Ciências e Humanidades, Universidade de São Paulo, São Paulo, 2016. Versão original.

Este é um estudo sobre regras temporais às quais residentes em instituições asilares são submetidos e os possíveis impactos que a homogeneização de horários e duração das atividades podem exercer sobre seus ritmos biológicos. A homogeneização dos tempos sociais pode causar dessincronização temporal interna, o que interfere nos processos corporais causando dessincronização temporal externa, isto é: desajustes entre eventos ambientais e fisiológicos, criando problemas nos ciclos de vigília/sono e humor, entre outros colaborando para o declínio do desempenho cognitivo. Em um ambiente asilar, preferências pessoais relacionadas à fixação de horários e duração das atividades em geral, não são consideradas. Entendo que pelo exercício do poder e pelo disciplinamento ao longo do curso de vida, os velhos que vivem em instituições tendem a naturalizar as normas estabelecidas; submissão essa que entendo ocorrer com as minorias em geral. Considero importante reconhecer as vontades dessas pessoas, atentando-se para suas identidades como pessoas e não apenas como corpos para serem cuidados, independentes dos sujeitos que os possuem. Localizo este trabalho no campo dos Estudos Culturais seguindo uma das suas tendências que é a do estudo etnográfico de populações envolvendo questões de gênero, raça e etnia, principalmente se tratando de uma minoria. Questões de corpo, solidão e indivíduo foram consideradas, juntamente com a cronobiologia, estudo dos ritmos biológicos, sendo o mais conhecido o ritmo circadiano. Participaram desta pesquisa 29 residentes, sendo 21 mulheres e 8 homens, com idades entre 75 e 99 anos de seis unidades de duas instituições para idosos, na zona leste e na zona sul do município de São Paulo-SP. A primeira técnica aplicada foi a observação selvagem, que consiste em observar situações, buscando ao máximo manter neutralidade em relação ao ambiente, o que já permitiu observar resistência aos horários de refeições, cochilos diurnos, mau humor, estado geral de apatia e tempo na cama superior a 13 horas. Instrumentos e técnicas: a) Questionário sociodemográfico (dados pessoais, satisfação geral com a vida e escala de depressão geriátrica); b) Diário de sono; c) Questionário de determinação de cronotipo - matutinidade/vespertinidade); d) Entrevista gravada; e) Técnica etnográfica da observação participante; f) Análises estatísticas; g) Análise do discurso para as entrevistas gravadas e dados de observação. Resultados e conclusões: os residentes não têm críticas sobre a rotina e horários e não proporiam mudanças; a maioria apresentou tendência à distimia e à depressão maior; mesmo os residentes que têm preferências vespertinas dormem cedo; a maioria relatou não ter apetite; apenas $10 \%$ residem por escolha própria; a desorganização temporal nos idosos foi parcialmente comprovada. Em função dos discursos analisados concluiu-se que as regras temporais são um dos desafios, dada a identificação de inúmeros fatores que influenciam negativamente a vida em uma instituição asilar.

Palavras-chave: Tempos sociais. Sincronização social. Conflito temporal. Atrito temporal. Instituição asilar. 


\begin{abstract}
ALMEIDA, Evany Bettine. Social times in institutions for the elderly - the temporal challenges and daily rhythms. 2016. 138p. Dissertation (Masters in Cultural Studies) School of Arts, Sciences and Humanities, University of São Paulo, São Paulo, 2016. Original version.

This is a study of temporal rules that residents in nursing homes are subjected and the potential impacts on their biological rhythms that the homogenization of time and duration of the activities may cause. The homogenization of social time can lead to internal temporal desynchronization, which interferes with bodily processes causing external temporal desynchronization, this means imbalances between environmental and physiological events which may produce problems in their sleep/wake cycles, mood, among others, contributing to the decline of cognitive performance. Personal preferences of timing and duration of activities in nursing homes are not considered, in general. I understand that old people living in institutions tend to naturalize the established norms because of the exercise of power and discipline throughout their course of life, submission to the rules usually found in minorities. I consider important to recognize the choices of these people, attending to their identities as individuals and not just as bodies to be maintained, independent of the individuals who own them. This work is in the field of Cultural Studies following one of its trends that is the ethnographic study of populations involving gender, race and ethnicity, especially when dealing with a minority. Body issues, loneliness and the individual will be considered in the field of chronobiology - the study of biological rhythms, as the circadian rhythm, present in almost all biological phenomena. Participated in this study 29 residents, 21 women and 8 men, aged between 75 and 99 years from six units of two nursing homes in the east and in the south of São Paulo-SP. The first technique applied was the Wild Observation, which consists in the observation trying to maintain neutrality towards the environment, which allowed us to witness conflicts with meal times; daytime naps; bad mood; general state of apathy; longer than 13 hours in bed. Instruments and techniques were applied: a) Sociodemographic; b) Sleep Diary; c) Chronotype; d) Recorded interview; e) Participant Observation; f) Statistics Analysis; g) Discourse Analysis for the recorded interviews and observation data. The main results and conclusions include the absence of criticisms concerning daily routines without proposition of changes; signs of depression and dystimia were observed in the majority of the population studied, evening type individuals going to bed early, generalized loss of appetite, and a minority of $10 \%$ chose to live in the institution; temporal disorganization in the elderly was partially confirmed. According to the speech analyses it was concluded that the temporal rules are a challenge and there are several factors that negatively influencing life in a nursing home.
\end{abstract}

Keywords: Social Time. Social Synchronization. Temporal Conflicts. Temporal Friction. Nursing Home. 


\section{Lista de Figuras}

Figura 1 - Satisfação geral com a vida......................................................... 48

Figura 2 - $\quad$ Resultados dos testes de Kolmogorov-Smirnov e Shapiro-Wilk......... $\quad 52$

Figura 3 - $\quad$ Idade entre os gêneros................................................................. 53

Figura 4 - $\quad$ Distribuição da pontuação (cronotipo) entre homens e mulheres....... 53

Figura 5 - Horários em que dormiram e acordaram os idosos entrevistados...... 54

Figura 6 - Idade entre os participantes de grupos diferentes (ter acordado e 55 dormido novamente).

Figura 7 - Pontuação entre os participantes de diferentes grupos no 55 questionário do cronotipo (matutinidade/vespertinidade).....

Figura 8 - $\quad$ Distribuição dos horários nos quais dormiram e acordaram.............. 56

Figura 9 - $\quad$ Idade entre os participantes de grupos diferentes (foram acordados 57 ou despertaram espontaneamente).....

Figura 10 - Pontuação entre os participantes de diferentes grupos (foram 57 acordados ou despertaram espontaneamente).

Figura 11 - Distribuição dos horários que dormiram e acordaram em grupos 58 diferentes (foram acordados ou despertaram espontaneamente).........

Figura 12 - Idade entre os participantes de grupos diferentes (com cochilos e 59 sem cochilos).

Figura 13 - Pontuação entre os participantes de diferentes grupos (com cochilos e sem cochilos).

Figura 14 - Distribuição dos horários que dormiram e acordaram em grupos diferentes (com cochilos e sem cochilos).

Figura 15 - Horários entre os que cochilam e os que não cochilam durante o dia 61

Figura 16 - Distribuição da pontuação na GDS entre homens e mulheres $\quad 62$

Figura 17 - Distribuição da pontuação na GDS entre os participantes em grupos 62 diferentes (acordar ou não acordar à noite).

Figura 18 - Pontuação na GDS entre os participantes de diferentes grupos 63 (foram acordados ou despertaram espontaneamente).

Figura 19 - Pontuação na GDS entre os participantes de diferentes grupos.......... 63

Figura 20 - Pontuação na GDS entre os participantes de diferentes grupos 64 segundo pontuação no teste do cronotipo...

Figura 21 - Correlação entre horário que dormiu e cronotipo.............................. 64

Figura 22 - Correlação entre horário que acordou e cronotipo.............................. 65

Figura 23 - Correlação entre cronotipos e horário em que dormiram os idosos 65 institucionalizados, estratificadas por gênero: Feminino $(r=-0,25$; $\mathrm{p}=0,275)$ e Masculino $(\mathrm{r}=0,37 ; \mathrm{p}=0,367)$.

Figura 24 - Correlação entre cronotipos e horário em que acordaram os idosos 66 institucionalizados, estratificadas por gênero: Feminino $(r=-0,31 ; p$ $=0,166)$ e Masculino $(r=0,48 ; p=0,228)$. 


\section{Lista de Tabelas}

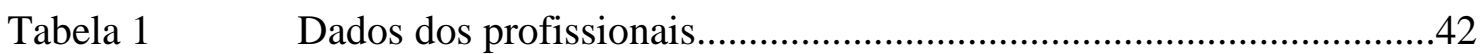

Tabela 2 Perfil sociodemográfico dos residentes..............................................45

Tabela 3 Satisfação com a vida relacionada a domínios..................................47

Tabela 4 Pontuação relacionada a queixas de depressão....................................49

Tabela $5 \quad$ Emissões relacionadas à velhice...........................................................50 


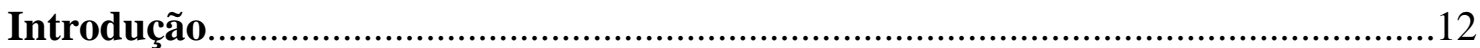

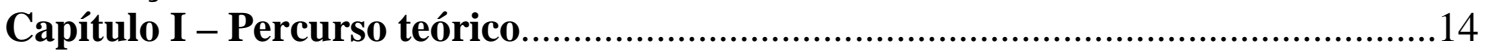

1 - Os ritmos biológicos e o disciplinamento às regras...............................................14

2 - Tratar da velhice entendendo o significado das idades...........................................16

3 - As famílias e as instituições de longa permanência................................................21

4 - A antropologia e a velhice no Brasil.....................................................................26

5 - O objeto de estudo deste trabalho e os Estudos Culturais - Perspectiva crítica e

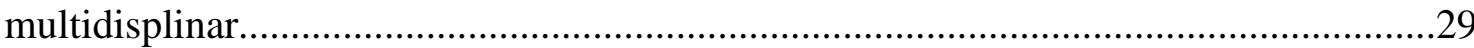

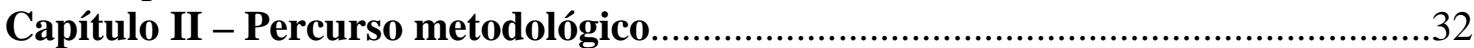

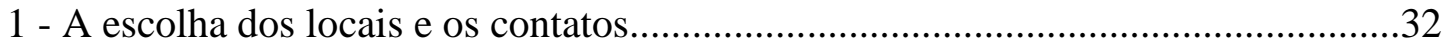

2 - Caracterização das instituições pesquisadas e etapas da aproximação....................32

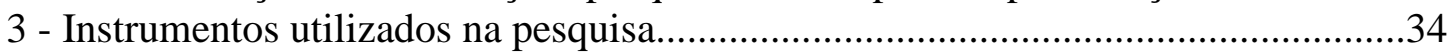

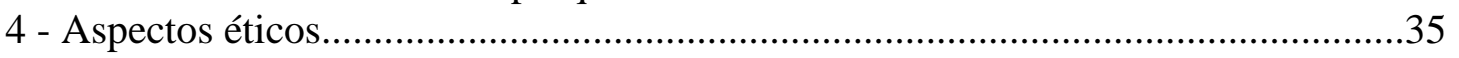

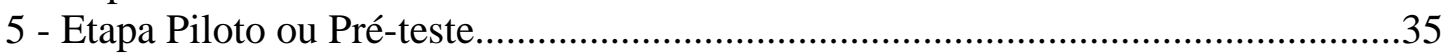

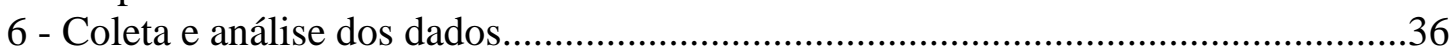

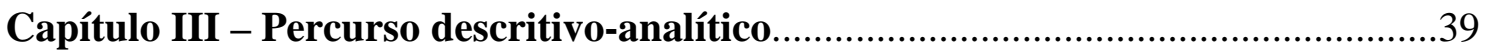

1 - Observação Selvagem - impressões.................................................................. 39

2 - Etapa da aplicação dos instrumentos e da constante observação.............................40

3 - Análise dos dados dos profissionais e seus sentimentos para com os residentes....42

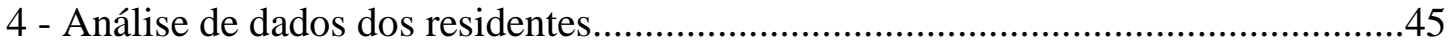

4.1. Dados do Questionário com variáveis Sociodemográficas e Psicossociais....45

4.2. Satisfação com a vida relacionada a domínios...............................................47

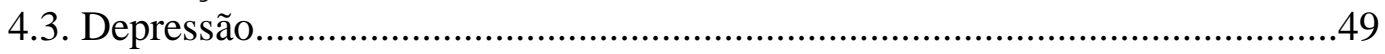

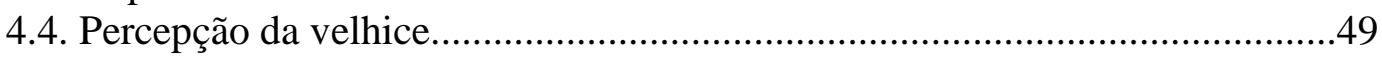

4.5. Determinação de Matutinidade-Vespertinidade............................................50

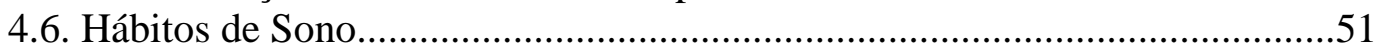

4.7 Apresentação estatística das variáveis depressão, sono e cronotipo................51

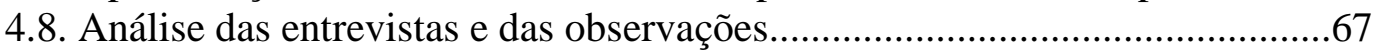

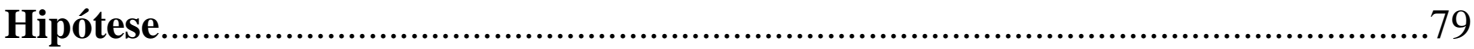

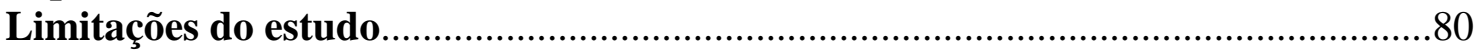

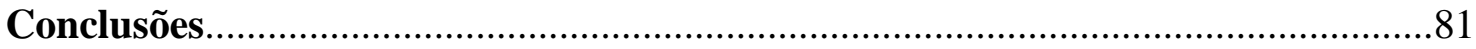

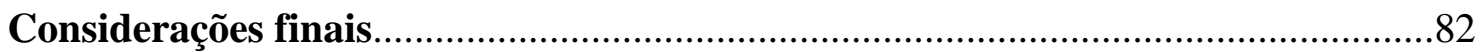

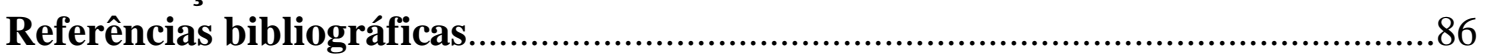

APÊNDICE A - RELATOS DE OBSERVAÇÃO SELVAGEM..................................95

APÊNDICE B - IMAGEM DA APROVAÇÃ̃O PELO COMITE DE ÉTICA.............107

APÊNDICE C - ENTREVISTAS TRANSCRITAS ..................................................108

ANEXO A - CARTA PARA AS INSTITUIÇÕES SOBRE A PESQUISA................126

ANEXO B - CARTA PARA AS INSTITUIÇÕES PÓS COMITÊ DE ÉTICA...........127

ANEXO C - TERMO DE CONSENTIMENTO - IDOSOS ...................................128

ANEXO D - TERMO DE CONSENTIMENTO - PROFISSIONAIS......................129

ANEXO E - QUESTIONARIO SOCIODEMOGRÁFICO........................................130

ANEXO F - ROTEIRO DA ENTREVISTA COM OS RESIDENTES.....................133

ANEXO G - QUESTIONARIO DEDICADO AOS PROFISSIONAIS.....................134

ANEXO H - DIÁRIO DE SONO

ANEXO I - QUESTIONÁRIO IDENTIFICAÇÃO MATUTINO-VESPERTINO...136 


\section{Introdução}

Meu interesse pela área da Cronobiologia, um ramo da Biologia no qual são estudados os fenômenos biológicos segundo o seu perfil temporal, deve-se ao fato de que sempre acreditei que os ritmos e as particularidades de cada pessoa deveriam ser considerados e respeitados. A busca pelos estudos da temática dos tempos sociais e tempos biológicos me aproximou de um grupo de pesquisas nesta área: o Grupo Multidisciplinar de Desenvolvimento e Ritmos Biológicos (GMDRB), da Escola de Artes, Ciências e Humanidades da Universidade de São Paulo, onde várias pesquisas são desenvolvidas para estudar os ritmos biológicos. As diferenças de ritmicidade entre as pessoas e as tentativas de homogeneização de horários e duração de atividades às quais todos nós estamos sujeitos ao longo da vida sempre me preocuparam. Tendo em vista que a maioria das pesquisas no campo dos ritmos biológicos em humanos tem sido realizada com crianças e adolescentes, isto reforçou a minha intenção de estudar pessoas com idade avançada, o que está em linha com a minha recente área de formação, a gerontologia - área multidisciplinar que estuda o processo de envelhecimento humano. Busquei então me aprofundar no estudo dos possíveis impactos que as regras temporais praticadas em instituições asilares pudessem exercer sobre a vida das pessoas que ali residem, sempre mantendo aproximação com os estudos antropológicos e as questões culturais envolvidas.

Essa questão da imposição de horários nos convida a pensar no conceito de tempos sociais e a influência no cotidiano das pessoas, quer estejam em um ambiente institucional ou fora dele e foi o que me levou a buscar alguns estudos sobre tempos sociais para facilitar a minha compreensão do que poderia ser chamado de padrão temporal do cotidiano humano. Dessa forma, encontrei no estudo de Oliva-Augusto (2002) que as mais diferentes teorias sociais qualificam a ordem social moderna como "sociedade do trabalho", exatamente porque reconhecem na categoria trabalho sua dinâmica central. O tempo do trabalho regular, homogêneo, contínuo, é o tempo social nela dominante. Por conseguinte, quaisquer dos outros tempos sociais existentes, referentes a atividades que não são determinantes para sua caracterização, são penetrados por esses traços que adquirem a conotação de identificadores do tempo. Pessoas e instituições são submetidas, fazendo com que a própria definição de ser social - individual e coletivo - sofra, nas palavras da autora citada, "a mediação dos conceitos de trabalho e tempo de trabalho".

Em uma organização social centrada no trabalho na qual esse tempo é predominante, para seus membros em geral é inadmissível a possibilidade de uma nova sociedade onde o trabalho não seja o marcador da divisão do tempo (Braga, 2008). Russell (1935) já estudava 
estas questões do tempo de trabalho e afirmava que o uso do trabalho como argumento de utilidade é produto da civilização e da educação. Tanto que um homem que tenha dedicado toda a sua vida trabalhando longas horas se sentirá entediado quando ficar ocioso Nesta mesma linha, Rolant (1987) sustenta que nós precisaríamos mudar essa visão de que não trabalhar significa necessariamente ficar sem fazer nada, mas sim ter mais tempo para fazer muitas outras coisas que podem até ter mais importância para a vida pessoal ou coletiva, quer os indivíduos estejam vivendo em comunidade ou em instituições asilares. Suponho que as regras para definir as temporalidades em uma instituição asilar são oriundas dessa forma da marcação da divisão do tempo com base no trabalho, ainda que não seja mais aplicável este conceito na fase da vida na qual os residentes na instituição se encontram.

Neste trabalho utilizarei as expressões instituição asilar, asilo, ou instituição de longa permanência para idosos como sinônimos, bem como citarei as pessoas que estão institucionalizadas como residentes na instituição. Não me agrada a expressão paciente, comumente utilizada dentro das próprias instituições. O termo velho para me referir à pessoa que está vivendo a fase da velhice também será encontrado, pois é a forma mais utilizada pelos estudiosos da gerontologia. Penso que sempre que recorremos a eufemismos para nos referir a algo ou alguém, significa que não sabemos lidar com aquela situação e precisamos de artifícios de linguagem.

Este trabalho está estruturado em três capítulos, aos quais denominei percurso: Capítulo I - Percurso Teórico, onde apresento estudos de vários autores que se aprofundaram em temas relevantes para os propósitos desta pesquisa; Capítulo II - Percurso Metodológico onde descrevo os instrumentos, técnicas e procedimentos que escolhemos para selecionar locais e pessoas para coletar os dados; Capítulo III - Percurso Descritivo-analítico, onde apresento os dados obtidos, analiso os discursos e os discuto à luz dos teóricos que fizeram parte desta caminhada.

Os objetivos que nortearam este trabalho foram estudar se a definição dos horários e durações para as atividades cotidianas em instituições asilares pode impactar negativamente sobre os ritmos diários dos residentes, levando em consideração, além dos aspectos cronobiológicos, os aspectos históricos e culturais envolvidos. Além disso, procuro descrever possíveis formas de superar eventuais impactos negativos dessa imposição de horários. 


\section{Capítulo I - Percurso teórico}

1 - Os ritmos biológicos e o disciplinamento às regras

A cronobiologia é uma área do conhecimento que tem como uma de suas metas centrais estudar a dimensão temporal da matéria viva em vários níveis de organização, inclusive o comportamental e o social (Menna-Barreto e Fortunato, 1998). Entre os diversos aspectos dessa dimensão temporal encontram-se os ritmos biológicos, presentes em todos os seres vivos. Concordo com Birth (1999) que, apoiado em pesquisas da cronobiologia, afirma que a homogeneização dos tempos sociais pode causar dessincronização temporal interna o que interfere nos processos corporais e causa uma dessincronização temporal externa. Convém esclarecer que dessincronização interna refere-se à sequência de eventos fisiológicos ao longo do tempo, em geral de um dia, ao passo que a dessincronização externa (MennaBarreto e Díez-Noguera, 2011) diz respeito a desajustes entre eventos ambientais e fisiológicos. Birth (1999) cita que a incompatibilidade entre os ritmos internos e as demandas externas principalmente sobre o momento e a duração do sono pode levar a distúrbios que estão, inclusive, previstos no Manual Diagnóstico e Estatístico IV-TR (APA, 2000) ${ }^{1}$, na categoria para Transtorno do Ritmo Circadiano do Sono que leva a problemas na capacidade de atenção, humor e no próprio ciclo sono/vigília. Segundo estudos de Samis (1968), a organização dos ritmos biológicos, ou organização temporal interna relaciona-se fortemente com a manutenção da saúde dos indivíduos, sugerindo que alterações ou perda desses ritmos seriam fatores associados ao processo de envelhecimento. A dessincronização entre os ritmos pode criar problemas a curto e médio prazos nos ciclos de vigília/sono, humor e desempenho cognitivo nos seres humanos, o que pode levar a problemas de saúde ao longo do tempo.

Buscando fundamentação em Adam (1995) e Elias (1992), encontrei a explicação de que a homogeneização dos ritmos biológicos empurra as temporalidades diferentes em favor do relógio, afastando-se do conhecimento biológico e obscurecendo a capacidade de compreender a interação da natureza e da cultura. Quando homogeneizamos os horários deixamos de considerar as preferências que os indivíduos têm para realizar as atividades diárias.

Segundo estudo de Horne \& Östberg (1976) podemos classificar as pessoas, de acordo com suas preferências, em uma característica conhecida como preferência diária ou cronotipo. Levando-se em conta esta preferência identificam-se três cronotipos básicos; os matutinos, indivíduos que têm preferência em levantar cedo e realizar suas atividades pela

\footnotetext{
${ }^{1}$ American Psychiatric Association. Diagnostic and statisticalmanual of mental disorders. 4th ed. (2000, 622).
} 
manhã, os vespertinos que preferem acordar tarde e realizar suas atividades durante a tarde ou à noite e os intermediários, que escolhem horários intermediários entre os dois extremos. Em um estudo de Andrade, Menna-Barreto e Louzada (1999), o cronotipo apresenta um componente de desenvolvimento ontogenético, ou seja, o cronotipo muda durante o desenvolvimento, do nascimento à velhice. Crianças tendem a ser matutinas, adolescentes mais vespertinos, adultos, intermediários e os idosos tendem a ser matutinos. Porém, conforme já mencionado, podemos encontrar pessoas idosas que não se enquadram neste perfil, pois estão biologicamente sincronizadas em horários incomuns, fugindo à regra da temporalidade da maioria da população. Seus horários, por estarem muito fora do padrão populacional, e por gerarem consequências negativas físicas e psicológicas nos indivíduos, são considerados patologias da ritmicidade circadiana e do sono. Estudo de Ceolim (1999) sobre as modificações na ritmicidade biológica, particularmente aquelas que afetam o sono do idoso, mostram a interferência no bem-estar na senescência. Com o avançar da idade podem ocorrer diferenças significativas na distribuição temporal típica do ciclo vigília/sono e de praticamente todos os outros ritmos biológicos. Segundo Roenneberg et al. (2004) mudanças na concentração e no horário/duração da liberação de muitos hormônios nas pessoas acima de 65 anos, relacionam-se com um sistema circadiano menos robusto, o que pode alterar a estrutura do sono e se potencializa em combinação com uma vida social menos ativa e a baixa exposição à luz. Segundo Geib (2003), ess a s modificações afetam a duração e a qualidade do sono de mais da metade dos adultos com idosos que vivem em suas casas, mas há significativa interferência sobre os idosos institucionalizados, pois $70 \%$ sofrem impacto negativo em diversos domínios da sua vida (Valadares, 1994), já que em uma instituição, os residentes apresentam alta incidência de comprometimento cognitivo, pouca atividade física e necessidade de adaptação ao calendário da instituição, fatores que somados podem influenciar os ritmos diários dos idosos (Bowman, 2004; Mac Rae, 1996; Gordon, 2010). A pouca atividade entre os residentes, comum nas instituições, pode levar a um sono fragmentado, produzindo a sonolência diurna (Voyer et al., 2006); daí gera-se o ciclo vicioso caracterizado por sonolência diurna, cochilos, perda de sono noturno.

Ainda que nos estudos citados não tenha sido tratado especificamente o aspecto temporal, é possível inferir que a determinação rígida de horários nas instituições para idosos pode ter suas raízes nas questões de disciplina impostas principalmente em instituições fechadas, disciplina que é uma das expressões de poder. Entendo que pelo exercício do poder e pelo disciplinamento ao longo do curso de vida, os velhos institucionalizados tendem a naturalizar as normas estabelecidas, o que usualmente ocorre com as minorias em geral. 
Assim, para este estudo, aspectos sociológicos no plano da corporeidade também foram considerados, buscando reflexões sobre a questão do poder e da disciplina, principalmente o que Foucault (2004) denomina docilização dos corpos. Segundo esse autor, a partir desta docilização o corpo humano entra numa maquinaria de poder que define como se pode ter domínio sobre o corpo dos outros, não simplesmente para que façam o que se quer, mas para que operem como se quer, com as técnicas, segundo a rapidez e a eficácia que se determina. Nestas ideias de Foucault é possível traçar um paralelo com a condição dos indivíduos velhos em condição de asilamento e perceber que este aspecto do disciplinamento dos corpos é muito provável se fazer presente, conforme discutirei mais adiante.

Pode ser interessante fazer um paralelo com o que chamamos de culto ao corpo na adolescência e na vida adulta, o que nos leva às vezes a nos tornarmos vítimas de um apego à aparência e uma supervalorização da manutenção da juventude a qualquer custo. Na velhice, entretanto, o corpo passa a ser escondido e esquecido quando num ambiente particular; por outro lado, num asilo se torna disponível para ser manipulado por diversos profissionais. Claro que são situações diferentes, mas no fundo retratam igualmente a nossa condição servil às normas sociais vigentes, ou seja, na juventude o corpo pode ser mostrado, na velhice, ora tem que ser escondido, quando na própria casa, ora o sujeito tem que se despojar de pudor e deixar-se ser exposto.

2 - Tratar da velhice entendendo o significado das idades

Para tratarmos da velhice como uma das etapas da vida precisamos atentar para o fato de que estas etapas foram definidas ao longo da história com motivações várias e não são associadas, como é de se supor, a uma consequência lógica da evolução científica marcada para estabelecer os recortes por idades no desenvolvimento biológico humano (Debert, 1994).

Do ponto de vista biológico, segundo Masoro (1999), o envelhecimento é descrito como um estágio de degeneração do organismo, associado à passagem do tempo, que implicaria em uma diminuição da capacidade do organismo para sobreviver. Para o autor, o problema começa quando se tenta marcar o início desse processo, ou medir o grau desse envelhecimento ou degeneração. O critério mais comum para a definição do envelhecimento, a idade cronológica, é apontado como falho e arbitrário, face à heterogeneidade da população; pessoas com a mesma idade cronológica encontram-se em estágios completamente distintos de envelhecimento, sem contar que nosso próprio organismo envelhece de maneira diferente em relação aos tecidos, como pele, ossos, etc, dependendo de fatores internos e externos aos 
quais a pessoa se expõe. Masoro (1999) denomina esse fenômeno de quebra-cabeças biológico e, realmente querer somente definir o envelhecimento de uma pessoa pela sua idade significa desconsiderar esse fenômeno.

No mesmo sentido podemos citar Bourdieu (1983) quando afirma que, ao tratar da divisão por idades é primordial nos lembrarmos de que essa divisão é uma criação arbitrária. A manipulação das categorias de idades, conforme ressalta Bourdieu no texto "A 'juventude' é apenas uma palavra", envolve uma verdadeira luta política, na qual está em jogo a redefinição dos poderes ligados a grupos sociais distintos em diferentes momentos das fases da vida.

Todavia, ao afirmarmos que as categorias de idade são construções culturais e que mudam historicamente, não significa dizer que elas não tenham efetividade. Debert (2003) afirma que essas categorias representam realidades sociais específicas, uma vez que operam recortes no todo social, estabelecendo direitos e deveres diferenciais no interior de uma população. Além de deveres, distribuem poder e privilégios para determinados grupos sociais, em detrimento de outros, principalmente os mais idosos.

A demonstração de que a periodização da vida implica um investimento simbólico específico, em um processo biológico universal, não está ausente da pesquisa histórica que trata das mudanças ocorridas nas sociedades, principalmente nas europeias. Podemos aqui citar Ariès (1981) mesmo se referindo a outra etapa da vida que não a dos indivíduos dos quais estamos aqui tratando, quando escreve sobre a invenção da infância, que é um dos exemplos mais difundidos de como se deu a construção social das categorias de idade. Ainda seguindo este raciocínio, podemos fazer uma relação com a fase da vida denominada velhice, pois se a modernidade, como mostrou Ariès, assistiu à emergência de etapas intermediárias entre a infância e a idade adulta, assistimos atualmente a uma proliferação de etapas intermediárias de envelhecimento.

Laslet (1989) foi um dos precursores dos estudos sobre o surgimento de uma nova e diferenciada etapa da vida, pois, segundo ele a extensão do curso de vida em alguns anos ou até décadas apresentou alguns desafios, já que este tempo não estava previsto no campo social e precisou ser formulado. Segundo o autor, para utilizarmos este inesperado adiamento da mortalidade que nos permite sobreviver até o limite biológico da vida, era necessário criar uma nova divisão das diferentes etapas da vida, inserindo a terceira idade. Neste momento da vida é que as pessoas experimentariam a realização pessoal, sem obrigações e participando das atividades que somente fossem do seu interesse. Daí, provavelmente, tenham surgido as expressões idade de ouro e melhor idade para identificarem a velhice sem dependência. Do 
meu ponto de vista acho válidas as proposições desse autor, mas também concordo com as restrições apontadas por Debert (1999) de que a criação desse conceito de terceira idade colocou sob a responsabilidade do indivíduo seguir certas prescrições e modelos médicos e sociais para alcançar o sucesso, excluindo, deste modo, aqueles que não conseguem seguir os mesmos modelos. Neste sentido é interessante conhecer como Canguilhem (1978) analisou a busca infrutífera pela normatização da velhice. Para o autor existe uma capacidade inerente ao organismo de fornecer suas próprias normas orgânicas, que ele denomina normatividade vital, só que no caso da velhice, em função da sua heterogeneidade, tais normas orgânicas não levam a essa normatividade. Elas atuariam apenas nas singularidades individuais. Talvez por isso, o autor acredita que um fabuloso aparato parece ter sido criado para artificialmente normalizar o envelhecimento e, por meio dessas normas sociais, gerir a velhice.

Outros autores como Blaikie (1999) e Peixoto (2004) partilham dessa preocupação quando colocam que a classificação da terceira idade esconde a velhice que pode ser acompanhada de dependência e decadência cognitiva, acobertando a sua percepção como problema coletivo e diminuindo a responsabilidade social pelo seu acolhimento.

Analisando as ideias desses autores e tentando relacionar com o local onde realizei minha pesquisa de campo, que são as instituições asilares, para entender se este fato mencionado pelos autores de que a invenção da terceira idade influenciou negativamente a forma como se estruturaram as instituições asilares, não me parece que isso tenha exercido influência relevante. Parece-me sim que este modo de funcionamento sofreu maior influência da herança do modelo baseado na filantropia, o que pode configurar este tipo de assistência como um favor. Deste modelo resultariam as formas de encarar os "favorecidos" como uma categoria excluída.

Sobre esta exclusão, lembro a citação de Elias (2001) em “A solidão dos moribundos" de que a a velhice é um segredo desagradável de se conhecer, explicando daí a criação de formas cada vez mais sofisticadas de negar sua existência. Da mesma forma, negamos o processo de morrer, ao invés de falarmos mais abertamente sobre a morte, tratamos de ocultá-la e silenciar. Para Elias, o processo da morte pode ser compartilhado somente até certo limite, pois se uma pessoa que está prestes a morrer, sente que deixou de ter significado para os outros, e assim a solidão está configurada. A noção de solidão é ampla e manifesta-se de várias formas, como, por exemplo, na exclusão social, criando os "seres invisíveis", dentre os quais, aqueles que estão em instituições asilares, já que suas vidas socialmente não têm significado.

Tendo em vista esta invisibilidade, a importância de reconhecer as vontades dos 
residentes em instituições asilares torna-se ainda maior. Para tanto, é preciso olhar para suas identidades como pessoas e não apenas como corpos que estão naquele ambiente para serem cuidados, independentes dos sujeitos que os possuem. Para ajudar nestas reflexões tomarei como base os escritos de Erwing Goffman (1963) e David Le Breton (2011) entre outros autores que se dedicaram a estas importantes questões sociológicas.

Em nossa sociedade ocidental a velhice é tratada como um estigma. Estigma muito bem descrito por Goffman (1963), ao afirmar que nós estabelecemos meios de categorizar as pessoas e esperar delas determinados comportamentos, atitudes e possibilidades de participação em atividades socialmente importantes; caso contrário, nós as estigmatizamos como seres fora da normalidade e nesta categoria podemos inserir as pessoas velhas, pois nelas o aspecto físico passa a ser um incômodo em certo sentido para as demais categorias etárias, pois a velhice expõe a nossa finitude e a nossa impotência diante dela.

Le Breton (2011) reconhece bem essa questão da estigmatização da pessoa idosa ao afirmar que o envelhecimento marca a escravização do indivíduo que o opõe ao seu corpo e ao mesmo tempo, o torna dependente dele. Ainda citando o estigma que acompanha a palavra velhice, Le Breton lembra que Simone de Beauvoir rompeu um pacto de silêncio ao afirmar que ela própria havia chegado ao limiar da velhice, isto constrangeu muitas mulheres na mesma situação, já que ela nomeou o inominável e gerou um incômodo por expor algo que se procurava negar. Neste sentido Le Breton afirma que o homem da Modernidade combate os traços de sua idade para evitar transgredir a juventude, a sedução, a vitalidade e o trabalho, que são os valores centrais da Modernidade. E o corpo, que para os mais recatados deveria ser escondido, na velhice passa a ser exposto, porém em uma condição desagradável de ser vista, principalmente quando em uma situação de dependência.

Há ainda outro aspecto que precisamos considerar ao pensar em respeitar as subjetividades dos indivíduos em instituições asilares, precisamos atentar para que não se tornem instituições totais, termo utilizado por Goffman (1974), ao defini-las como locais de residência ou trabalho onde um grande número de indivíduos em situação semelhante, separados da sociedade mais ampla, leva uma vida fechada e formalmente administrada. Precisamos pensar maneiras de como fugir dessa lógica e evitar o que esse autor chama de despersonalização do ser humano onde o indivíduo deixa de ser um indivíduo e passa a ser uma peça no sistema da instituição. Pensando nesta questão da instituição total fui verificar em pesquisa realizada sobre instituições para idosos e, segundo o levantamento efetuado em âmbito nacional, $21 \%$ delas são consideradas livres ou abertas, isto é os residentes podem ir e vir quando quiserem, atendo-se apenas aos horários de se recolherem à noite; $50 \%$ são semi 
abertas, os residentes podem sair acompanhados, mas seguem os horários e rotinas da casa e 29\% são fechadas, ou seja, os residentes só saem por alguma necessidade e com acompanhamento (Camarano e Kanso, 2010).

Neste estudo sobre instituições asilares onde proponho me aprofundar na área da cronobiologia, estes dados que apontam para quantos desses locais existem e que tipo de obrigatoriedade de seguir rotinas é praticado, se juntam às questões de corpo, solidão, indivíduo e a imagem da velhice como objetos de estudo indissociáveis. Esta questão da imagem do velho perante a sociedade, descrita por Simone de Beauvior na década de 1970 continua muito atual. Em seu clássico livro “A Velhice”, ela cita que os adultos se comportam como se nunca fossem ficar velhos, pois a decadência física é escancarada à vista de todos, por isto fingimos não ver a imagem que as pessoas velhas propõem para nós e agimos como se a velhice só dissesse respeito aos outros (Beauvoir, 1990). Fica bem a propósito também a frase escrita por Drumond (1990) em "O Avesso das Coisas" de que "os outros enxergam a velhice que se esconde em nós".

Analisando todos estes aspectos da negação da própria velhice, bem como da exclusão e da invisibilidade que negam a individualidade das pessoas, me detenho pensando em como meu objeto de estudo, ou seja, o conhecimento dos aspetos cronobiológicos que pressupõem um estudo das preferências pessoais, poderia influenciar positivamente de alguma forma nesse cenário.

Neste ponto faz-se necessário compreender melhor do que se ocupa a cronobiologia. Trata-se de um campo de estudos dos ritmos biológicos, sendo o mais conhecido o ritmo dito circadiano (do latim circa diem), que se refere ao período de cerca de 24 horas, presente em praticamente todos os fenômenos biológicos, como, por exemplo, os estados de sono e vigília e a complexidade de aspectos envolvidos com esses ritmos. O uso do termo "circadiano" deve ser restrito à descrição de oscilações cujos períodos aproximam-se de 24 horas em condições constantes. Quando observamos oscilações em organismos em vida livre, torna-se necessário usar a expressão "diário" na qualificação dos ritmos encontrados (Marques e Menna-Barreto, 2003). Sabemos que seria importante ser de conhecimento mais difundido que as pessoas podem apresentar ritmos diários diferentes dos estabelecidos, tendo em vista que as diferenças de ritmos entre os lares de origem e a instituição podem causar conflitos temporais. Estes conflitos podem ser passageiros e em curto espaço de tempo a pessoa consegue adaptar-se ao ambiente. Porém, este conflito pode se tornar crônico, constituindo o que podemos denominar agora de atrito temporal, que representa um desajuste temporal crônico (Menna-Barreto, comunicação pessoal, 2016). 
As regras para o funcionamento de instituições para idosos, conforme estabelecido no Estatuto do Idoso, estabelecem a manutenção de padrões adequados de habitação aos residentes, o fornecimento de alimentação e a higiene compatível com as normas sanitárias (Brasil, 2003). Não existem informações sobre as possíveis influências que a imposição de horários rígidos e durações para as atividades podem exercer quando não se observam as possíveis diferenças entre os ritmos biológicos das pessoas atendidas na instituição. $\mathrm{O}$ Estatuto seguiu o que descreve a Portaria 73 que regulamentou esses locais (Brasil, 2001), porém, notamos que as orientações nela contidas referem-se, prioritariamente, às questões do cuidado e da forma de tratamento, não se atendo ao fato de que a instituição asilar é um local para residência permanente.

Em relação ao termo residência permanente, verifiquei no estudo de Camarano (2011) que o tempo médio de residência em uma instituição asilar, até a pessoa vir a falecer é de 5,9 anos para os homens e de 6,7 anos para as mulheres. Visto que a pesquisa foi realizada há alguns anos, suponho que esse tempo de residência atualmente deve ter sido ampliado (em função da aplicação de recursos terapêuticos recentes, por exemplo), o que representa um intervalo significativo de duração de vida. Claro que o fato de a pessoa viver um ano ou viver dez anos na instituição não deveria ser o condicionante para levar em consideração as suas preferências pessoais, mas a citação desse dado reforça que, cada vez mais, a duração de residência deve ser motivo para evitar-se o modelo hospitalocêntrico.

\section{3 - As famílias e as instituições de longa permanência}

Vivemos um momento em que as projeções demográficas apontam para o crescimento do número de idosos, concomitantemente com a mudança na estrutura das famílias o que dificulta às mesmas proverem os cuidados que essa população possa vir a requerer. As famílias de modelo nuclear, ou seja, constituídas por pai, mãe, filhos, estão diminuindo e abrindo espaço para outros arranjos familiares que muitas vezes não comportam mais o cuidado com a pessoa idosa. Segundo Camarano (2011), essas mudanças e a crescente participação da mulher - tradicional cuidadora - no mercado de trabalho, passam a requerer que o Estado e o mercado privado dividam com as famílias as responsabilidades no cuidado com a população idosa. Diante desse contexto, uma das alternativas de cuidados nãofamiliares existentes corresponde às instituições de longa permanência para idosos (ILPIs), sejam públicas ou privadas. Em nosso meio, ainda é comum associarmos ILPI a uma instituição para cuidados de doentes, mas elas não são estabelecimentos voltados somente à clinica ou à terapêutica, apesar de os residentes receberem - além de moradia, alimentação e 
vestuário - serviços médicos e medicamentos. Há vários motivos que podem levar as famílias a optarem pela institucionalização de seu familiar como a pobreza, os conflitos intergeracionais, a saída dos membros da família para o mercado de trabalho e o aparecimento das patologias que vão determinando a sua dependência física, ou a perda de autonomia (Espitia e Martins, 2006). Juntos, todos estes aspectos da vida familiar contemporânea têm gerado aumento expressivo na demanda por este tipo de serviço.

Para fugir um pouco do monótono relato de estatísticas sobre o envelhecimento em nosso país, comum na maioria os trabalhos ligados à gerontologia, decidimos colocar apenas alguns números para ilustrar, sem nos aprofundarmos neles. São Paulo é o estado brasileiro com o maior número de idosos: 5,4 milhões (BRASIL, 2011) e apresenta a maior demanda por instituições asilares para esta população. Uma pesquisa nacional, liderada por Camarano e Kanso (2010), mostrou que 65,2\% das ILPIs são de natureza filantrópica e as particulares somam 28,2\%; já as públicas são a minoria. Em São Paulo concentram-se $34,2 \%$ das instituições, o que corresponde a 1.200 instituições. No Brasil apenas 29,9\% dos municípios contam com esta modalidade de serviço. No levantamento de 2010, $91 \%$ dos leitos eram ocupados por uma população de aproximadamente 110 mil pessoas, o que representava menos de $1 \%$ dos idosos. Após a publicação desta pesquisa, Camarano enfatiza que a situação mudou com muita rapidez e a tendência é de crescimento da procura por este tipo de atendimento à população velha, com ou sem fragilidade. Segundo citado em estudo de Mansano-Schlosser $e t$ al. (2014), se comparado a 2008, em nosso país o número de idosos sendo cuidados por pessoas externas à família dobrará em 2020, mostrando a necessidade de criarmos alternativas para nos adequarmos a este quadro. A preocupação com esse quadro já foi apontada em artigo de Ramos et al. (1987), como um dos trabalhos marcantes para colocar o foco sobre a questão do envelhecimento populacional brasileiro, no qual os autores alertam para a mudança da pirâmide etária, o aumento da expectativa de vida com a possibilidade do aumento de doenças crônicas e a necessidade de políticas públicas voltadas para essa transição epidemiológica.

Há algumas décadas, no final dos anos 1980, os locais para residência de idosos começaram a proliferar e a denominação adotada à época para esses locais era asilo. Etimologicamente, asilo é definido como abrigo, refúgio, acolhimento, porém, segundo Santos e Meneghin (2006), o termo passou a ser considerado não uma possibilidade de cuidados, mas um local de abandono, evidenciando a influência da visão estigmatizada que esta denominação despertava na sociedade. Veras (2002) e Duarte (2004) afirmam que a questão do asilamento em nosso país, ainda tem despertado sentimentos de indignação em 
vários autores que a veem como ação da sociedade, que descarta os indivíduos no momento em que deixam de ser saudáveis e produtivos. A mudança na nomenclatura desses locais, para ILPI, veio como uma das medidas para amenizar esse preconceito.

A Agência de Vigilância Sanitária (ANVISA) define as ILPIs como instituições governamentais ou não governamentais, de caráter residencial, destinadas a domicílio coletivo de pessoas com idade igual ou superior a 60 anos, com ou sem suporte familiar, em condição de liberdade e dignidade e cidadania (Brasil, 2005). Na área da saúde a aprovação da Portaria n. 399/2006, divulga o Pacto pela Vida, consolidando o SUS (Brasil, 2004). Nesta portaria, foram estabelecidas seis áreas prioritárias de atuação, dentre as quais se encontra a saúde do idoso e, entre as diversas ações para que esse pacto se consolide, as instituições destinadas ao asilamento de idosos são uma alternativa, principalmente quanto a pessoa começa a se tornar dependente de cuidados constantes. Segundo a ANVISA, o grau de dependência varia de acordo com as dificuldades de execução de atividades de vida diária pela própria pessoa, conforme descrito a seguir:

- O conceito de indivíduo autônomo se refere à capacidade de uma pessoa de ter poder decisório e controle sobre a sua vida

- Grau de Dependência I - idosos independentes, mesmo que requeiram uso de equipamentos de autoajuda, tais como óculos, aparelhos auditivo, dispositivos de suporte à caminhada;

- Grau de Dependência II - idosos com dependência em até três atividades de autocuidado para a vida diária, tais como alimentação, mobilidade, higiene, sem comprometimento cognitivo ou com alteração cognitiva controlada;

- Grau de Dependência III - idosos com dependência que requeiram assistência em todas as atividades de autocuidado para a vida diária e/ou com comprometimento cognitivo.

Aqui seria interessante fazermos uma reflexão sobre a dificuldade de decisão das famílias, ou mesmo uma decisão do próprio indivíduo pela institucionalização, que normalmente é pautada também por questões que envolvem família e sociedade. A difícil decisão é ainda reforçada pelo fato desse espaço ser considerado somente como provedor das condições objetivas de sobrevivência, tendo ainda a medicalização como propósito (Pestana e Espírito-Santo, 2008). Entendo que nesses locais continua predominando uma tendência da busca da normalidade como ausência de doença o que, conforme Dalgalarrondo (2000) tratase de uma visão utópica, pois se estabelecem critérios socioculturais e ideológicos arbitrários 
da denominada normalidade ideal e passa-se a adotar o binômio saúde-doença como fio condutor de ações.

Dessa forma, ir para uma instituição asilar tende a ser encarado como hospitalizar-se por tempo indeterminado, num lugar para esperar a vida passar. Concordo com a afirmação de Gouvêa (2002), que diz que o ato de viver não é apenas um passar de tempo, mas sim o passar do nosso tempo. Se não percebermos a estrada pela qual estamos caminhando como saber se estamos vivendo?

Partindo dessa questão da vida e da morte, considero interessante colocar aqui também alguns argumentos de um autor da área de ciência e ética (Foddy, 2012), quando estuda as vantagens e a necessidade de morrermos em algum momento, pois o que temos visto são tentativas de retardar ou eliminar os processos de envelhecimento humano. Segundo o demógrafo Vaupel (2010) a ciência médica, não de maneira totalmente voluntária, já atrasou em média, o processo de envelhecimento em dez anos. Comparados às pessoas que viveram no século XIX nós ganhamos dez anos de mobilidade, dez anos sem determinadas doenças e passamos a ter por mais tempo a sensação de boa saúde. Em seus estudos Foddy alerta que, ainda que tecnologias médicas possam gerar um impacto mais decisivo sobre a velocidade do envelhecimento humano, muitos estudiosos colocam várias objeções morais a estas tecnologias, com base nos custos sociais de uma vida mais longa. Ele cita argumentos de alguns filósofos de que cada um de nós é responsável por uma proporção de uso dos recursos do mundo, incluindo alimentação e espaço e que seria uma injustiça para com as gerações futuras se nós não morrêssemos.

Considero estes argumentos muito válidos, mas acredito ser difícil conseguirmos barrar os progressos nessa área, pois, segundo o que o mesmo autor coloca sobre o limite biológico do quanto podemos viver, a expectativa de vida humana continua a crescer somente com a aplicação das tecnologias médicas. Há também que avaliar que se considerássemos que não deveríamos atuar sobre a "natureza" do envelhecimento, seria razoável pensar também que um câncer, ou uma doença cardiovascular não deveriam ser combatidos.

A nossa compreensão da biologia do envelhecimento ainda é bastante jovem e o conhecimento nessa área não é dominado com profundidade. Porém, conforme estudos de Pawelec (2006), sabe-se que já nascemos com todos os genes "prejudiciais", mas nem sempre eles irão se manifestar todo o tempo em todos os tecidos e que podem vir a se expressar mais tarde na vida e não no início, ou mesmo nunca. Isto é, alguns genes não estão ativos na síntese de proteínas, a menos que eles estejam em partes específicas do corpo, em determinadas fases do desenvolvimento. Esta é uma das explicações sobre porque os seres 
humanos tendem a ficar mais doentes à medida que envelhecem e estas doenças, do ponto de vista biológico, constituirem em grande parte o que se considera ser a velhice.

Parte do surgimento de doenças deve-se a um esgotamento do sistema imunológico que fica mais frágil com o avanço da idade, por volta dos 80 anos, fazendo com que nosso corpo seja menos capaz de repelir as infecções (Pawelec, 2006) e que permite o acúmulo de radicais livres, que são moléculas instáveis e que apresentam um elétron que tende a se associar de maneira rápida a outras moléculas de carga positiva com as quais pode reagir ou oxidar.

De acordo com a versão de Harman (2006), os radicais livres entram no corpo, não só a partir do ambiente externo, mas também como um produto secundário da respiração essencial, o processo por meio do qual as nossas mitocôndrias produzem energia a partir de alimentos e de oxigênio. Estes radicais livres provocam o que se chama de estresse oxidativo que leva à morte celular. De acordo com Harman (2006) e Lapoint (2010) esta acumulação de danos é o processo principal que provoca os sintomas de envelhecimento.

A razão pela qual nós envelhecemos, então, é em parte porque não conseguimos criar defesas suficientes fazendo com que nossos corpos se enfraqueçam com o passar do tempo. Uma alta taxa metabólica tem sido associada em estudos da evolução a um estilo de vida ativo, mas que também produz mais radicais livres endógenos. E, segundo Olshansky et al. (2002), essas falhas da evolução são resultados previsíveis da natureza essencial do processo seletivo, ideias que são consenso entre biólogos estudiosos do envelhecimento humano. A palavra falhas foi colocada em evidência porque acreditamos que atribuir qualidade falhas ao processo de evolução das espécies pode dar margem a interpretação de que há um sujeito controlador do processo. Cabe aqui ressaltar também se trata de uma proposta desse autor, a qual não pode ser entendida como causa fundamental ou essencial do processo de envelhecimento, pois, se ao invés do sistema imunológico fosse o sistema nervoso, o cardiorrespiratório ou outro, provavelmente o mesmo efeito seria observado.

Por outro lado, e para deixar ainda um ponto de discussão, trago o argumento de Linch (2004), que afirma que o estresse oxidativo não é somente danoso, mas também parece agir contra a formação de vários tipos de câncer, de forma que células envelhecidas oxidadas constituem uma barreira no corpo que interrompe a replicação descontrolada dos tecidos. Então, se a senescência previne o câncer, está aí outro argumento pelo qual poderia ser alegado que ao longo do processo de evolução ocorreu um equilíbrio de características para promover a longevidade. Certamente esses pesquisadores e estudiosos buscam reforçar a teoria biológica do envelhecimento, mas sabemos que existem inúmeros fatores sociais que 
influenciam a experiência da velhice, portanto, cabe aqui mencionar algumas considerações de Simone de Beauvoir (1990) ao situar a velhice como experiência histórica. Diz ela que embora a velhice seja, na sua qualidade de destino biológico, uma realidade trans-histórica, ainda assim subsiste o fato de que este destino é vivido de maneira variável, segundo o contexto social. Para a autora, o modo como uma sociedade trata a velhice revela o sentido de toda a vida anterior. Ela questiona que, se ao considerarmos o indivíduo como um todo e se ele começa a declinar depois de ter atingido o apogeu, onde podemos situá-lo se o declínio intelectual e o físico não evoluem na mesma velocidade? O indivíduo pode sofrer perdas morais consideráveis antes que tenha início sua degradação física; pode, ao contrário, suceder que no decurso desta decadência ele consiga importante ganho intelectual. A qual deles atribuiremos mais valor? São questões importantes que ela propõe, pois de fato não se pode atribuir ao envelhecimento um caráter absoluto porque não é possível conceituar a velhice de modo único, tendo em vista a pluralidade de experiências que ela encerra, o que traz alguns conflitos. Conflitos que não devem ser eliminados, pois servem como elementos de mudanças.

\section{4 - A antropologia e a velhice no Brasil}

Não existe uma definição clara de como se dá a transição da vida adulta jovem para a fase denominada velhice, última fase do curso de vida. Certamente a idade cronológica não é um determinante, visto que os processos biológicos que acompanham o envelhecimento, a aparência física, até o aparecimento de doenças crônicas são, segundo Camarano (2011) dependentes das condições sociais, econômicas, regionais, culturais, étnicas e também de gênero. Mesmo considerando que esta questão da idade cronológica não seja um marcador ideal, vejo como um fator importante a ser considerado, o espectro de idades que compreende a chamada velhice, quando as instituições abrigam pessoas em faixas etárias muito diferentes que passam a conviver num mesmo ambiente e seguindo a mesma rotina. Concordo com a opinião de Camarano (2011) quando ela cita que legalmente no Brasil define-se como idosa uma pessoa a partir dos 60 anos, conforme consta no Estatuto do Idoso e na Política Nacional do Idoso, ou seja, aí se incluem desde as pessoas com 60 anos de idade até os centenários e sabemos que quanto mais velhos formos mais diferentes seremos entre nossos pares. Segundo a autora, essa heterogeneidade é acentuada no decorrer da vida das pessoas pelas suas diferentes trajetórias que foram marcadas pelas desigualdades raciais, sociais e de gênero presentes em nossa sociedade.

Vejo bem essa questão de gênero aparecendo entre as pessoas que fazem parte do meu 
estudo, pois em ampla maioria são as mulheres que têm sido "colocadas" em instituições, as quais nasceram nas primeiras décadas dos anos 1900 e são em geral pessoas com baixa escolaridade e sem muita condição de criticidade e habituadas às condições que lhes foram impostas ao longo de suas vidas.

Acredito que a nossa despreocupação em investir na melhoria das instituições asilares seja em grande medida influenciada pela nossa negação da velhice, mas há uma dificuldade cultural, citada por Debert (2012), que me parece bastante pertinente. Diz ela que, da mesma forma que se acreditava ser a mãe a única pessoa responsável pelo cuidado do filho, hoje acreditamos que os velhos gostam de viver com os filhos, o que nem sempre é verdade, ou ainda, que gostam de viver na própria casa mesmo em condições de dependência e cuidados constantes. Então, acabamos por nos tornar vítimas dessa nossa omissão, pois a realidade é que não termos mais modelos de famílias com estrutura para receber seus velhos, nem condições de gerenciar sua permanência no domicílio quando dependentes.

Neste aspecto considero muito interessantes as reflexões que Debert (2012), uma antropóloga estudiosa das questões da velhice, nos propõe ao falar sobre a dignidade na idade avançada. Ela diz que nós comemoramos o aumento da expectativa de vida, mas não nos preocupamos em criar espaços para receber a velhice com dependência e, segundo ela, tratase de um grande desafio para a nossa sociedade criar instituições que ajudem a manter a dignidade humana na velhice. Para analisar a questão da qualidade das instituições para pessoas velhas gosto de uma analogia que a autora faz entre escolas infantis e estas instituições. Para tanto ela cita o fato de que há pouco mais de três décadas, se uma mãe precisasse deixar seu filho em uma creche ela se sentia culpada e era considerada desnaturada, pois aqueles locais eram tidos como "depósito de crianças". Com o tempo as creches foram sendo reformuladas e mudaram. Hoje, se uma mãe não coloca seu filho de dois anos numa escola infantil, ela pode ser acusada de estar impedindo o desenvolvimento da sociabilidade da criança. Ou seja, em pouco tempo a interpretação da mesma situação se inverteu. Fazendo um paralelo com as instituições para velhos, podemos inferir que não seria considerado um abandono ou desprezo deixar nosso familiar numa instituição, se nesse local ele fosse considerado um residente e que tivesse voz para dizer como gostaria de ser tratado, que não fosse infantilizado e nem considerado simplesmente um objeto de cuidados à espera da morte. No entanto, ainda segundo Debert (1999), em pouco tempo a geração denominada baby boomer que protagonizou o movimento da contracultura e o feminismo, tanto nos EUA, como em países europeus influenciando a juventude de muitos outros países, estará entrando na fase da velhice. Possivelmente o nível de exigência deste público influenciará positivamente a 
reformulação destas instituições. Baby boomer é a denominação atribuída à geração que nasceu entre os anos de 1946 e 1964, em diversos países envolvidos na segunda guerra mundial. A alta taxa de natalidade verificada nestes países com os soldados voltando da guerra explica o fenômeno baby boomer, termo que se generalizou em diversos países, inclusive no Brasil. Esta geração é caracterizada por ter sido protagonista de grandes mudanças de comportamento que marcaram os anos 1960 que são definidas como movimento de contracultura. Segundo Pedreira (1986) contracultura é um conjunto de atitudes de rebelião da juventude como forma de contestação e enfrentamento diante da ordem vigente, seja ela na área política, econômica e também nas estruturas das famílias. Desta forma, acredito que podemos inferir que os protagonistas destas mudanças comportamentais, ao entrarem na fase da velhice terão melhores condições de criticar e exigir locais de convivência mais adequados e dignos, mesmo na velhice com dependência. Existe uma ideia amplamente difundida segundo a qual os jovens são revolucionários e os velhos reacionários, o que leva a uma crença que retroalimenta esta ideia ${ }^{2}$, por isto espero que estes "novos" velhos venham com capacidade crítica para exigir mudanças na natureza das instituições asilares que eles escolherem para viver.

Essas questões do isolamento asilar, me levaram a pensar sobre o que relata o educador Paulo Freire (2008), em relação à vida no exílio. Foi possível estabelecer uma semelhança entre o estar exilado e a vida do residente num asilo para velhos, no aspecto do encontrar-se ali por razões alheias à sua vontade. Freire dá o nome de "realidade de empréstimo" ao momento presente e relata o dilema de lidar com sentimentos, recordações e visão do mundo acumulados, tendo que viver numa realidade de empréstimo. Acredito que, assim como no exílio, as pessoas precisam encontrar formas de viver numa cotidianidade estranha, quando são colocadas em uma instituição asilar.

Por outro lado, conforme analisado por Clos (2010), a vida numa instituição asilar pode representar para muitas pessoas uma possibilidade de socialização que muitas vezes não ocorria nos lares de origem. Ou seja, a institucionalização passa a dar-lhes uma melhor condição e qualidade de vida. Em minha opinião, o que precisamos é que esses locais estejam cada vez mais preparados para nos receber, pois temos que considerar a possibilidade de nós mesmos decidirmos por essa solução no futuro.

Por isto, acredito ser necessário traçar o perfil do indivíduo que ingressa nessas

\footnotetext{
${ }^{2}$ Sobre o caráter conservador dos mais velhos cito como contraponto o sociólogo Lewis (1993), "Porque almocei meu pai" LEWIS, R. Porque almocei meu pai. São Paulo: Companhia das Letras, 1993.
} 
instituições, considerando vários aspectos, dentre eles, respeitar suas particularidades em termos de ritmos biológicos e, de acordo com essas variabilidades, implementar uma forma de atendimento adequado, considerando as regras estabelecidas no ambiente. Pensando nestas regras, não só as temporais, mas todas as necessárias para o funcionamento de uma organização Durkheim (1972) analisa a necessidade da existência de regras quando ele aborda o aspecto interação social entre os indivíduos que integram uma coletividade. $\mathrm{O}$ autor chama de fatos sociais as maneiras de agir e pensar que exercem forças sobre as pessoas e as obrigam a se adaptarem às regras, o que explica o caráter conservador das instituições por essência e a resistência a mudanças que podem abalar a ordem vigente. Ele afirma isto, não por ser ele próprio conservador, mas por enxergar que o ser humano necessita sentir-se seguro e protegido e que, quando não percebe regras claras, pode desestabilizar-se. Trazendo estas ideias para o contexto das instituições asilares, concordo que elas precisam ter suas regras de funcionamento para dar estabilidade aos profissionais e aos residentes. Deixo claro que não são as regras de funcionamento da organização o meu objeto de estudo, mas sua expressão nas rotinas, ou procedimentos adotados, os quais devem sim ser constante alvo de mudanças e flexibilização quando necessário.

Porém, para estudar possíveis mudanças e, considerando o ponto de vista cronobiológico, tenho presente que, segundo Schwarz (2003 apud Tomasini e Alves, 2007) é necessário considerar também a influência do ambiente sobre as pessoas, pois à medida que as pessoas envelhecem, em geral a sua competência para lidar com novas situações diminui e as mudanças ambientais passam a exercer uma pressão maior sobre seu comportamento, ainda que esta pressão esteja mascarada pelo aparente estado de calma nestes ambientes. Este estado de calmaria é bem evidenciado pela constância dos cochilos diurnos, que além de serem favorecidos pela rotina empobrecida, também podem denotar algum distúrbio de sono entre os residentes, como também podem ser resultado das duas coisas. No caso de distúrbios de sono, os estudos de Van Someren (2010) o levaram a afirmar que a sua incidência é fortemente aumentada em idosos, tanto os saudáveis quanto os com comprometimento cognitivo. São alterações no sistema de temporização circadiana, relacionadas com a idade que parecem contribuir fortemente para estes problemas. Acreditamos haver a necessidade de um estudo que considere a complexidade dos aspectos envolvidos com esses ritmos. Assim, levando-se em consideração este universo ainda pouco explorado, nós pretendemos estudar com mais profundidade a vida dessas pessoas que se encontram em instituições asilares e entender a influência que a definição de regras temporais mais ou menos rígidas desses ambientes tem exercido sobre elas. 
5 - O objeto de estudo deste trabalho e os Estudos Culturais - Perspectiva crítica e multidisplinar

Para localizar este trabalho de pesquisa no campo dos Estudos Culturais valho-me da explicação encontrada em Veiga-Neto (2000) que afirma ter este campo, do ponto de vista metodológico, duas tendências: a primeira, mais voltada à etnografia, principalmente no que concerne o estudo de populações urbanas e dos chamados grupos minoritários, envolvendo questões de raça, etnia e gênero; a segunda tem sido dedicada às análises textuais envolvidas mais com o estudo da comunicação de massas e da literatura produzida por e para as classes populares. Desta forma, penso ser possível incluir o estudo etnográfico das populações que vivem em instituições asilares como uma minoria que pode ser abrigada no campo de investigação dos Estudos Culturais, por meio da Cronobiologia, que, da mesma forma que os Estudos Culturais, teve sua expansão a partir da segunda metade do século XX. O desenvolvimento da Cronobiologia ao longo desses anos está relacionado à elaboração de um conjunto de conceitos gerais que permitem compreender os organismos e suas interações com o meio, do ponto de vista temporal. Sendo uma área do conhecimento recente, nasce comprometida com a multidisciplinaridade, portanto, contraria a quem vê na especialização crescente a única possibilidade de progresso do conhecimento. Segundo Marques e MennaBarreto (2003), a cronobiologia provoca reflexões sobre a organização temporal da sociedade, desde a escola até a linha de montagem, mostrando eventuais efeitos contraditórios ou mesmo francamente adversos e propondo horários de atividades mais compatíveis com nossos ritmos biológicos. De um ponto de vista mais amplo, a cronobiologia coloca em relevância toda a questão da adaptação do organismo a temporizações impostas pelo ambiente.

Os Estudos Culturais são caracterizados por sua dimensão multidisciplinar e, do ponto de vista teórico, resultam da insatisfação com os limites de algumas disciplinas, propondo, então, a multi, a inter e a transdisciplinaridade (Escosteguy, 2008). Sob essa ótica, podemos localizar este trabalho de pesquisa, transitando pelas diversas dimensões e disciplinas envolvidas na questão da temporalidade dos sujeitos. Baptista (2009) refere-se aos Estudos Culturais como sendo marcados pela desestabilização das fronteiras, seja das Humanidades ou das Ciências Sociais, num processo em contínuo movimento e procurando revelar discursos marginais, não oficiais, daqueles que não têm voz. Para alguns autores, como por exemplo Reinberg (1977), a cronobiologia tem seu objeto de estudo centrado na contestação do conceito de homeostasia, o que pode se traduzir por confrontar o conceito de normalidade, pois considera que o normal de um organismo é o movimento, a oscilação e não o equilíbrio 
ou a homogeneidade (Menna-Barreto, 2004), portanto, transcende os limites da biologia e adentra em outras disciplinas, pois se ocupa de estudar a influência da homogeneização da temporalidade no comportamento das pessoas.

Estou propondo aqui um trabalho de pesquisa com um grupo excluído e é pelo caminho da interdisciplinaridade dos Estudos Culturais que pretendo pautar este estudo sobre a temporalidade nas instituições para velhos, buscando ultrapassar as fronteiras da biologia e adentrar nos aspectos sociais, psicológicos, ambientais e culturais dessa população que vive à margem da sociedade, observando-a, ouvindo-a e sugerindo mudanças, se necessário. O que vai ao encontro de uma característica na análise praticada pelos Estudos Culturais, que, segundo Pina (2003, in Baptista, 2009), consiste no compromisso cívico e político de estudar o mundo, de modo a poder intervir nele com mais rigor e eficácia, construindo um conhecimento com relevância social. Outro aspecto dos Estudos Culturais a ser observado é que sempre requerem um posicionamento sobre o que se fala, de onde se fala e com que objetivo se fala (Barker, 2008).

Por fim, considerando que os Estudos Culturais se caracterizam por articular simultaneamente inquietações teóricas com preocupações concretas, posso localizar minha pesquisa nestas duas frentes quando se pensa na cultura dos asilos para idosos (teoricamente) e como criar vida nestes locais (na prática). 


\section{Capítulo II - Percurso metodológico}

1 - A escolha dos locais e os contatos

Como critério de seleção dos locais para a realização da pesquisa de campo levei em consideração que, como pesquisadora, deveria estabelecer familiaridade com os membros do grupo. Segundo Richardson (1999), esta é a condição para o desenvolvimento satisfatório de uma pesquisa qualitativa. Com esta premissa da busca de locais em que eu percebesse maior possibilidade de inserção, após algumas visitas e tentativas de contato com vários locais, decidi que a pesquisa seria desenvolvida em uma instituição de longa permanência para idosos localizada na zona leste do município de São Paulo. Em suas quatro unidades a instituição atende vários tipos de complexidade, compreendendo residentes com independência, isto é, que possuem capacidade de realizar atividades sem auxílio; residentes com autonomia, conceito se refere à capacidade de discernimento e tomada de decisão e pessoas com demências em diversos estágios, que são a maioria.

A segunda instituição em que realizei a pesquisa foi uma casa de repouso localizada na zona sul da cidade de São Paulo. Como tive a oportunidade de adentrar ao ambiente em função de um pedido para que eu aplicasse atividades de estimulação cognitiva em residentes diagnosticadas com a Doença de Alzheimer, solicitei autorização à proprietária do local para ali realizar a minha pesquisa. Após levar a carta de apresentação do orientador recebi a indicação para me aproximar das residentes que estavam com a cognição razoavelmente preservada. Digo razoavelmente, pois a maioria tem Doença de Alzheimer diagnosticada, mas várias se encontram no estágio inicial da doença.

Conhecer este novo ambiente foi importante para complementar minha pesquisa, pois me permitiu visualizar algumas aproximações e distanciamentos entre as duas instituições e entre as suas seis unidades.

2 - Caracterização das instituições pesquisadas e etapas da aproximação

A primeira instituição foi inaugurada em 2010 e atualmente possui quatro unidades. Após a inauguração de três unidades, a administração começou a receber a demanda para atender pessoas interessadas em quartos individuais, com espaço para os próprios pertences e televisão, desta forma, a quarta unidade foi inaugurada para um público com poder aquisitivo maior. Na unidade que oferece acomodações individuais o valor da mensalidade é de cerca de dez salários mínimos, enquanto nas unidades com quartos que acomodam de três a seis residentes a mensalidade varia entre quatro e seis salários mínimos. Segundo dados coletados em 08 de abril de 2015, ao todo são atendidos 85 residentes, sendo 20 homens e 65 mulheres. 
Trabalham nas quatro casas 48 funcionários, sendo: cinco auxiliares de limpeza, quatro auxiliares de cozinha, 36 auxiliares e técnicas(os) de enfermagem e três enfermeiras(os). A quantidade de funcionários é relativamente alta, mas necessária para atender a maioria dos residentes com alto grau de dependência e baixa autonomia. As atividades extras oferecidas aos residentes são musicoterapia e arte terapia, que acontecem esporadicamente.

Estive duas vezes na administração desta instituição e fui recebida pela proprietária, a qual me apresentou o administrador geral da casa, que foi o intermediador com as unidades a partir de então. A zona leste está entre os três distritos com o maior índice de idosos por habitante, existindo 20 pessoas com mais de 60 anos para cada 100 moradores (Brasil, 2011), o que pode explicar a grande demanda por este tipo de serviço.

Levei uma carta de apresentação do orientador (Anexo A) e expliquei minhas intenções na pesquisa, pois é muito comum a gerência se preocupar com uma possível investigação com fins de identificar falhas. No caso, ela se mostrou prontamente receptiva, gostou da ideia de me receber e até pediu para que, após a pesquisa, eu pudesse pensar e propor melhorias na instituição sugerindo a diversificação de atividades para os residentes. Atualmente ela oferece majoritariamente serviços de cuidadores. Nesta visita ele me mostrou as dependências de todas as casas: cozinha, almoxarifado, lavanderia, despensa, quartos, postos de enfermagem, residentes acamados, locais de armazenamento de medicamentos, locais de refeições e câmeras de monitoramento.

Na segunda vez em que lá estive, foi para iniciar propriamente os trabalhos, não diretamente com os residentes, mas utilizando uma técnica denominada por Altman (1974) Observational study of behavior: sampling methods, que em português denominamos Observação Selvagem (tradução livre). Ao utilizar esta técnica de observar comportamentos o pesquisador precisa considerar os dois seguintes aspectos: a) quais indivíduos observar e quando; b) estabelecer uma regra de gravação do comportamento observado. Nós escolhemos a regra de observação denominada "ad libitum”, a qual não tem restrições sistemáticas sobre o que e quando é gravado. Assim, o pesquisador observa os comportamentos e registra o que considera relevante no momento. Porém, Altman (1974) alerta para o fato de que este tipo de abordagem muitas vezes influencia a observação, pois nem sempre o pesquisador consegue manter neutralidade em relação ao ambiente, mas nós a escolhemos por ser uma excelente maneira de fazer observações preliminares e, talvez, seja a única maneira em que eventos raros podem ser observados.

Em outra carta dirigida à instituição (Anexo B), explicamos esta etapa e recebemos o aval do administrador para iniciar quando e onde eu preferisse e para dar continuidade à 
pesquisa com os residentes. A forma de registro foi anotação manual em caderno que constituiu o meu diário de campo durante todo o tempo de pesquisa. A técnica da observação selvagem foi utilizada somente nessa primeira instituição, tendo em vista que o meio de aproximação propiciou sua aplicação.

A segunda instituição escolhida para fazer parte desta pesquisa localiza-se no na zona sul da cidade de São Paulo, foi fundada em 2008 e possui duas unidades na mesma rua. Um diferencial desta instituição é o fato de atender somente pessoas do sexo feminino, todavia, não tem restrições em receber visitas masculinas. $\mathrm{O}$ critério de alocação das residentes nas unidades se dá por existência de vagas e em ambas existe um espaço destinado a atender tanto as mulheres com independência e autonomia, quanto as dependentes de baixa e média complexidade (grau de dependência I e II); em ambiente separado são colocadas as residentes com maior complexidade (grau de dependência III). Esta instituição ocupa uma casa com quintal e que foi adaptada de residência familiar para a casa de repouso, que é bem simples e seus quartos contêm até seis camas. Trata-se de um sobrado e várias residentes dormem na parte superior, mesmo tendo dificuldade de locomoção. No horário em que as residentes precisam ir dormir muitas delas são quase "puxadas escada acima" por duas atendentes. O valor da mensalidade é de aproximadamente 2,8 salários mínimos, relativamente baixo se comparado à outra instituição pesquisada. Atualmente ali residem 49 mulheres, distribuídas nas duas unidades e trabalham 14 profissionais ao todo, número relativamente baixo, em face da demanda. Dessas 14 profissionais, duas são enfermeiras, três auxiliares de enfermagem, cinco atendentes de enfermagem, duas ajudantes de lavanderia e duas cozinheiras. A casa possui uma terapeuta ocupacional contratada que trabalha todos os dias úteis, meio período em cada unidade.

\section{3 - Instrumentos utilizados na pesquisa}

- Questionário sociodemográfico (Anexo E) para traçar o perfil dos participantes: idade, gênero, escolaridade, renda, tempo de entrada na instituição, suporte familiar. Com parte deste instrumento consta uma escala para analisar tendência de idosos à depressão. Tal escala, a Geriatric Depression Scale - GDS, foi descrita por Yesavage et al. (1983) contendo 30 itens. Neste trabalho utilizei a versão reduzida, contendo 15 questões (GDS15), elaborada por Sheikh e Yesavage (1986) que incluiu os itens que mais frequentemente se correlacionavam com o posterior diagnóstico de depressão. A vantagem de se usar a versão reduzida, desde que atenda aos propósitos da pesquisa, é que o tempo necessário para a sua aplicação é menor.

- Roteiro-mestre para orientar as entrevistas com os residentes a serem gravadas (Anexo F). 
- Questionário aplicado aos profissionais (Anexo G).

- Protocolo Diário de Sono, elaborado e validado pelo Grupo Multidisciplinar de Desenvolvimento e Ritmos Biológicos do Instituto de Ciências Biomédicas da Universidade de São Paulo - ICB, USP (ANDRADE,1991; WEBB \& BONNET,1978), adaptado por Andrade (1997) (Anexo H).

- Questionário Horne-Östberg (1976), internacionalmente utilizado para avaliação de preferências diurnas para a realização de atividades e identificar os chamados cronotipos do espectro matutinidade/vespertinidade, aplicado no Brasil por Benedito-Silva et al. (1990) (Anexo I).

\section{4 - Aspectos éticos}

O projeto de pesquisa foi submetido ao Comitê de Ética em Pesquisa em Seres Humanos - CEP da Escola de Artes, Ciências e Humanidades da Universidade de São Paulo tendo sido avaliado sob os aspectos éticos e legais da legislação envolvida, em especial a Resolução 196/1996 do Conselho Nacional de Saúde. O CEP aprovou a pesquisa em 28 de novembro de 2014, sob o número 38855714.9.0000.5390, conforme imagem mostrada no Apêndice B.

A identidade dos residentes e dos profissionais que participaram desta pesquisa está mantida em sigilo, conforme compromisso estabelecido no item Confidencialidade do Termo de Consentimento Livre e Esclarecido (Anexos C e D).

\section{5 - Etapa Piloto ou Pré-teste}

Para validar os instrumentos inicialmente escolhidos para a pesquisa realizei um estudo piloto com dois residentes, um homem e uma mulher de unidades diferentes. Apliquei os protocolos e gravei as entrevistas com o objetivo de avaliar a duração da atividade, a aceitação do método e o grau de dificuldade de aplicar os protocolos.

Após o pré-teste percebi que o questionário sociodemográfico deveria ser reduzido, pois estava muito longo, tornando-se cansativo. Reduzi então o número de questões relacionadas a vários domínios da vida do residente que estavam sendo explorados na entrevista gravada. Além disso, tive um problema com a família de uma mulher que participou dessa etapa, pois quando ela mostrou a cópia do Termo de Consentimento assinado e comentou sobre a pesquisa com um familiar, este se dirigiu à gerência com uma reclamação, pedindo o cancelamento da entrevista, já que a instituição não deveria ter sugerido a participação da mãe sem pedir consentimento à família. Em vista desse acontecimento 
preparei um comunicado dirigido aos familiares, que foi enviado pelo gerente da instituição, por meio eletrônico, para evitar futuros problemas. Esse fato também foi importante para me deixar atenta a estas questões de família, pois percebi que alguns familiares têm receio do quê será revelado pelo residente. Há também os que nada temem, mas se preocupam que a entrevista possa provocar algum constrangimento ou afetar emocionalmente seu familiar. Porém, em geral o que ocorre é que os residentes ficam contentes em poder conversar com uma pessoa externa ao ambiente e não se sentem constrangidos com a entrevista.

\section{6 - Coleta e análise dos dados}

Como o objetivo neste trabalho consistiu em analisar alguns aspectos da determinação de horários no cotidiano e o processo de adaptação dos residentes em ILPIs, o método adotado foi pesquisa exploratória-descritiva com análise qualitativa dos dados. Uma das técnicas foi a observação participante, segundo proposta de Malinowski (1978), considerado o precursor da técnica. Ao ser um observador participante, pressupõe-se ter um olhar cuidadoso com o nosso objeto de estudo (local e pessoas), pois, segundo o autor, cada organização ou instituição tem sua funcionalidade que muitas vezes foge ao nosso entendimento. Um meio para permitir esta observação foi aplicar os protocolos no próprio local onde as pessoas passam o dia, o que favoreceu observar a rotina de trabalho diário, os detalhes dos cuidados, as refeições servidas e também as simpatias e as animosidades, denominadas por Malinowski imponderáveis da vida real. O mais profundo mergulho na técnica da observação participante seria eu conseguir "ser um deles", ou seja, ser mais que uma observadora. Para isto o ideal seria estar presente na qualidade de residente, o que tornaria os participantes menos objeto de pesquisa para se tornarem pessoas interagindo com o objeto de estudo. Por isto, minha intenção inicial era me integrar como residente por certo período de tempo no primeiro local escolhido para minha pesquisa. No início da pesquisa minha solicitação foi bem recebida pelo gerente local que era meu contato facilitador, porém, meu intento acabou não se concretizando, conforme detalhes que se encontram descritos no item Limitações do estudo. Em relação a este aspecto do acesso, concordo com Spradley (1980 apud Correia, 2009) ao afirmar que para iniciar uma observação temos que ter os três elementos, local, atores e atividades, mas ter acessibilidade é primordial para observar, registrar e analisar os dados etnográficos. Sem facilidade de acesso, o trabalho pode sofrer prejuízo. Felizmente, na segunda instituição em que a pesquisa foi realizada tive acesso ao local, contudo, ali não foi possível executar meu plano de viver como um deles porque não há espaço nem para as residentes. 
Para aplicar a técnica da entrevista semiestruturada gravada, segui um roteiro contendo tópicos orientadores (Anexo F), que diziam respeito a quatro grandes temas: 1) rotina antes do ingresso; 2) tempo de residência e forma de ingresso; 3 ) horários sociais (rotina) na instituição, sono, apetite, etc; 4) rotina ideal (propostas) e o 'passar do tempo'. A análise do material textual resultante da transcrição das entrevistas com os participantes foi realizada por meio do método da Análise do Discurso (AD) proposto por Michel Pêcheux (2002) que o formulou na década de 1970 e foi trazido ao contexto brasileiro por Orlandi (1999). Segundo a autora, o objeto da AD é o discurso, ou seja, interessa-se por estudar a "língua funcionando para a produção de sentidos". Isto permite analisar unidades além da frase, ou seja, o texto em movimento.

Pêcheux (2002) parte do pressuposto de que o diálogo e a discursividade se caracterizam pelos sentidos construídos a partir dos agentes que interagem. Ou seja, um discurso está relacionado com o contexto histórico e social de quem o profere, o que inclui como condição básica para o acontecimento, não só as vivências e as experiências, como também a representação do objeto central da enunciação, a visão de mundo e o pertencimento a determinada classe social. Estes e outros aspectos determinam o dizer e o não-dizer, principalmente em se tratando de uma população não habituada a ser ouvida e de pouco falar, como os residentes das instituições asilares.

Nesses discursos que os residentes proferem procurei identificar o que Melucci (1989) define como conflito e solidariedade, componentes presentes nas novas formas de agregação social que embora variem em suas formas são um componente dos sistemas sociais contemporâneos. Para o autor, conflito é uma relação entre atores opostos lutando pelos mesmos recursos e a solidariedade é a capacidade de partilharem uma identidade coletiva. Identidade de grupo que considero difícil construir em um ambiente como a instituição asilar. $\mathrm{Na}$ análise dos discursos procuro também localizar o que declara Foucault (1996) sobre as ideias de disciplina, rigidez e flexibilidade que em qualquer local ou situação representam um sistema de poder. Segundo Pauliukonis (2000), entende-se o conjunto de operações que se encarrega de transformar a língua em discurso como o processo de discursivização, ou seja, é o que faz a passagem do significado (sentido genérico da Língua) para a significação (sentido específico do Discurso). Analisar, portanto, transformando o genérico em específico nas falas.

Ao interpretar os discursos sobre a temporalidade busco entender como se deu o que Rocha e Eckert (2000) definem como a reinvenção de trajetórias sociais pela ruptura com as redes sociais anteriores à entrada na instituição. Em geral quando entram para a instituição os residentes já estavam com uma rede social empobrecida, mas acredito que sempre exista uma 
ruptura nos laços anteriores. Analiso também o que Graeff (2005) mostra em estudo antropológico sobre o caráter social da temporalidade e como os processos naturais como o dia e a noite, a vida e a morte participam do significado cultural de tempo. Em Elias (1993) aparece essa lógica do tempo asilar como sendo ritmado por um número pouco expressivo de cadeias entrelaçadas de ação, o que justificaria a aparência de constante calmaria nesses locais.

Assim, ao analisar a determinação de horários fixos para as atividades de deitar e levantar, o início e o fim das visitas, momentos de tomar medicamentos, entre outras obrigações, busco identificar o que Palmeira (2001) chama de tempo da eternidade, que é a lacuna existente entre essas cadeias entrelaçadas de ações diárias tão pouco expressivas, citadas por Elias (1993).

Segundo Orlandi (1999), ao descrever os dados coletados, o analista também os estará "contaminando" com sua interpretação. Vê-se então a implicação mútua nesta relação, sendo muito difícil manter a neutralidade neste discurso-objeto, mas, conforme afirma a autora, se a fundamentação teórica estiver bem sólida em todos os passos da análise, consegue-se uma melhor qualidade na análise, apesar de não haver um dispositivo de interpretação absoluto, dado a priori. Deste modo, assim como o discurso foi construído, os resultados da análise constroem-se a partir da relação com os dados coletados. 


\section{Capítulo III - Percurso descritivo-analítico}

Neste capítulo descrevo como se deu o andamento da pesquisa nas seis unidades das duas instituições, iniciando com os relatos e impressões da etapa de observação selvagem e a seguir trabalhando com os dados coletados junto aos participantes, primeiramente com as informações dos profissionais e em seguida apresentando e discutindo os dados dos residentes.

1 - Observação Selvagem - impressões

A primeira etapa da pesquisa foi realizada nas quatro unidades da instituição localizada na zona leste de São Paulo, por meio da técnica da Observação Selvagem, cujo relato completo encontra-se no Apêndice A. Acredito ter conseguido em boa parte desta atividade manter a neutralidade em relação ao ambiente conforme sugerido por Altman (1974), pois nos primeiros minutos da minha permanência nos locais havia certa percepção da minha presença, com algumas intenções de interação, mas logo em seguida a rotina seguia seu curso e às vezes eu até terminava minhas observações e ia embora sem que as pessoas percebessem a minha presença.

Nesta importantíssima etapa do meu trabalho pude perceber vários aspectos da vida cotidiana que em momentos posteriores da pesquisa, mesmo aplicando os demais instrumentos ou gravando as entrevistas, não ficaram evidenciados. Sob a ótica da cronobiologia, já nesta primeira etapa emergiram alguns aspectos em relação às regras temporais, a partir das seguintes observações: horário de ir para o quarto a partir das 17:h30min por preferir se recolher a ficar na sala, queixar-se de sono fragmentado provocado pelas interferências, acordar antes do que gostaria pelo barulho e luz a partir das 5 horas da manhã, falta de apetite nas refeições e os cochilos diurnos. Em relação à questão do apetite, percebi, por exemplo vários conflitos com os horários de refeições, tendo em vista que muitos residentes não queriam comer ou mostravam-se indiferentes à chegada deste momento, quando o esperado é que o momento das refeições fosse um fator para estimular a aproximação entre as pessoas. Outro dado importante de observação foi em relação aos cochilos ao longo do dia, o que foi contrastante com as declarações dos mesmos durante a aplicação do questionário sobre hábitos de sono, visto que muitos não percebem esses momentos de cochilo e relatam não cochilarem. O constante estado de mau humor que causava vários atritos entre os residentes foram bem marcantes. Além de tudo, constatei um estado geral de apatia, este sim verificado pelas respostas às questões de satisfação geral com 
a vida e queixas de depressão. O tempo de permanência na cama de boa parte dos idosos em muitos casos é superior a 13 horas, o que, somado aos momentos de cochilo durante o dia, resulta no que eu costumo denominar chamar de presença ausente. Evidentemente a determinação de todas estas dificuldades é multifatorial, o que foi considerado ao fazer a análise das entrevistas gravadas e dos demais instrumentos utilizados.

Não só o cotidiano dos residentes foi observado, mas também a rotina de trabalho da instituição, a série de procedimentos que os profissionais precisam obedecer, o trabalho intenso. O vai-e-vem das visitas é um dos fatores que dificultam o trabalho dos profissionais. A possibilidade de receber visitas a qualquer hora é hoje um dos diferenciais que as instituições oferecem aos familiares, mas o movimento que esta atividade gera, o barulho da campainha e a responsabilidade de abrir e fechar portões colaboram para o aspecto abatido dos profissionais.

2 - Etapa da aplicação dos instrumentos e da constante observação

Durante a minha permanência nos locais, aplicando entrevistas e protocolos ou somente na situação de observadora, busquei me valer dos estudos de Certeau (1998), cujos trabalhos se tornaram um clássico em atividades observacionais do cotidiano. Ele nos ensina que ao observar situações das rotinas cotidianas das instituições sejam elas de que natureza forem devemos atentar para a descoberta sobre como as pessoas procuram oportunidades de subverterem os rituais que as instituições procuram impor sobre elas. Esta subversão é denominada pelo autor de táticas do dia-a-dia que se escondem por trás da máscara da conformidade. Segundo o autor, táticas são criadas para burlar as normas gerando fraturas onde o indivíduo vai para além do imposto. Sim, as relações entre os residentes e a instituição são relações de poder. Onde há poder há resistência e a necessidade de resistir faz uma tática surgir (Foucault, 1985; Certeau, 1998).

Em 05/02/2015 iniciei a pesquisa propriamente dita na primeira instituição com os residentes indicados pelo gerente local, segundo os seguintes critérios de inclusão: estar com a cognição preservada ou com leve comprometimento, não apresentar importantes comprometimentos de linguagem e compreensão e concordar em participar assinando o termo de consentimento. Inicialmente a lista continha 32 nomes que preenchiam os critérios segundo anotação nos prontuários, mas quando retornei para o início do trabalho um dos homens havia falecido e outro saiu da instituição. Foram excluídas as duas participantes da etapa piloto e cinco que, durante a entrevista, constatei apresentarem comprometimento cognitivo. 
$\mathrm{Na}$ primeira instituição foram entrevistados 23 residentes, sendo 17 mulheres e 6 homens com idades entre 75 e 99 anos e com tempo de residência no local entre 2 meses e 4 anos. Cada entrevista teve a duração de aproximadamente 35 minutos. Todas as entrevistas deveriam ser iniciadas após a leitura e assinatura do Termo de Consentimento Livre e Esclarecido, porém, em alguns casos tive que mudar a estratégia ${ }^{3}$.

Em relação aos profissionais da primeira instituição não houve participação na pesquisa, em função da limitação de acesso aos mesmos, o que dificultou uma aproximação maior, conforme detalhei no item Limitações do estudo. De certa forma esta dificuldade foi compensada com as anotações das relações entre profissionais e residentes realizadas durante o estudo observacional.

A pesquisa na segunda instituição não foi precedida da técnica da observação selvagem tendo em vista que minha inserção se deu após ter iniciado atendimento gerontológico particular a uma residente, porém, como pude estar presente durante período mais prolongado nesse local, uma vez por semana, ao longo de seis meses, as anotações da observação participante foram muito importantes para as análises posteriores.

Foram entrevistadas seis residentes, com idades entre 76 e 87 anos, que preencheram os critérios de inclusão utilizados na primeira instituição e que foram indicadas pelo gerente local com base nas suas fichas médicas. Conforme já descrito trata-se de uma instituição que atende residentes com maior complexidade.

As entrevistas gravadas foram transcritas e estão resumidas no Apêndice C, foram analisadas sempre de posse das anotações do diário de campo e dos dados dos protocolos de cada entrevistado. Alguns fatos de natureza geral foram logo evidenciados já nas primeiras observações, tais como: quase nenhum dos residentes entrou para a instituição por escolha própria; muitos foram levados pelos familiares com a promessa de que quando melhorassem voltariam para casa; a maioria recebe visita e apoio de familiares; nenhum mostrou estar feliz por viver naquele ambiente, mesmo sem haver reclamação da forma de tratamento no local; nenhum relatou ter alguém com quem possa ter laços de amizade entre os residentes; a maioria teve respostas que sugerem tendência à depressão.

\footnotetext{
${ }^{3}$ Tive que mudar a abordagem neste particular, pois alguns residentes tiveram receio de assinar o Termo de Consentimento antes de começar a entrevista. Usei como estratégia explicar o objetivo da pesquisa e dizer que eu assinaria o papel como pesquisadora para registrar que havia começado a entrevista e que quando terminasse, a pessoa deveria assinar para mostrar que a entrevista havia sido feita. Somente desta forma consegui aquelas adesões. Em geral as pessoas velhas são muito reticentes em assinar papéis e são orientadas pelos familiares a não fazê-lo.
} 
3 - Análise dos dados dos profissionais e seus sentimentos para com os residentes

Os dados das profissionais que participaram da pesquisa estão apresentados na Tabela 1 e seguidos de algumas análises que foram enriquecidas com os dados observacionais anotados.

Tabela 1 - Dados dos Profissionais

Instituições asilares (n=6). São Paulo, SP, Brasil, 2016

\begin{tabular}{|c|c|c|}
\hline Variáveis & $\mathrm{N}$ & $\%$ \\
\hline \multicolumn{3}{|l|}{ Gênero } \\
\hline Feminino & 06 & 100 \\
\hline \multicolumn{3}{|l|}{ Idade } \\
\hline Média & \multicolumn{2}{|c|}{$25(+/-1,5$ anos $)$} \\
\hline \multicolumn{3}{|l|}{ Função na Instituição } \\
\hline Auxiliar de Enfermagem & 02 & 33 \\
\hline Atendente de Enfermagem & 03 & 50 \\
\hline Enfermeira & 01 & 17 \\
\hline \multicolumn{3}{|l|}{ Tempo na Instituição } \\
\hline Até 1 ano & 04 & 67 \\
\hline Entre 1 e 2 anos & 02 & 33 \\
\hline \multicolumn{3}{|l|}{ Turno de trabalho } \\
\hline Horários regulares & 04 & 67 \\
\hline Horários irregulares & 02 & 33 \\
\hline \multicolumn{3}{|l|}{ Queixas comportamentais } \\
\hline Insônia & 05 & 83 \\
\hline Estresse & 06 & 100 \\
\hline Humor Instável & 03 & 50 \\
\hline Depressão & 02 & 33 \\
\hline
\end{tabular}

Conforme pode ser observado nessa tabela que contém os dados das profissionais que pude coletar na segunda instituição pesquisada, em sua maioria trabalham há pouco tempo na instituição, são bem jovens e apresentam muitas queixas de problemas de saúde, principalmente relativas à insônia e estresse. Mesmo não tendo o dado de rotatividade de profissionais no serviço, foi relativamente simples constatar o fato, visto ter sido recebida por diversas pessoas diferentes ao longo das minhas visitas, o que me dificultou estabelecer vínculos com as mesmas. Neste aspecto, pude observar ouvindo alguns relatos das profissionais, a expressão "pegar experiência" para depois procurar local que remunere melhor. Na primeira instituição também pude constatar esta questão da mudança dos profissionais que me atendiam e foi uma das queixas do administrador local ter que lidar com a alta rotatividade dos trabalhadores. Este é um fator que dificulta a criação e manutenção de laços entre os residentes e o pessoal que lá trabalha, reforçando o caráter da relação como prestação de serviços e não de pertencimento. Percebi que na segunda instituição visitada, onde o valor das mensalidades cobradas dos residentes é inferior ao da primeira, a rotatividade de profissionais é bem maior, levando a crer que se trata de uma primeira 
oportunidade de emprego para pessoas em qualificação ou recém qualificadas na área, já que a exigência nesse quesito experiência é bem menor. Outro fato importante é que, a despeito da juventude, as queixas de problemas de saúde são várias e o relato de insônia e de estresse está presente em quase todas as respostas. De fato, pude observar que as pessoas trabalham num ritmo bastante acelerado, apresentam um semblante cansado e sério. Quando elas não estão cuidando dos residentes, estão fazendo anotações nos seus prontuários.

Todo este quadro que estou descrevendo serve como pano de fundo para analisar como estas profissionais enxergam os residentes, ou pacientes, como são chamados. Pude presenciar a entrada de novos residentes nas duas instituições e todas foram cenas tristes, conforme descrevo mais adiante ainda neste capítulo. Em todas as situações da entrada de novos pacientes, os familiares se retiraram sem ser vistos, enquanto as auxiliares tentavam distrair a pessoa.

Segundo Neri (2002), em geral os motivos para uma pessoa ser levada para uma instituição asilar incluem apresentar declínio cognitivo, imobilidade, idade superior a 70 anos, baixa renda, ser do sexo feminino, ser viúva(o), não ter filhos e morar só. Ou seja, todos esses fatores representam um quadro de fragilidade e dependência com os quais os profissionais terão que lidar em seu trabalho diário. Se esta situação de fragilidade e dependência estiver presente e ainda o idoso for "internado" contra a sua vontade numa posição submissa, considero termos aí um quadro que pode suscitar diversos sentimentos nos profissionais em relação ao novo residente, o que vai impactar a sua forma de conduta em relação ao mesmo. E nesta conduta podem estar presentes dois modos de olhar para aquela pessoa, representados por dois sentimentos: indiferença ou piedade. A indiferença pode se manifestar quando o profissional percebe que, se o próprio familiar da pessoa o internou de maneira forçada, isto pode ser relacionado com uma atitude de desvalorização, ou seja despersonalização do indivíduo e o profissional pode não se sentir compromissado em respeitar as vontades do residente, limitando-se apenas a fazer o seu trabalho. Já a piedade pode se manifestar quando o profissional olha para o idoso como uma pessoa digna de pena, o que favorece oferecer-lhe um tratamento protecionista. Concordo com a autora que escreve sobre caridade e compaixão, (Caponi, 2000), quando ela cita que a caridade e a piedade colocam o paciente na situação de debilidade mais absoluta e de impotência. Uma pessoa que tem compaixão pela outra tem o impulso de socorrê-la e fazer por ela, sem avaliar se o seu socorro é ou não desejado por aquele que é alvo desta compaixão. Em sua análise, Caponi (2000) cita Nietzsche que, em seus escritos de "Genealogia de la moral", se refere a estas atitudes compassivas como uma relação de poder, pois os que fornecem auxílio e assistência reforçam 
a submissão e a docilização sobre aqueles que os recebem. Nietzcshe explica que o sentimento de piedade leva a fazer o bem para o outro não como semelhante, mas como superior e ele descreve essa relação de poder dessa maneira: "nossos benfeitores diminuem nosso valor e nossa vontade, ainda mais que nossos próprios inimigos". A princípio este pensamento expresso por Nietzcshe pode parecer muito mordaz, mas ele é bem realista. Para complementar esta ideia, Caponi (2000) define que para aproximar a relação entre as duas partes seria preciso colocar o respeito acima da compaixão e a solidariedade acima da piedade, com o que concordo. Enfatizando: ao invés de compaixão e piedade, respeito e solidariedade!

Por compreender que a realidade hoje vivida nas instituições asilares está ligada a um contexto histórico e social que construiu suas bases e que, mesmo que mudanças tenham sido e estejam sendo feitas, muitos traços se perpetuam, mesmo que no subconsciente coletivo. Para melhorar meu entendimento sobre a origem dos modelos de instituições para idosos, busquei autores que estudaram a história do nascimento dos asilos no Brasil e encontrei em Groisman (1999) que as institucionalizações inicialmente eram destinadas a indigentes e pobres, o que atribuía a elas o caráter de piedade caridosa, conforme já citado em Caponi (2000). Num segundo momento, a esta prática assistencial passa-se a acrescentar o discurso médico higienista e também a serem criados os locais específicos para velhos e isto foi um marco para a velhice, no final do século XIX. Ao se colocarem os velhos em ambientes separados de outros grupos sociais em vulnerabilidade, abriu-se espaço para que a velhice passasse a ser considerada de maneira homogênea, o que na visão de Groisman (1999), produziu a ideia de "velhice desamparada". Segundo Barbieri (2008), naquele momento já se desenhava a perspectiva medicalizante e as transformava em instituições médicas, portanto, locais de cuidados constantes. Concordo com as ideias apresentadas pela autora a respeito da chegada da medicalização da velhice às instituições, que veio com o objetivo de melhorá-las, mas trouxe consigo a necessidade de uma rotina estruturada em protocolos que determinam a vida cotidiana. Com base em protocolo medicalizante a instituição asilar não atende ao modelo de moradia, mas sim ao modelo de cuidados médicos. Estes aspectos da determinação das rotinas, apontados por Barbieri (2008), foram por mim constatados, conforme menciono em diversos relatos das entrevistas e das situações cotidianas por mim observadas, tendo em vista ser objetivo na minha pesquisa analisar as temporalidades dos sujeitos (tempos biológicos) em função da temporalidade das instituições (tempos sociais).

Valendo-me das anotações do diário de campo pude observar que o fato de as pessoas serem institucionalizadas em sua grande maioria sem o seu conhecimento ou aquiescência, 
aliado ao trabalho estressante que representa para estes profissionais, há uma grande probabilidade de ocorrer o que Foucault (2004) chama de docilização dos corpos dos pacientes, ou seja, a sujeição mediante a necessidade. E da parte dos residentes percebe-se certa resignação com este tratamento. Relatos neste sentido serão comentados no capítulo do percurso analítico. A seguir passo a detalhar o perfil dos residentes participantes da pesquisa e os dados qualitativos coletados, relativos aos diversos domínios analisados.

4 - Análise de dados dos residentes

Os dados obtidos na pesquisa junto aos residentes estão mostrados e discutidos inicialmente pelo perfil sociodemográfico do grupo estudado, seguido dos dados de satisfação com a vida em relação à saúde e de percepção de velhice. Os dados que representam os hábitos de sono, depressão e determinação do cronotipo estão discutidos em separado, mas foram também analisados com base em ferramentas estatísticas. A opção por incluir as estatísticas foi analisar as tendências nas relações entre as variáveis selecionadas.

\subsection{Dados do Questionário com variáveis Sociodemográficas e Psicossociais}

Na Tabela 2 estão descritas as variáveis que permitem observar o perfil sociodemográfico dos residentes nas instituições pesquisadas, seguidas das análises.

Tabela 2 - Perfil sociodemográfico dos residentes (N=29). São Paulo, SP, Brasil, 2016.

\begin{tabular}{|c|c|c|}
\hline Variáveis & $\mathrm{N}$ & $\%$ \\
\hline \multicolumn{3}{|l|}{ Gênero } \\
\hline Feminino & 21 & $72 \%$ \\
\hline Masculino & 8 & $28 \%$ \\
\hline \multicolumn{3}{|l|}{ Estado Civil } \\
\hline Viúvo(a) & 19 & $66 \%$ \\
\hline Solteiro(a) & 4 & $14 \%$ \\
\hline Separado(a) & 1 & $3 \%$ \\
\hline Sem resposta & 1 & $3 \%$ \\
\hline Divorciado(a) & 1 & $3 \%$ \\
\hline Casado(a) & 3 & $10 \%$ \\
\hline \multicolumn{3}{|l|}{ Idade } \\
\hline $75 \mid-80$ & 3 & $10 \%$ \\
\hline $80 \mid-90$ & 11 & $48 \%$ \\
\hline $90 \mid-99$ & 10 & $42 \%$ \\
\hline \multicolumn{3}{|c|}{ De acordo com sua escolaridade você estudou, formalmente, durante: } \\
\hline $0 \mid-5$ & 24 & $83 \%$ \\
\hline $5 \mid-10$ & 2 & $7 \%$ \\
\hline $10 \mid-15$ & 1 & $3 \%$ \\
\hline $15 \mid-20$ & 1 & $3 \%$ \\
\hline Sem resposta & 2 & $7 \%$ \\
\hline \multicolumn{3}{|l|}{ Com quem morava antes } \\
\hline Com os Filhos & 3 & $10 \%$ \\
\hline Outra pessoa morava com o(a) senhor(a) & 5 & $17 \%$ \\
\hline Somente com o Cônjuge & 4 & $14 \%$ \\
\hline Sozinho (a) & 15 & $52 \%$ \\
\hline Sem resposta & 2 & $7 \%$ \\
\hline
\end{tabular}


Observando estes dados constantes da Tabela 2 podemos confirmar o que aparece nas estatísticas já citadas neste trabalho, ou seja, a maior presença feminina, baixa renda, baixa escolaridade, o residir sozinho antes na institucionalização e a idade acima dos 80 anos.

As pessoas do gênero feminino representam mais de $70 \%$ dos residentes, o que confirma o fenômeno denominado feminização da velhice. As mulheres vivem mais do que os homens, o que pode ser atribuído aos maiores cuidados de saúde durante a vida e também à menor exposição a riscos externos do que os homens. Porém, segundo Neri (2001), esse tempo de vida maior para as mulheres não significa viver melhor, pois as expõe a riscos crescentes em termos de saúde, funcionalidade, proteção e integração social. Segundo a autora esta longevidade se deu em condições de baixa escolaridade, baixa renda e diferenças de oportunidades entre homens e mulheres, as quais prejudicaram as mulheres, pois gerou dependência econômica que se exacerba ao enfrentar a viuvez. A quantidade de mulheres viúvas também está presente na população estudada, conforme apresentado na Tabela 1. Segundo Veras (1994), estas mulheres que vivem sós e têm idades mais avançadas tendem a ser mais queixosas e a ter baixa autoestima. Dentre as pessoas incluídas na pesquisa apenas três (mulheres) eram casadas e, apesar de não viverem sozinhas, foram morar na instituição. Geralmente o que ocorre é que quando elas adoecem seus maridos não se sentem capazes de cuidar delas, já que esse papel de cuidadora foi sempre exercido pelas mulheres.

Estes dados mais objetivos apresentados até o momento são complementados por questões mais subjetivas que fazem parte do questionário sociodemográfico que inclui os blocos de satisfação com a vida em referência aos domínios: Saúde, Capacidade física, Capacidade mental e Envolvimento social, tanto da própria pessoa quanto comparado com outras pessoas da mesma idade. Nos diversos domínios poderiam atribuídas às questões notas entre 1 e 5, sendo 1 o grau de maior insatisfação e 5 o de maior satisfação. Os participantes, em sua maioria, atribuíram as notas mais baixas (1 e 2), as quais sinalizam insatisfação. Essa insatisfação foi relativa aos domínios: saúde, capacidade física e integração social; a exceção foi a avaliação da capacidade mental. Esse fato chamou-me a atenção, pois 23 responderam que estavam satisfeitos, tanto com a própria capacidade mental, quanto com sua capacidade mental comparada com os demais residentes. Neste particular considero que os respondentes, que eram pessoas com capacidade cognitiva mais preservada, reconhecem esta situação ao olharem para os residentes que diagnosticados com demência de Alzheimer, por isto consideram positivo e valorizam o fato de que, apesar de outras dificuldades, conseguem ter domínio sobre sua consciência. 


\subsection{Satisfação com a vida relacionada a domínios}

Na Tabela 03 são apresentados os dados dessa percepção de sua situação comparada com outras pessoas da mesma idade.

Tabela 3 - Satisfação com a vida relacionada a domínios.

\begin{tabular}{|c|c|c|c|c|c|c|c|c|c|c|c|c|c|}
\hline \multirow[t]{2}{*}{ Domínios } & \multicolumn{2}{|c|}{$\begin{array}{c}\text { Muito } \\
\text { pouco } \\
\text { satisfeito }\end{array}$} & \multicolumn{2}{|c|}{$\begin{array}{c}\text { Pouco } \\
\text { satisfeito }\end{array}$} & \multicolumn{2}{|c|}{$\begin{array}{l}\text { Mais ou } \\
\text { menos } \\
\text { satisfeito }\end{array}$} & \multicolumn{2}{|c|}{$\begin{array}{c}\text { Muito } \\
\text { satisfeito }\end{array}$} & \multicolumn{2}{|c|}{$\begin{array}{c}\text { Muitíssimo } \\
\text { satisfeito }\end{array}$} & \multicolumn{2}{|c|}{$\begin{array}{l}\text { Não há } \\
\text { respostas }\end{array}$} & \multirow{2}{*}{$\begin{array}{c}\text { Total } \\
\%\end{array}$} \\
\hline & $\mathrm{n}$ & $\%$ & $\mathrm{~N}$ & $\%$ & $\mathrm{~N}$ & $\%$ & $\mathrm{~N}$ & $\%$ & $\mathrm{n}$ & $\%$ & $\mathrm{n}$ & $\%$ & \\
\hline $\begin{array}{l}\text { Minha saúde hoje comparada } \\
\text { com a de outras pessoas da } \\
\text { minha idade }\end{array}$ & 3 & $10 \%$ & 2 & $7 \%$ & 5 & $17 \%$ & 13 & $45 \%$ & 3 & $10 \%$ & 3 & $10 \%$ & $100 \%$ \\
\hline Minha capacidade física & 2 & $7 \%$ & 7 & $24 \%$ & 8 & $28 \%$ & 7 & $24 \%$ & 2 & $7 \%$ & 3 & $10 \%$ & $100 \%$ \\
\hline Minha capacidade mental & 1 & $3 \%$ & 2 & $7 \%$ & 3 & $10 \%$ & 16 & $55 \%$ & 4 & $14 \%$ & 3 & $10 \%$ & $100 \%$ \\
\hline $\begin{array}{l}\text { Meu envolvimento social } \\
\text { hoje }\end{array}$ & 6 & $21 \%$ & 8 & $28 \%$ & 2 & $7 \%$ & 8 & $28 \%$ & 2 & $7 \%$ & 3 & $10 \%$ & $100 \%$ \\
\hline
\end{tabular}

Continuando ainda com as questões do protocolo sociodemográfico no que diz repeito à variável satisfação geral com a vida, utilizamos a figura de uma escada para a pessoa informar em que degrau ela considera que esteja sua vida no momento. Na escada, o degrau 1 representa a maior insatisfação em relação à vida no momento e o degrau de número 10 representa a melhor satisfação com a vida atual. Por ser bem visual, as pessoas tiveram facilidade para identificar a própria situação nos degraus. A quantidade de escolhas encontrase ao lado do número do degrau e, como pode ser observado, a maior quantidade de respostas situou-se no degrau de valor 5 (31\%); a maioria de escolhas se deu nos degraus abaixo de 5, somando 15 respostas (51,7\%). Interessante notar que a escolha pela melhor vida, degrau 10, foi relativamente alta, com 6 escolhas $(20,6 \%)$. A Figura 1 mostra as escolhas dos residentes na escada da vida. 
Qual é o ponto dessa escada que melhor reflete a sua satisfação com a sua própria vida?

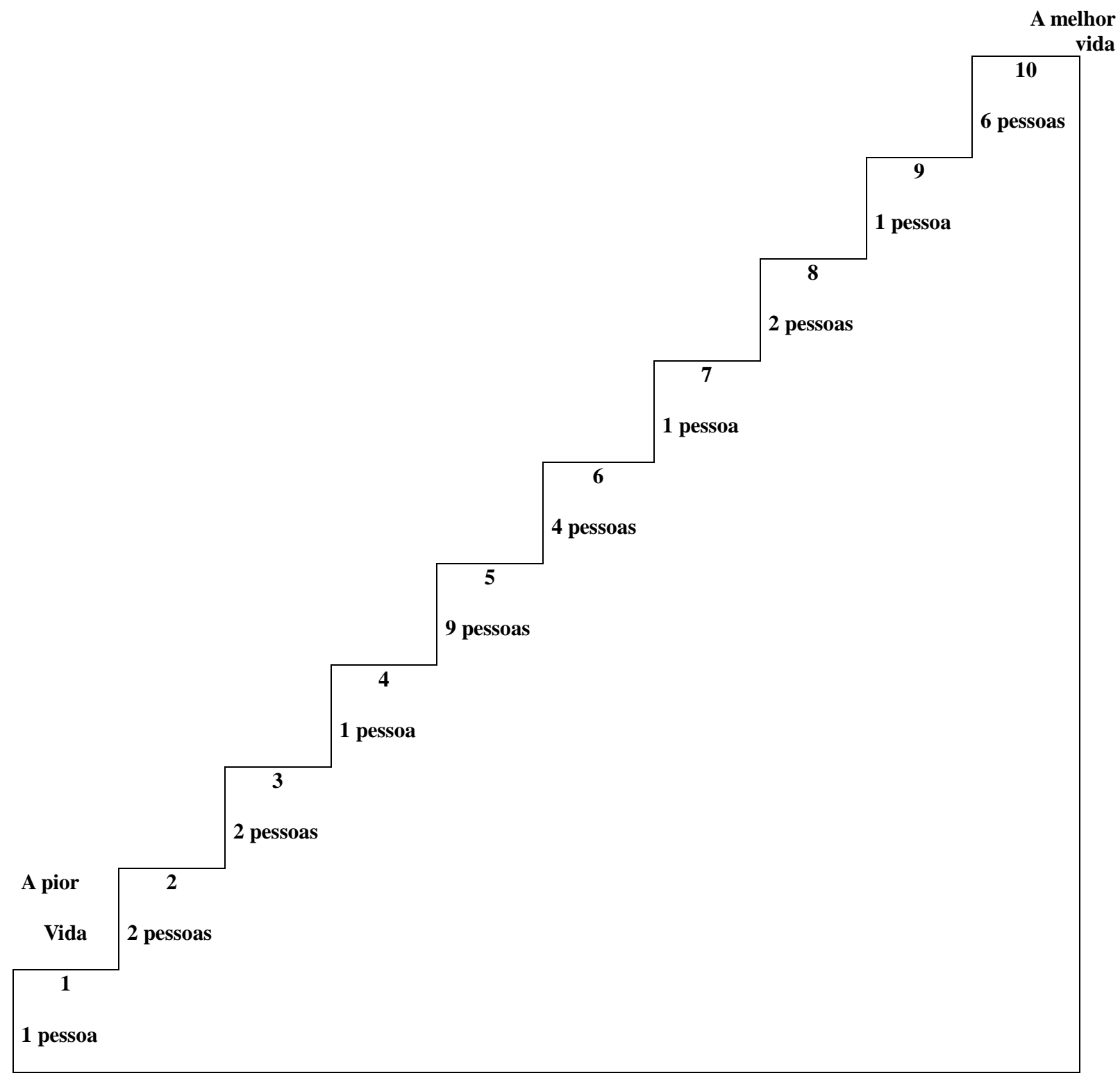

Figura 1: satisfação geral com a vida. 


\subsection{Depressão}

Os dados obtidos a partir da aplicação da escala geriátrica de depressão reduzida (GDS-15), foram analisados segundo sugerem Almeida e Almeida (1999). O critério sugerido por esses autores é: pontuação entre os valores 1 e 4 - ausência de sinais de depressão; pontuação 5 e 6 - estado de distimia, ou seja, a falta de prazer pela vida e sentimento de negatividade; pontuação entre 7 e 15 - presença de sintomas de depressão maior.

Conforme podemos observar na Tabela 4, há tendência para a depressão maior e para a distimia entre os residentes. As mulheres apresentam mais sintomas depressivos, tanto distimia quanto depressão maior. Uma possível explicação para este quadro é o sentimento de solidão pela experiência da viuvez.

Tabela 4. Pontuação relacionada a queixas de depressão na amostra total (n=29) e estratificada por gênero. São Paulo, SP, Brasil, 2016.

\begin{tabular}{lccccccc}
\hline & \multicolumn{2}{c}{ Amostra Total } & \multicolumn{3}{c}{ Feminino } & \multicolumn{2}{c}{ Gênero } \\
\cline { 5 - 8 } Classificação GDS-15* & $\mathrm{N}$ & $\%$ & $\mathrm{n}$ & $\%$ & $\mathrm{~N}$ & $\%$ \\
\hline Sem sinais (1-4) & 7 & 24 & & 4 & 17 & 3 & 50 \\
Distimia (5-6) & 8 & 28 & & 7 & 30 & 1 & 17 \\
Depressão maior (7-15) & 14 & 48 & & 12 & 52 & 2 & 33 \\
\hline * Geriatric Depression Scale. & & & & & & &
\end{tabular}

\subsection{Percepção da velhice}

No questionário existem três perguntas sobre percepção da velhice; a primeira é se eles se sentem idosos, a segunda é em que idade começa a velhice e a terceira é uma pergunta aberta para eles definirem o que seria uma boa velhice. Todos responderam que não se sentem idosos. A maioria respondeu que não existe uma idade certa para se considerar velho e os que definiram um número para o início da velhice, foi uma idade posterior à deles. Estas respostas e citações das pessoas confirmam o que Elias (1993) escreve sobre ser a velhice um segredo desagradável de se conhecer, ou seja, não estando na condição, não preciso falar sobre ela. Segundo Neri (2007) na velhice, não nos reconhecemos velhos e, à medida que envelhecemos, tendemos a fixar em idades cada vez mais avançadas aquela que marca a entrada na última fase do curso de vida. Também me chamou a atenção que as frases para definir o que seria uma boa velhice, em nenhum caso se encaixa em viver em uma casa de repouso, conforme está exemplificado a seguir nos comentários agrupados por assunto (Tabela 5). 
Tabela 5 - Emissões relacionadas à velhice.

\begin{tabular}{|c|c|}
\hline $\begin{array}{l}\text { Percepção da velhice } \\
\text { Assunto discursivo }\end{array}$ & Comentários \\
\hline Boa velhice & $\begin{array}{l}. \text { Isso eu não vou ter } \\
. \text { Seria voltar para casa } \\
. \text { Não existe } \\
. \text { Eu não lembro o que é... } \\
\text {.Ah, Eva me leva pro paraíso agora! } \\
\text {.Seria enxergar... para ver quem está cuidando de } \\
\text { mim } \\
. \text { Seria gostar de onde se vive } \\
\text {.Boa velhice, como? } \\
\text {.Ter mais família }\end{array}$ \\
\hline Conformidade & $\begin{array}{l}\text { Ir levando numa boa porque não tem outro jeito } \\
\text {.Está bom, mas queria ter alguém por perto } \\
\text {. Aprendi que a vida é mais simples do que a gente } \\
\text { pensa } \\
\text {.Aceitar as condições, não ficar chorando pelos } \\
\text { cantos }\end{array}$ \\
\hline Revolta & $\begin{array}{l}\text {.Viver onde seja cuidado e não mandado } \\
\text {.Ter saúde física e mental pra poder sair daqui... } \\
\text { não adianta eu ter cabeça boa se minha perna não } \\
\text { ajuda } \\
\text {.Os filhos cuidarem bem da gente } \\
\text {.Não parar de trabalhar, nem estudar } \\
\text {.Fora da casa da gente não é a mesma coisa } \\
\text {.É não conseguir fazer as coisas por si só... as } \\
\text { pessoas são prepotentes e acham que a gente não } \\
\text { tem vontade própria } \\
\text {.Minha filha me pôs aqui para não ter trabalho. }\end{array}$ \\
\hline Sonho & $\begin{array}{l}. E ́ \text { ter paz, sossego, receber os filhos } \\
. \text { Morar na própria casa } \\
\text {.Andar no quintal de casa, ver as netas... } \\
\text {.Ter saúde e estar bem de cabeça } \\
\text {.Ter um marido bom para sempre } \\
\text {.Viver em paz com todo mundo e trabalhar } \\
\text { honestamente } \\
\text {.O essencial para todos nós é a saúde aí a gente } \\
\text { consegue tudo }\end{array}$ \\
\hline
\end{tabular}

Percebi que os idosos, de certa forma, estabelecem um distanciamento com seu próprio corpo referindo-se a ele particionado e em terceira pessoa, como em uma citação nesse quadro anterior quando a residente diz que a perna não a ajuda a andar. Em outros momentos observei outras que disseram, por exemplo, "eи quero andar, mas meu corpo não quer"; "minha perna não quer sair do lugar"; "se meu braço me obedecesse eu faria palavras cruzadas", "ah se meu olho me obedecesse eu ia escrever minha história”. 


\subsection{Determinação de Matutinidade-Vespertinidade}

Outro instrumento de pesquisa aplicado foi um questionário para apontar as preferências das pessoas por atividades em determinados horários do dia, denominado característica de matutinidade/vespertinidade ou cronotipo. Considerando este questionário, foi possível notar a tendência dos indíviduos idosos à matutinidade, o que é confirmado pelos estudos que apontam para o caráter ontogenético da preferência para atividades, segundo os quais, quanto mais velha for a pessoa, mais ela tende a ser matutina, mesmo que na maior parte de sua vida tenha se classificado como indivíduo mais vespertino (Andrade, MennaBarreto e Louzada,1999). Neste particular acredito que as rotinas de atividades estabelecidas pelas duas instituições estão condizentes com o caráter de matutinidade dos residentes. $\mathrm{Na}$ medida em que detectamos diferenças entre os participantes (cronotipos, queixas, etc.), é razoável supor que as regras temporais da instituição exerçam impactos distintos nos indivíduos, mais contrastantes em alguns, menos contrastante em outros.

\subsection{Hábitos de Sono}

O instrumento diário de sono comumente vem sendo utilizado em pesquisas no Grupo Multidisciplinar de Desenvolvimento e Ritmos Biológicos (GMDRB) e tem como recomendação ser aplicado pelo menos em nove dias consecutivos, o que engloba um fim de semana, pois se pressupõe que nos finais de semana as pessoas tenham horários diferenciados de sono. Isto permite que se analise privação de sono ao longo de um intervalo de tempo. E, na maioria dos estudos em que é utilizado, o diário de sono é preenchido pelo próprio participante. Nesta pesquisa eu tive que preencher o protocolo, a partir das informações do sono deles da noite anterior, pois eles não teriam condição de fazê-lo. A cada dia em que eu ia entrevistar os residentes, aproveitava e preenchia o diário de sono com outros que já haviam participado. Porém, ao preencher o diário de 6 pessoas por 3 dias consecutivos, ou seja, 18 ocorrências, percebi que todos os itens eram respondidos igualmente em todas os dias (horário de deitar, número de vezes que acordou, horário de acordar, como foi acordado, se cochilou durante o dia). Isto me fez interromper a aplicação na forma em que iniciei e aplicar uma vez para cada participante para obter o panorama de seus hábitos de sono. As comparações entre os hábitos de sono, cronotipo e sintomas de depressão por gênero e idade foram feitas por análises estatísticas e se encontram descritas a seguir.

4.7 Apresentação estatística das variáveis depressão, sono e cronotipo

Para descrever o perfil da amostra, foram feitas tabelas de frequência e estatísticas descritivas, como medidas de posição e dispersão. Pelos testes de Kolmogorov-Smirnov e 
Shapiro-Wilk (Figura 2) foram analisadas as distribuições das variáveis contínuas. A idade e a pontuação de cronotipo e GDS-15 seguiram a distribuição normal, entretanto a variável relacionada a horários (sono) não apresentou distribuição normal. Assim, para comparação das variáveis categóricas entre os grupos foram utilizados o testes paramétricos (teste t para comparar dois grupos e Anovas para comparar mais de dois grupos) e não-paramétricos (teste U de Mann-Whitney para comparar dois grupos e Kruskal-Wallis para comparar três grupos). A relação entre as variáveis também foi analisada, por meio de correlações de Spearman.

Os dados foram digitados no Excel da Microsoft e para as análises estatísticas foram utilizados os programas computacionais SPSS v.17.0 e Statistica v. 7.0. O nível de significância adotado para os testes estatísticos foi de $5 \%$, ou seja, $p$-valor $<0.05$.

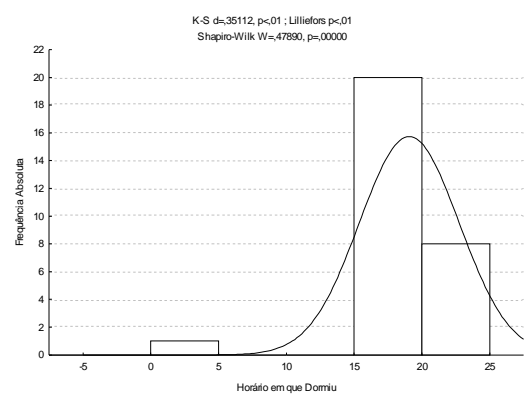

Distribuição do horário em que os entrevistados dormiram no dia anterior.

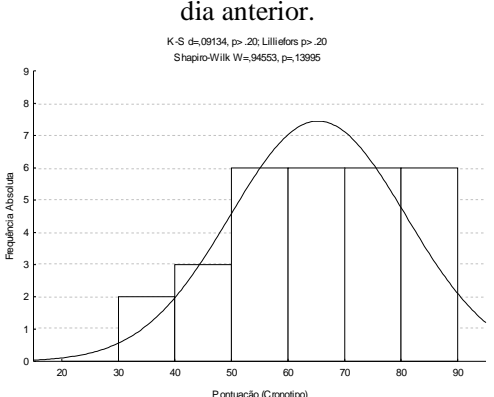

Distribuição da Pontuação na Avaliação do Cronotipo.

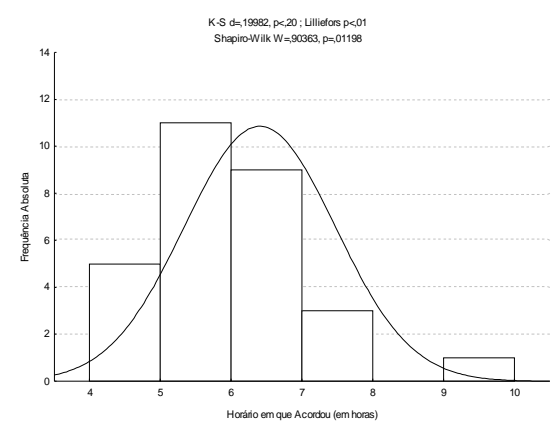

Distribuição do horário em que os entrevistados acordaram.

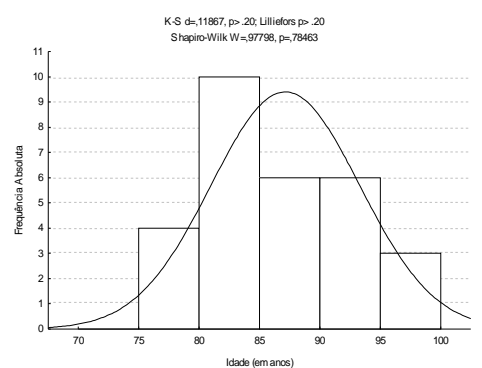

Distribuição da idade dos entrevistados.

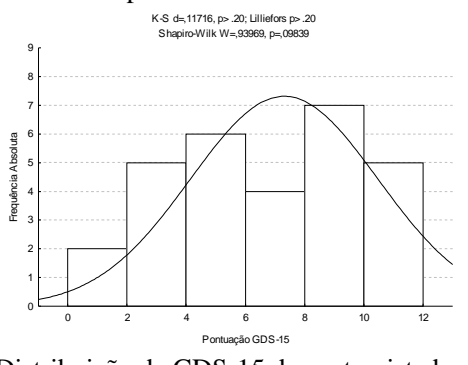

Figura 2. Resultados dos testes de Kolmogorov-Smirnov e Shapiro-Wilk.

\subsubsection{Comparação por gênero}

O presente estudo contou com a participação de 21 mulheres e 8 homens idosos. Os dois grupos se diferenciaram estatisticamente quanto à idade, sendo que o grupo de homens (Média: 91.13 E.P.: \pm 2.13 ) se apresentou com a média de idade superior ao das mulheres (Média: 85.62 E.P.: \pm 1.22 ). 


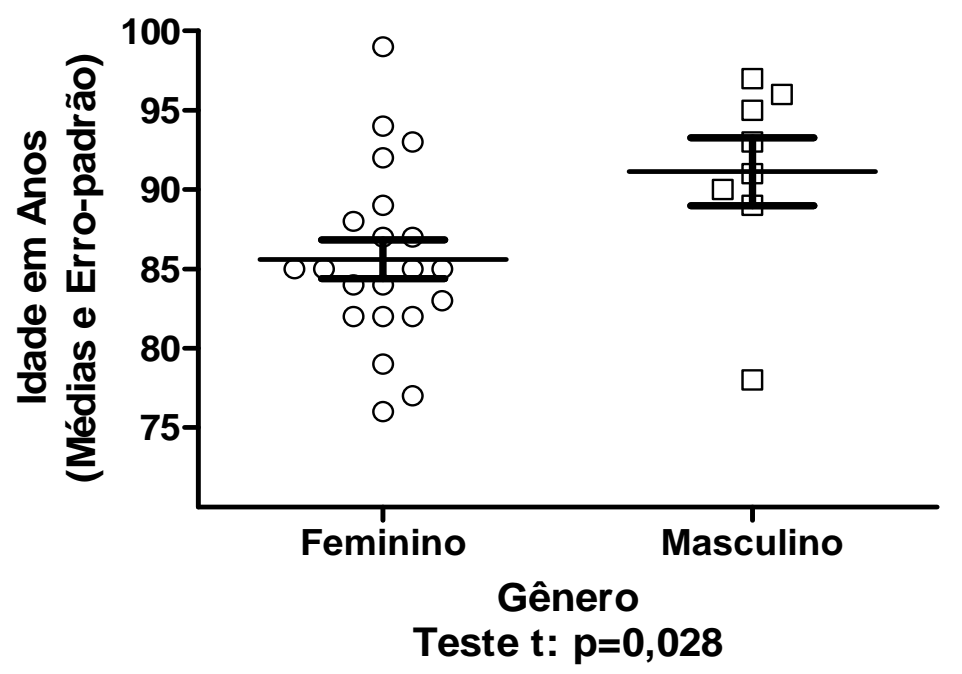

Figura 3. Idade entre os gêneros.

Quanto ao cronotipo, a pontuação para as mulheres foi 68,24 (Erro-Padrão: \pm 3.11), para os homens foi 57,63 (Erro-Padrão: \pm 6.04 ). A comparação do Cronotipo em relação foi analisada pelo teste $\mathrm{t}$ de amostra independente, o resultado não se mostrou significativo, apesar da média do cronotipo ter sido maior para as mulheres. Isso pode ser explicado pelo reduzido número da amostra.

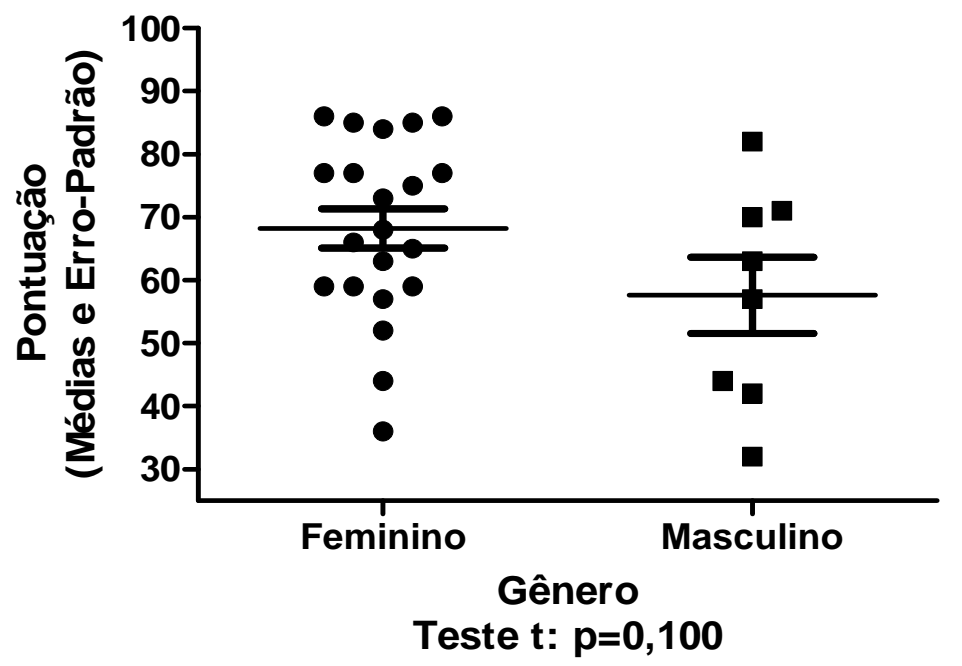

Figura 4. Distribuição da pontuação (cronotipo) entre homens e mulheres.

4.7.2 Comparação de hábitos de sono

Também foram realizadas comparações entre os horários em que dormiram e acordaram os participantes de ambos os gêneros. Em média, os homens dormiram mais cedo que as mulheres e acordaram mais cedo. Entretanto, estatisticamente, não foi identificada tal diferença entre homens e mulheres na amostra estudada, apenas se verificou uma tendência (Figura 5). 

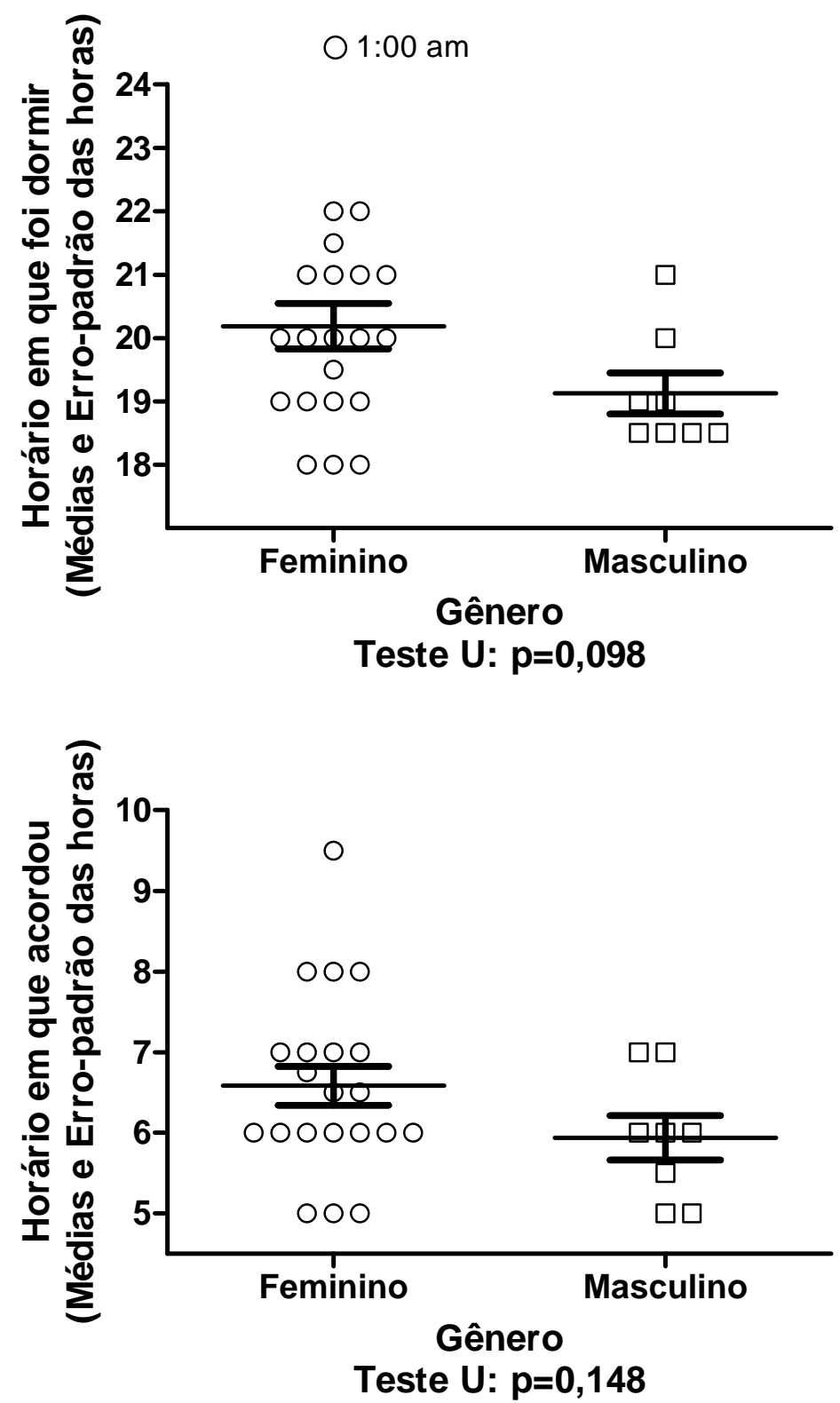

Figura 5. Horários em que dormiram e acordaram os idosos entrevistados.

Na Figura 6, os idosos foram estratificados em dois grupos: o primeiro não acordou a noite, o segundo acordou e voltou a dormir. Nota-se que os participantes do segundo grupo (Média: 91.25, E.P. \pm 2.17) são estatisticamente mais velhos em relação aos idosos do primeiro grupo (Média 85.57, E.P. \pm 1.20 ). 


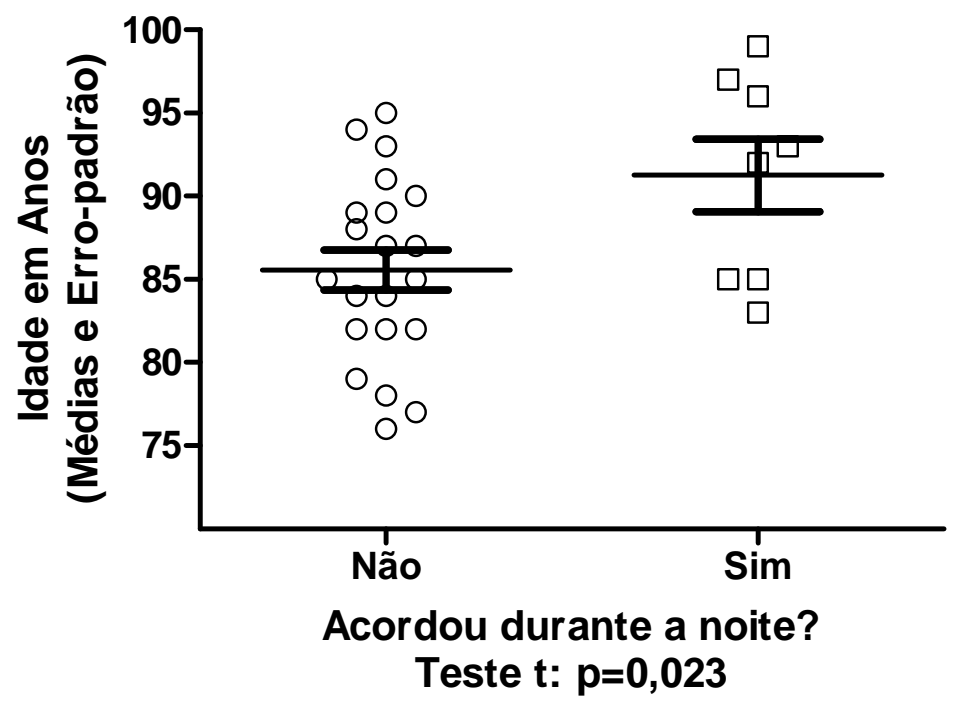

Figura 6. Idade entre os participantes de grupos diferentes (ter acordado e dormido novamente).

Quanto ao cronotipo, a pontuação para os que não acordaram a noite foi 64,00 (ErroPadrão: \pm 3.59), para os que acordaram foi de 57,63 (Erro-Padrão: \pm 6.04 ). A comparação do Cronotipo em relação foi analisada pelo teste $t$ de amostra independente, o resultado não se mostrou significativo, apesar da média do cronotipo ter sido maior para os que não acordaram durante o sono.

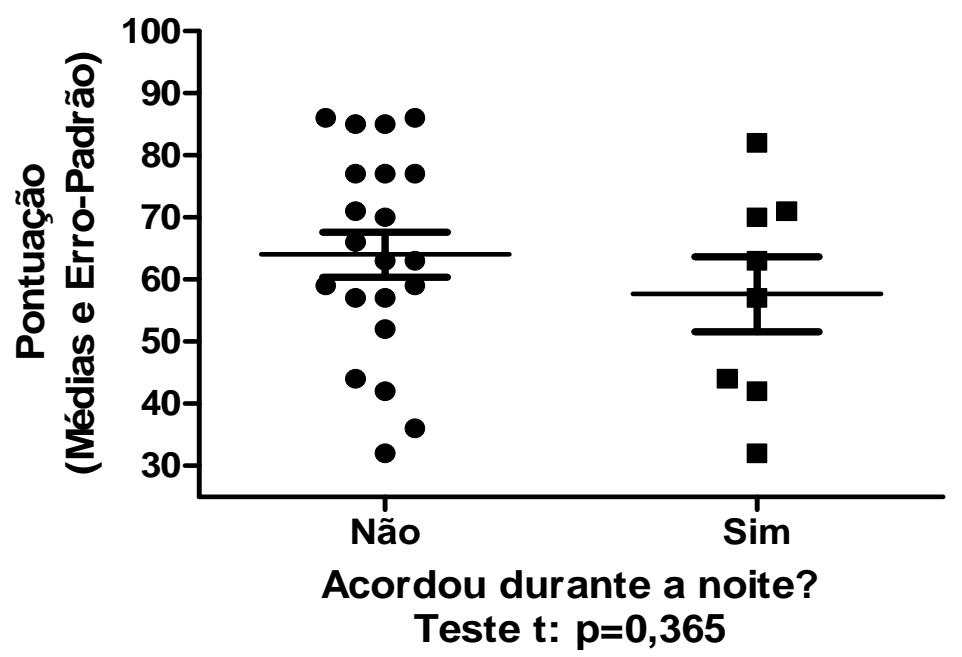

Figura 7. Pontuação entre os participantes de diferentes grupos no questionário do cronotipo (matutinidade/vespertinidade).

Também foram realizadas comparações entre os horários em que dormiram e acordaram os participantes que acordaram ou não durante a noite de sono. Estatisticamente, não foi identificada diferença entre os participantes da amostra estudada (Figura 8). 

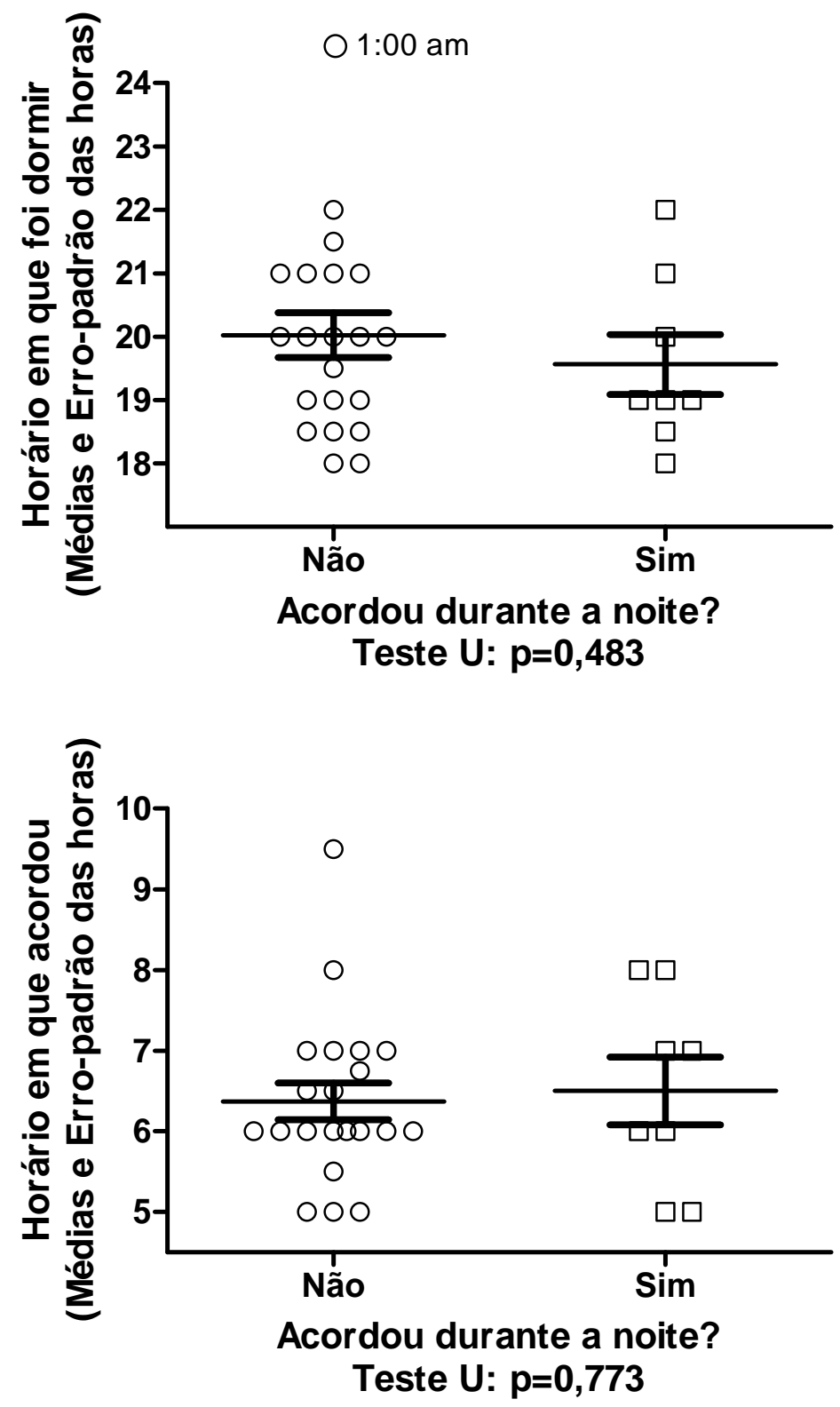

Figura 8. Distribuição dos horários nos quais dormiram e acordaram.

Na Figura 9, os idosos foram estratificados de acordo com o modo que acordaram: por outras pessoas ou espontaneamente. Estatisticamente, não se notou diferença entre os grupos, apenas uma leve tendência, aqueles que acordaram espontaneamente são mais idosos.

Conforme eu já havia notado nas observações, os residentes vão para a cama relativamente cedo e também acordam cedo, mas é interessante que a maioria relata ter sido acordado, o que inclui ter sido acordado pelo barulho, pela iluminação e a presença do pessoal de enfermagem no início da rotina diária. Os que informam acordarem espontaneamente em geral são os que dormem em aposentos com um número menor de acompanhantes, ou em quartos individuais, mesmo assim são horários bem matutinos. 


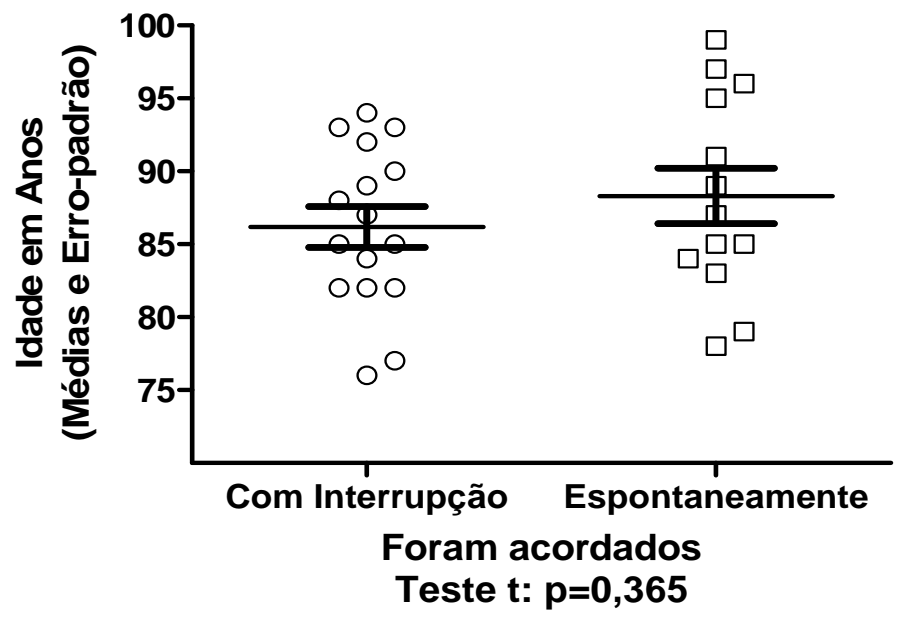

Figura 9. Idade entre os participantes de grupos diferentes (foram acordados ou despertaram espontaneamente).

Quanto ao cronotipo, Figura 10, a pontuação foi analisada pelo teste t de amostra independente, o resultado não se mostrou significativo, os grupos se apresentaram semelhantes.

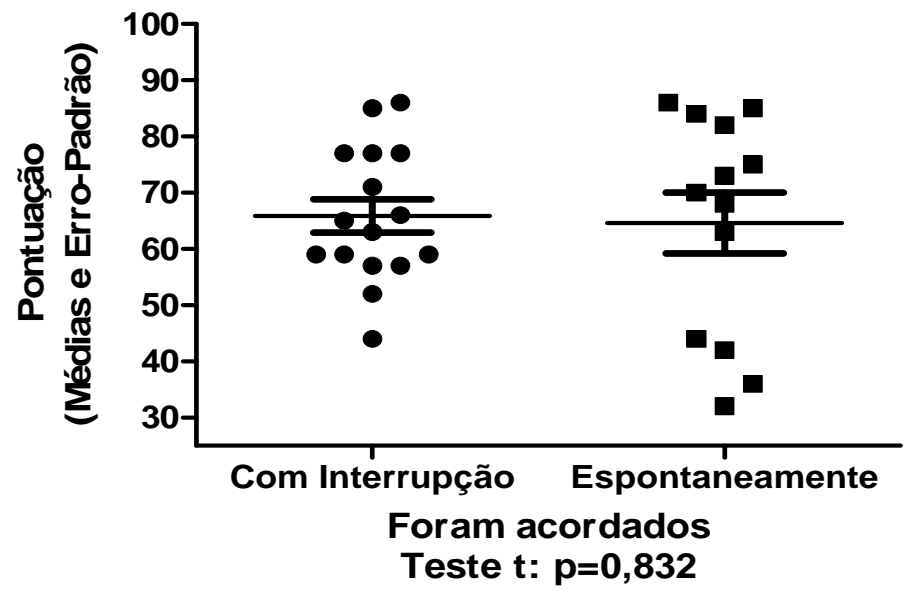

Figura 10. Pontuação entre os participantes de diferentes grupos (foram acordados ou despertaram espontaneamente).

Também foram realizadas comparações entre os que acordaram com interrupção e espontaneamente. Estatisticamente, não foi identificada diferença entre os participantes da amostra estudada (Figura 11). 

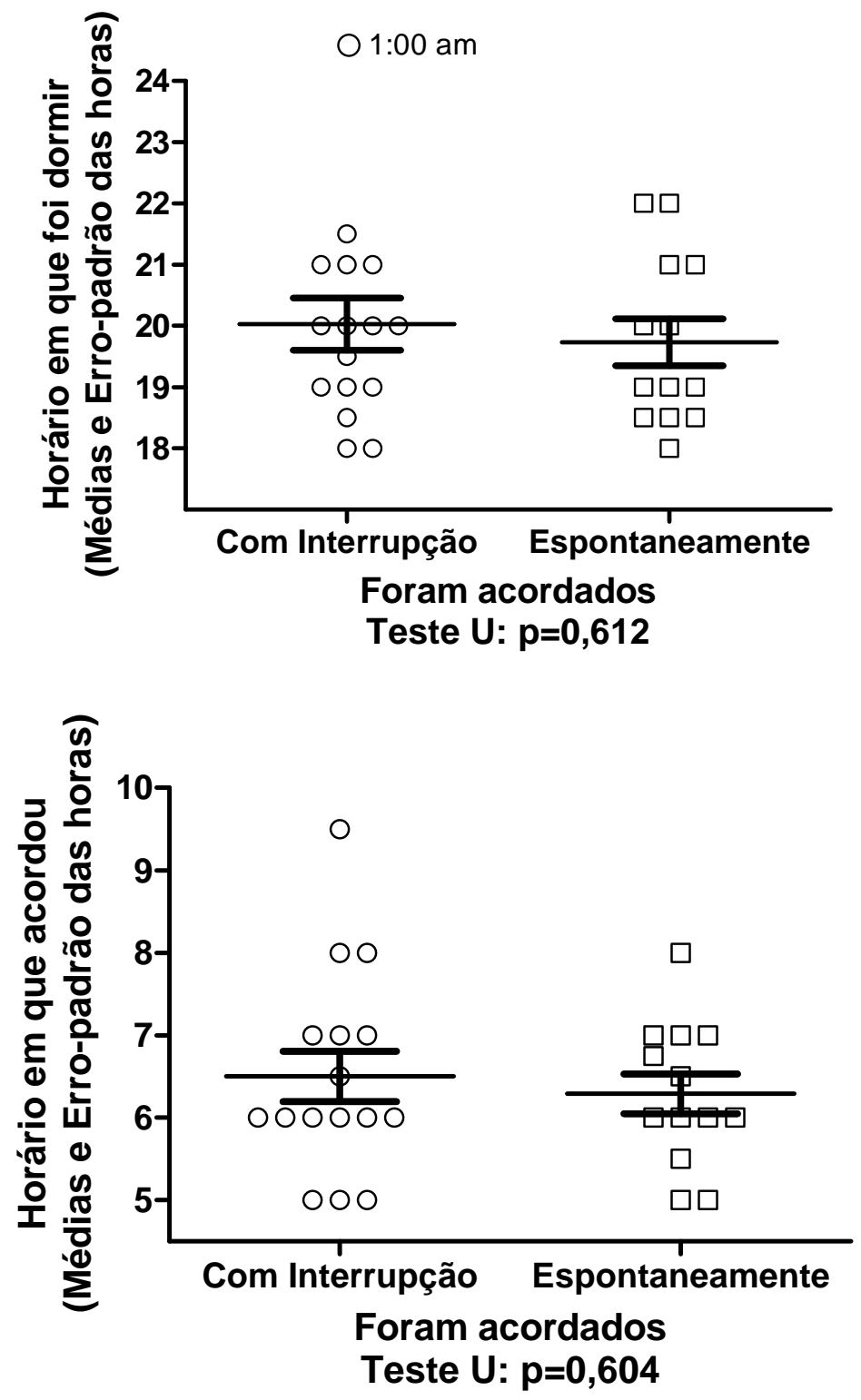

Figura 11. Distribuição dos horários que dormiram e acordaram em grupos diferentes (foram acordados ou despertaram espontaneamente).

Dezesseis participantes da amostra declaram cochilar e treze não. Na Figura 12, os idosos foram estratificados em dois grupos: um não cochilou e outro cochilou durante o dia. Estatisticamente, não se notou diferença entre os grupos, apenas uma leve tendência, aqueles que cochilaram são mais idosos. 


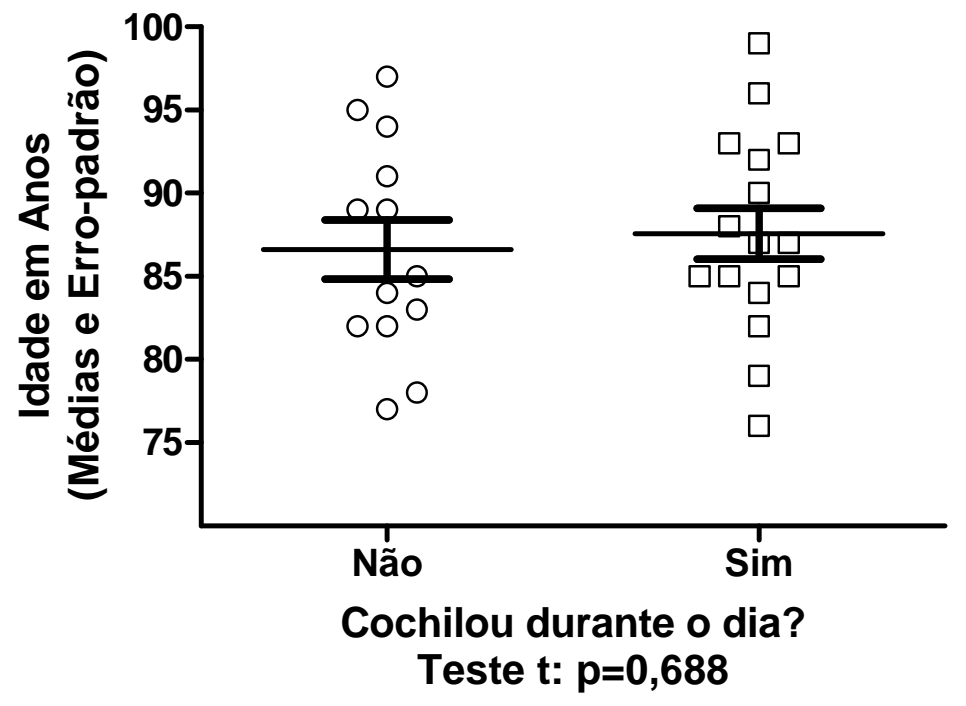

Figura 12. Idade entre os participantes de grupos diferentes (com cochilos e sem cochilos).

Quanto ao cronotipo, Figura 13, a pontuação foi analisada pelo teste $t$ de amostra independente, o resultado não se mostrou significativo, os grupos se apresentaram semelhantes. A média do Cronotipo dos sujeitos que cochilam foi 69,90 e dos que não cochilam foi 59,70 .

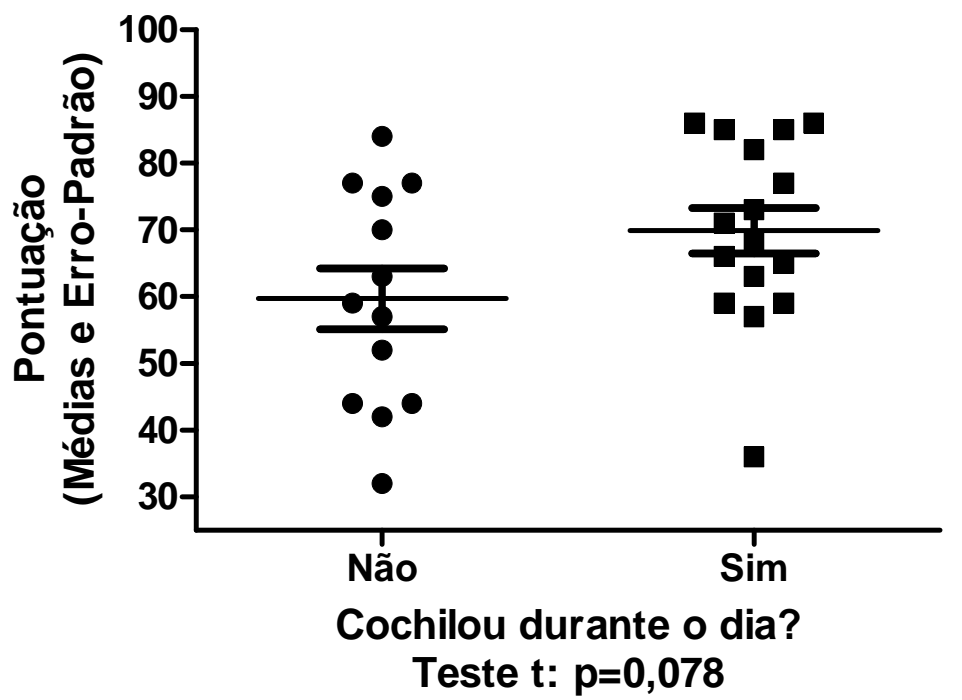

Figura 13. Pontuação entre os participantes de diferentes grupos (com cochilos e sem cochilos). 
.Foram realizadas comparações entre os que cochilaram e os que não cochilaram durante o dia e estatisticamente não foram identificadas diferenças entre os participantes da amostra estudada (Figura 14).
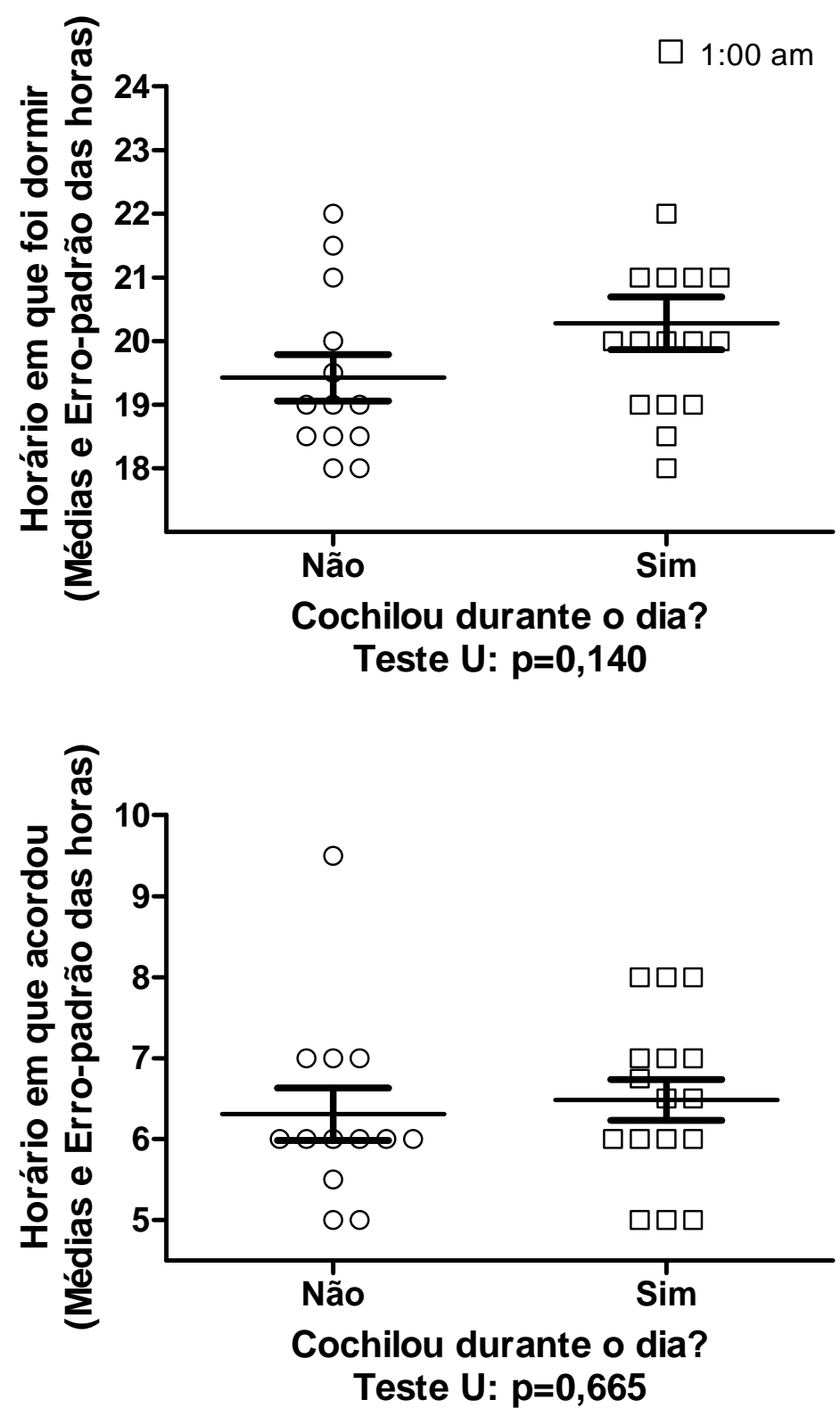

Figura 14. Distribuição dos horários que dormiram e acordaram em grupos diferentes (com cochilos e sem cochilos). 
$\mathrm{Na}$ Figura 15, pode-se observar que os horários de dormir e acordar, para ambos os grupos (cochilo e sem cochilo), apresentou significância ( $\mathrm{p}<0,001)$. Isso mostra que a amostra possui horários regulares de dormir e acordar. Porém as comparações entre grupos não foi significativa, apesar de ser possível observar diferenças entre os grupos cochilo e sem cochilo para os horários de dormir. Talvez um maior número da amostra pudesse realçar essa diferença.
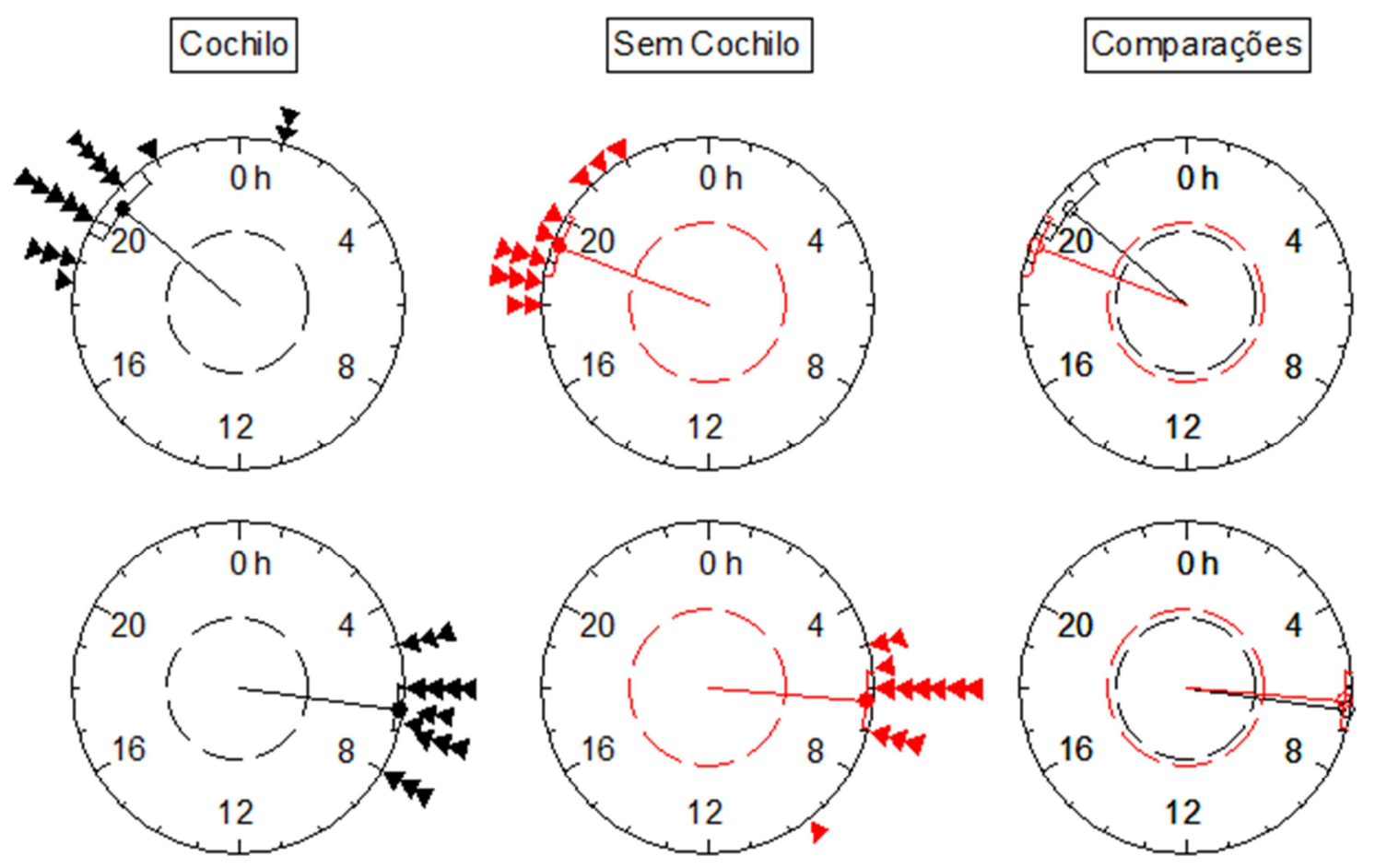

Figura 15. Horários entre os que cochilam e os que não cochilam durante o dia. 
4.7.3 Distribuição da pontuação que sugere sintomas de depressão entre os grupos

Entre as figuras 16 a 19, a pontuação na GDS-15 foi analisada entre os idosos estratificados em grupos. Estatisticamente, não se notou diferença entre os grupos.

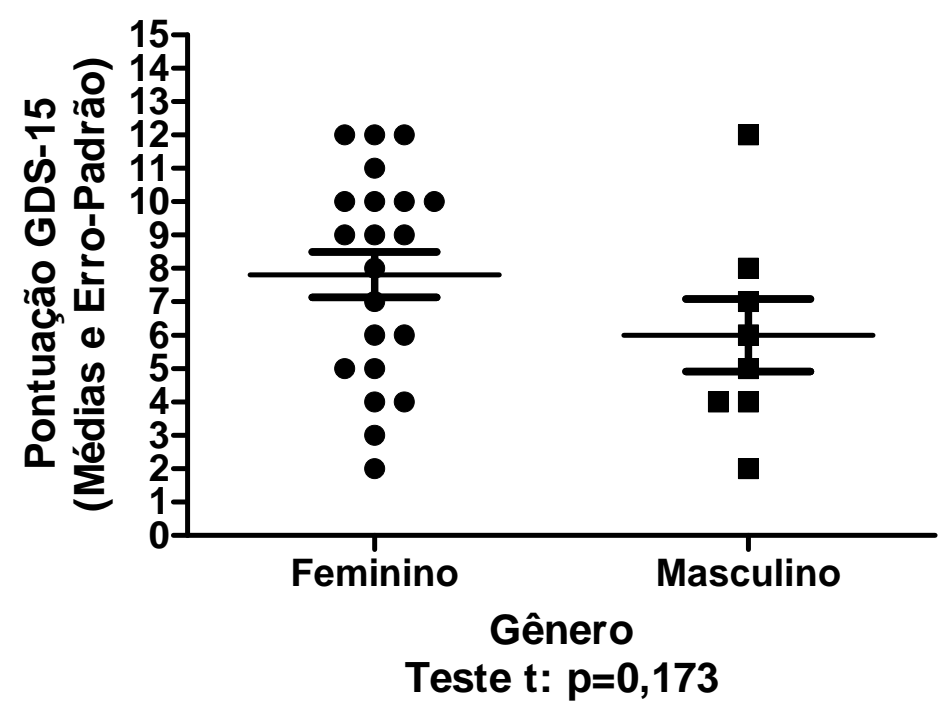

Figura 16. Distribuição da pontuação na GDS entre homens e mulheres.

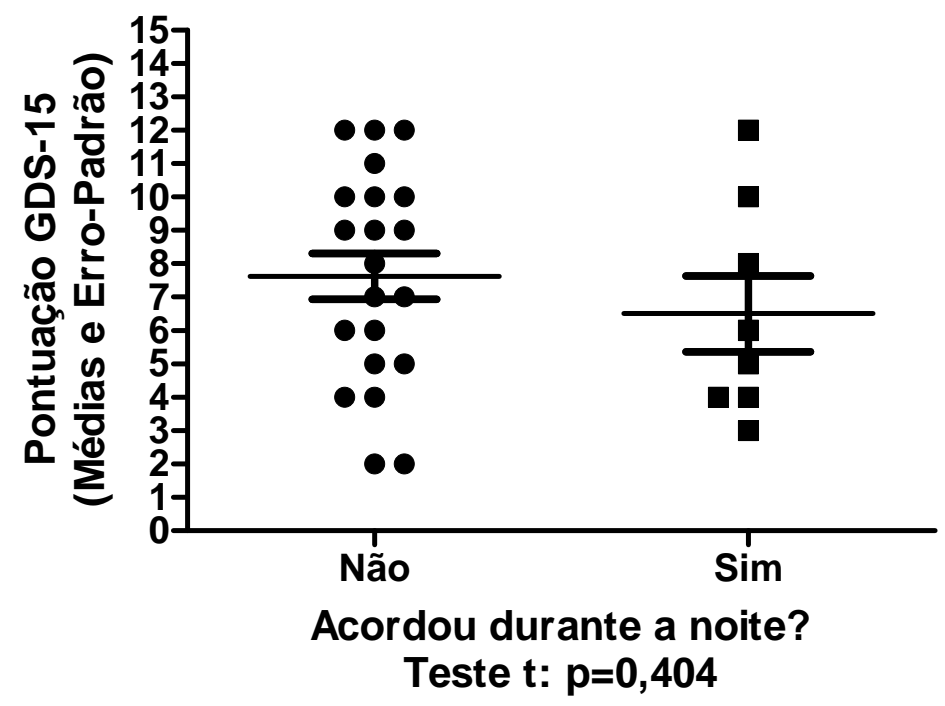

Figura 17. Distribuição da pontuação na GDS entre os participantes em grupos diferentes (acordar ou não acordar à noite). 


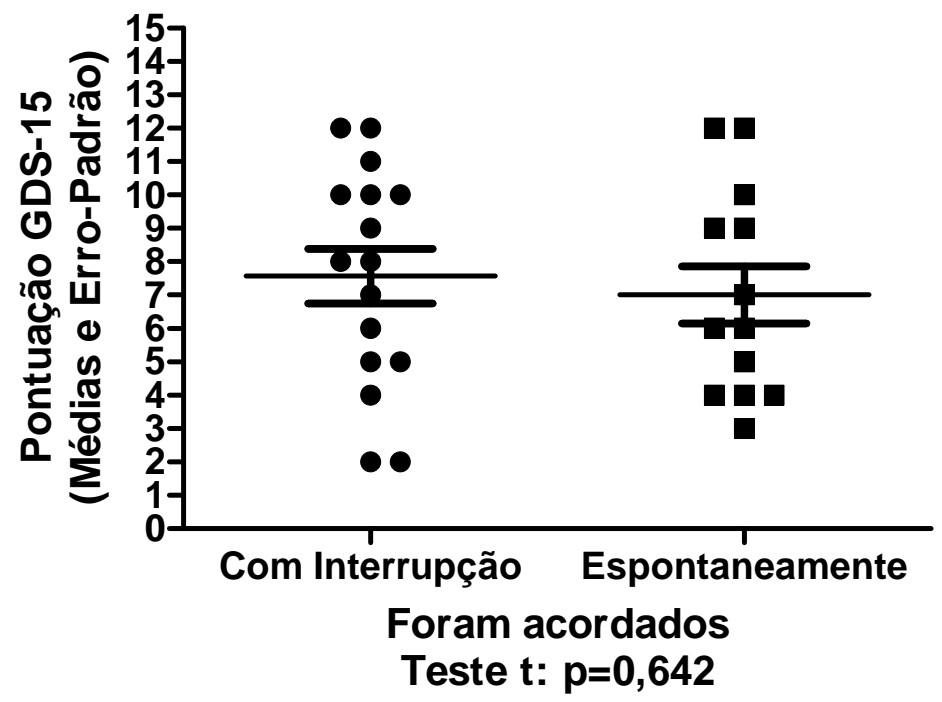

Figura 18. Pontuação na GDS entre os participantes de diferentes grupos (foram acordados ou despertaram espontaneamente).

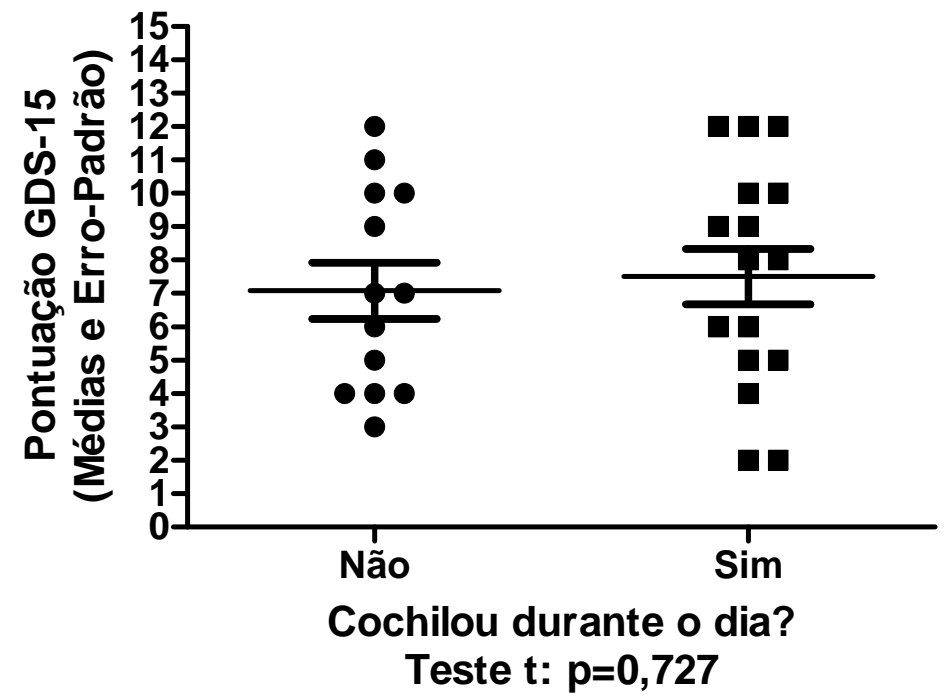

Figura 19. Pontuação na GDS entre os participantes de diferentes grupos. 


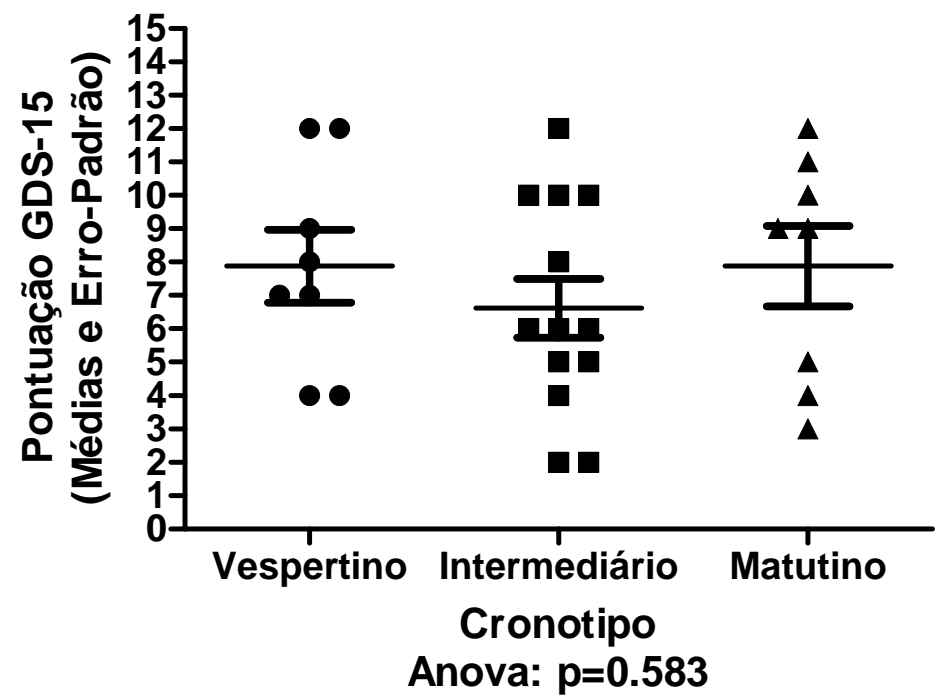

Figura 20. Pontuação na GDS entre os participantes de diferentes grupos segundo pontuação no teste do cronotipo.

4.7.4 Comparações entre cronotipo, horários de dormir e gênero

Foram também realizadas várias correlações entre o cronotipo e outras variáveis da amostra, as quais estão demonstradas nas Figuras 21 a 25 e comentadas a seguir.

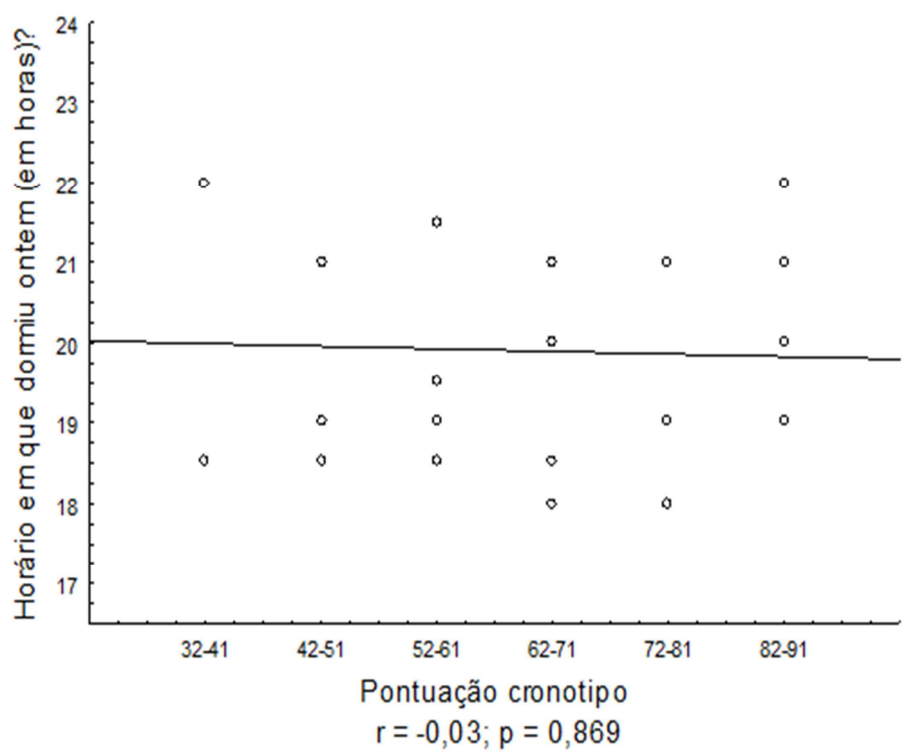

Figura 21 - Correlação entre horário que dormiu e cronotipo. 


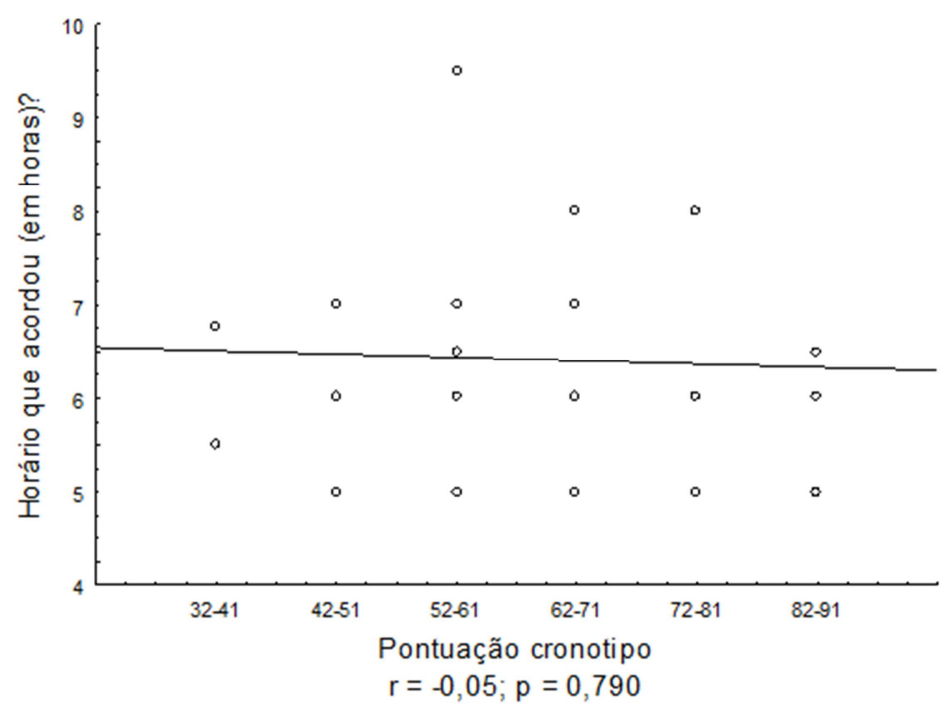

Figura 22 - Correlação entre horário que acordou e cronotipo.

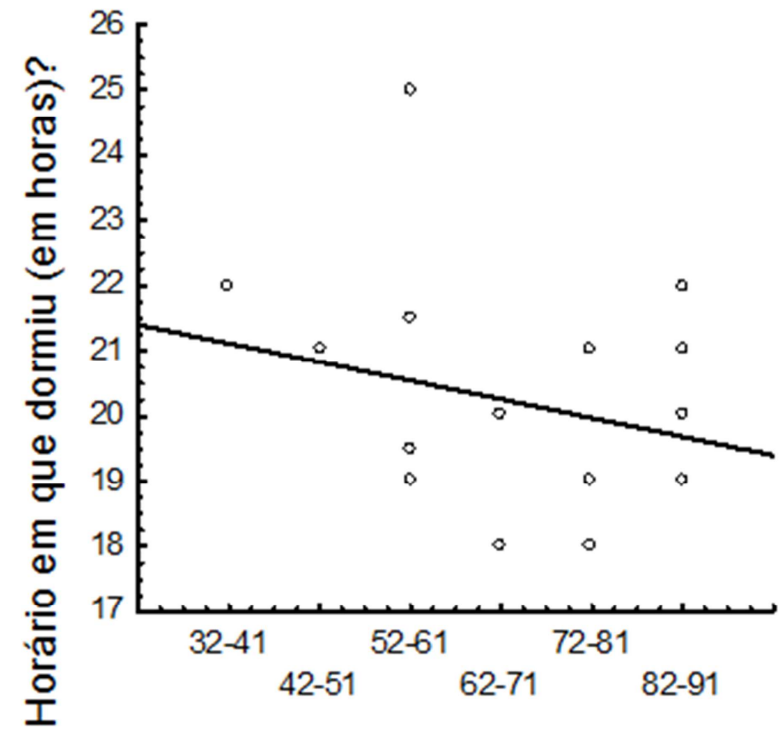

Feminino

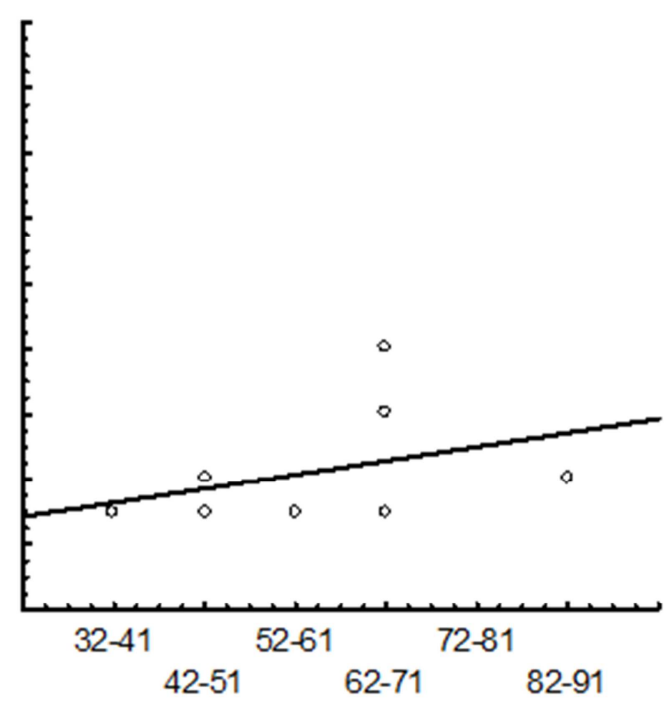

Masculino

\section{Pontuação cronotipo}

Figura 23 - Correlação entre cronotipos e horário em que dormiram os idosos institucionalizados, estratificadas por gênero: Feminino $(r=-0,25 ; p=0,275)$ e Masculino $(r=0,37 ; p=0,367)$ 


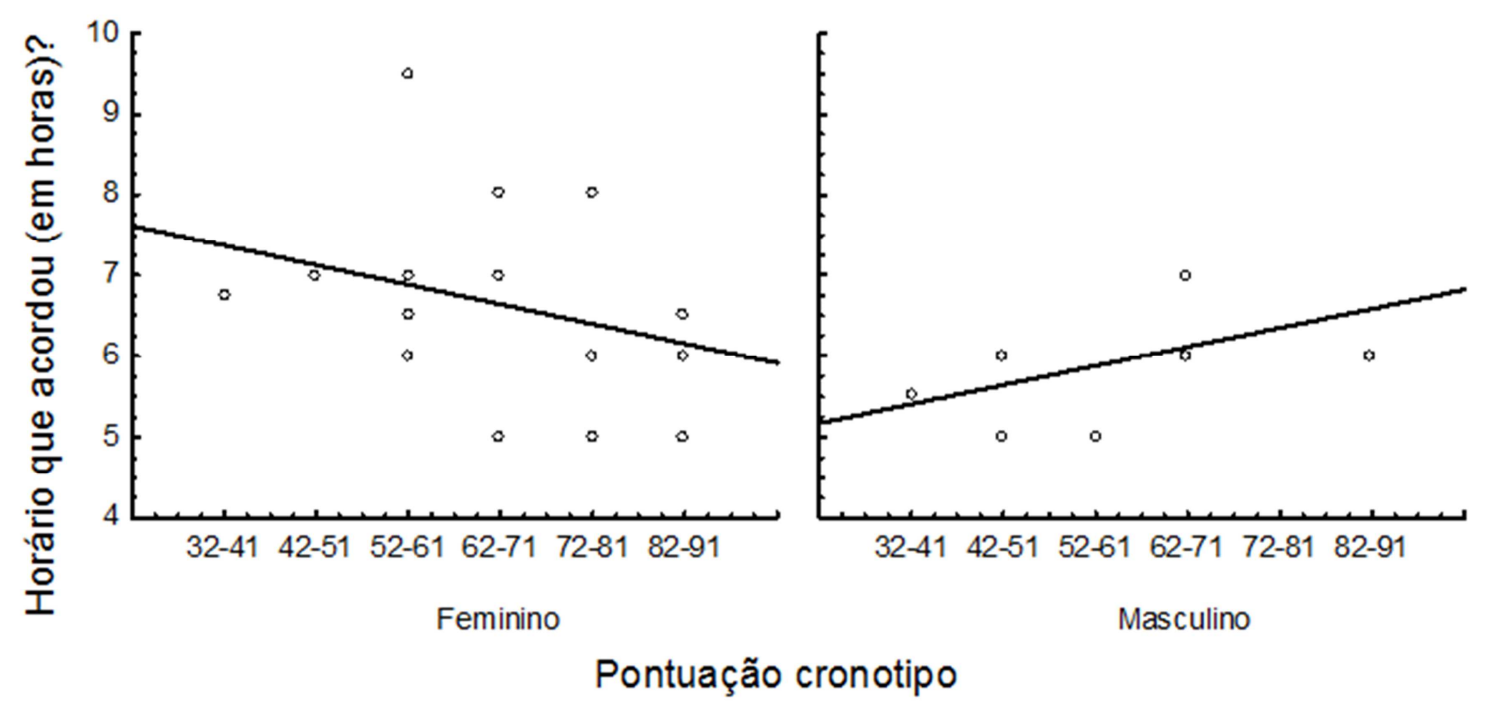

Figura 24 - Correlação entre cronotipos e horário em que acordaram os idosos institucionalizados, estratificadas por gênero: Feminino $(r=-0,31 ; p=0,166)$ e Masculino $(r=0,48 ; p=0,228)$.

O cronotipo não se correlacionou com nenhum das demais variáveis, o que nos leva a inferir que o dia-a-dia da instituição, com regras e horários para dormir e acordar interfira e padronize os hábitos de sono dos idosos, independente do seu perfil. Ao estratificar por gênero verificou-se uma tendência, não estatisticamente significativa, de que tanto as mulheres quanto os homens têm hábitos de sono compatíveis com o cronotipo matutino, porém, os homens são mais vespertinos, o que sugere que os mesmos podem ter sofrido uma alteração de seus hábitos de sono dentro da instituição, o que pode ser explicado pela pequena representação de residentes do gênero masculino na amostra estudada. Convém ressaltar que a amostra utilizada neste estudo foi por conveniência, ou seja, participaram os residentes acessíveis, de acordo com os critérios de inclusão: consentimento e estar cognitivamente preservado, ou com leve comprometimento cognitivo. $\mathrm{O}$ fato da escolha não ter sido feita por meio de um critério estatístico representa uma maior facilidade operacional, no entanto, não nos permite fazer afirmações gerais com rigor estatístico sobre a população. Mostra apenas uma tendência, o que aponta para novas possibilidades de ampliação do estudo com uma amostra mais ampliada. 
4.8 Análise das entrevistas e das observações

A seguir apresento os temas e os discursos que foram coletados nas entrevistas gravadas que servirão para complementar os dados dos demais instrumentos de pesquisa. Os dados das entrevistas serão permeados pelas anotações do diário de campo que foi construído ao longo de todas as visitas, principalmente na segunda instituição, na qual continuei utilizando a técnica da observação participante e segui observando e anotando tudo o que me foi possível, mesmo após a coleta de dados de protocolos no local.

Procurei estar atenta aos detalhes e às expressões, atentando para os aspectos que normalmente passariam despercebidos. A observação participante permite as experiências interna e externa de uma situação social e o trabalho de campo etnográfico envolve a alternância entre elas (Spradley apud Correia, 2009). Além disso, ao fazer a investigação dos fatos observados e das pessoas nas instituições e mesmo neste ponto de proceder à análise dos relatos coletados, procurei ter em mente o que Velho (2008) recomenda, que é manter certa distância para conseguir uma investigação imparcial, ou pelo menos tentar esta imparcialidade. Como tive um bom tempo de convivência nos locais acredito ter conseguido o que o autor chama de identificar aspectos menos explícitos da cultura local. Em seu texto “Observando o Familiar", Gilberto Velho afirma que estar familiarizado não significa que conhecemos todos os pontos de vista dos envolvidos, nem todas as regras praticadas naquele local aparentemente conhecido. Muitas vezes conhecemos apenas superficialmente aquela rotina e não somos bem sucedidos por fazermos julgamentos apressados, por isto, com um tempo maior de observação essas interpretações passam a ser mais coerentes com a realidade daquele local, mas ainda assim estarão carregadas da subjetividade do observador.

Ao analisar as falas procurei não levar em consideração qual pessoa produziu determinada fala, pois para a análise de discurso, o que importa não é quem diz, mas a partir de que lugar fala. Os participantes, nessa abordagem, não produzem suas enunciações de acordo com um sentido por eles pretendido. Segundo Pêcheux (2002) os sentidos se produzem a partir da tríade sujeito-linguagem-história, ou seja, dentro de um contexto mais amplo. Segundo o autor, neste tipo de análise não interessa procurar as intenções dos indivíduos ao formular determinado enunciado, mas sim de analisar de que posição qualquer pessoa teria esse mesmo discurso.

A proposta da Análise do Discurso consiste em "ver além das aparências", ou seja, detectar no discurso não apenas os conteúdos conscientes, mas também os inconscientes. Mas minha indagação era: como proceder para tornar isto possível? Uma forma encontrada foi 
analisar as falas e agrupá-las em temas discursivos, buscando os fragmentos de texto que se relacionam com esses temas.

Os tempos sociais praticados nas instituições asilares nas quais fiz minha pesquisa refletem que ela é realmente uma organização centrada no trabalho. Com esta ideia central, as rotinas são definidas, são estabelecidos os plantões dos profissionais, bem como o cotidiano dos residentes. Resgatando a ideia de Oliva-Augusto (2002) sobre a ordem social centrada no trabalho definir a sua dinâmica, foi possível reconhecer nos relatos coletados e nas observações anotadas aquilo que a autora menciona como o trabalho e o tempo de trabalho como identificadores de tempo para eles.

Recorrendo ainda às ideias de Braga (2008) e Russel (1935) de que as pessoas se sentem entediadas pela ociosidade, o que provoca a sensação de inutilidade, percebi que isso é bem presente. Já o que Rolant (1987) sugere de que o tempo de ociosidade não deveria ser encarado como um tempo perdido, mas sim que ele poderia ser utilizado em outras coisas mais importantes para a própria pessoa e principalmente para o coletivo, não foi observado. Dentro dessa linha, descrevo a seguir alguns relatos coletados sobre a rotina na instituição, que em alguns casos repete a rotina dos lares de origem:

“Aqui tudo é marcadinho e a gente já sabe cada coisa que vai acontecer... quando as enfermeiras pegam no serviço começa a rotina para nós também”.

"a vida aqui é muito igual todos os dias, a gente fica parada e espera as coisas que vêm dos que trabalham... ah, mas era igual em casa também porque a gente não trabalhava mais...”.

“se a gente não tem que trabalhar o que mais vai fazer? É um tempo meio morto... fazer o quê?? Não tem graça...é só esperar”.

Embora os relatos analisados quase não revelem o que Certeau (1998) denomina fraturas na ordem imposta para burlar as normas, encontrei alguns discursos que estão em linha com essa ideia: 
"Aqui é bom, é como uma casa... a gente dá um jeitinho com as coisas... consegue sentar num lugar melhor, uma bolachinha a mais... ficar um pouco mais na cama... na base da conversa."

Relato de uma residente sobre a vantagem de ser cordial com as profissionais.

"Ninguém explicou nadas das regras... a gente vai sabendo quando vai acontecendo, a gente vai vendo conforme o plantão das enfermeiras, cada uma dá o seu jeitinho...”.

Uma residente referindo-se a ser solícita para ajudar as profissionais.

"Por que você não diz que está precisando muito ir ao banheiro?... assim elas te levam-no banheiro e de lá você pede para ir dormir...".

Conversa anotada no diário de campo entre uma mulher e um homem que estava querendo ir para a cama dormir antes que os outros e queria tentar ludibriar as enfermeiras (obs.: eram 18 horas).

Acredito que, apesar dos poucos relatos anotados, estas falas não são únicas e que haja outras formas que os residentes e mesmo os profissionais se utilizem como táticas do dia-adia para resistir, mas que não consegui observar.

Tanto na observação participante, quanto em algumas entrevistas, apareceu a necessidade de existirem regras, no sentido do que Durkheim (1972) define como uma forma de dar segurança e proteção à instituição, conforme relatado a comentário de um profissional com um familiar:

"aqui tem que ter horário e regras para tudo... senão os residentes ficam desorientados... aqui eles sabem das coisas pela rotina de refeições, banho, sono".

"acho bom ter regra sim e quem não se adaptar vai embora... ninguém é obrigado a nada".

Comentário de um residente na entrevista sobre a imposição de horários na instituição.

Existem discursos se contrapondo à imposição das regras, ou mesmo demonstrando a ideia de disciplina que, segundo a definição de Foucault (1996), representa o sistema de poder, que os profissionais exercem sobre os residentes, conforme mencionado em conforme coletado nas entrevistas de alguns deles: 


\section{“... aqui quem manda são as enfermeiras!” \\ "gostar a gente não gosta, mas fazer o quê, não é?" \\ "eu como bem, faço tudo direitinho como eles mandam”.}

Em muitas ocasiões em que estive nas visitas, tanto entrevistando, quando somente à época da observação selvagem, muitas cenas me fizeram reconhecer o que Elias (1993) define como o número pouco expressivo de cadeias entrelaçadas de ação, ou seja, momentos em que os residentes e os profissionais estão fazendo alguma atividade, porém, é como se lá não estivessem, o que parece caracterizar o que Palmeira (2001) chama de tempo da eternidade, que é a lacuna existente entre essas cadeias entrelaçadas de ações diárias tão pouco expressivas. A seguir transcrevo duas observações que demonstram essas ações.

Cena 1: Nove pessoas na sala, 7 homens, 2 mulheres; televisão ligada, volume muito baixo; 5 cochilam, duas olham para a TV... olhar perdido sem prestar atenção; novela do final da tarde; duas auxiliares dão comida na boca de residentes que não conseguem comer sozinhos; as duas vão colocando as colheres de comida na boca deles, mas com olhar fixo na novela; os que estão comendo olham para o chão; esperam a próxima colherada de comida e esse tempo parece longo; silêncio; cochilos; novela.

Cena 2: Instituição que só abriga mulheres: 13 residentes na sala; cada uma tem o seu lugar demarcado; uma televisão de 29 polegadas ligada; som baixo; só é possível enxergar a imagem estando sentada ao lado, mas três olham para a TV à distância, estaticamente; 8 cochilam; duas brincam com as próprias bengalas, riscando o chão; duas atendentes fazem relatórios; eu olho para todas, mas elas não me veem; parece que o tempo parou; só uma quando fui sair me pergunta: você vai escrever um livro?

No trabalho de Groisman (1999) em que ele estudou a implantação do primeiro asilo no Brasil, ele faz a referência à comparação entre a velhice e a infância, ora mostrando as diferenças entre as duas fases, ora as semelhanças, quando a dependência física ou mental do velho o iguala a uma criança. Ele denomina a forma como é vista esta situação como "segunda infância" que justifica um tratamento infantilizado, conforme observei em uma das visitas.

Uma auxiliar fala com uma mulher que está cochilando, fala como se ela fosse uma 
criança: "ai que judiação da minha belezinha, tá com soninho? Vou trazer a cobertinha”.

Este fenômeno é chamado infantilização da velhice, um estereótipo comum de tratamento desigual em função da idade. Segundo Couto (2009) a comunicação de forma paternalista, vagarosa e simplificada pode causar impacto negativo sobre as pessoas mais velhas. Mas é interessante citar que muitas vezes entre os velhos há uma concordância com essa crença ao se referirem ao tratamento recebido nestes termos, sem uma crítica. Talvez por acreditarem que as auxiliares são "boazinhas para eles" torne essa linguagem natural.

“elas tratam a gente bem aqui... é vovozinha pra lá, vovozinha pra cá... come tudinho pra ganhar o docinho depois... é que a gente não pode devolver o prato cheio, sabe?”

Resgatando a colocação feita por Neri (2007) de que, mesmo na velhice não nos reconhecemos velhos, cito uma fala de uma residente entrevistada, cuja idade é 89 anos:

“Mas pra mim até que está bom, eu estou há bastante tempo aqui... às vezes eu fico olhando as velhinhas que têm aqui... velhinhas porque tem 95, 97 anos... e eu penso, meu deus eu podia morrer agora. Eu olho pra os outros que estão dando trabalho e penso não quero dar trabalho para ninguém”.

Nesta fala e em outras parece que a noção de velhice está associada a estar com demência, muito mais do que dependência física, como era o caso desta residente.

Encontrei poucos casos que se enquadram na afirmação de Clos (2010) de que para muitas pessoas viver numa casa de repouso pode significar uma alternativa melhor do que viver nos seus lares de origem, mas acredito que muitas pessoas que relatam que sua vida era melhor, que se davam bem com a família, etc. podem não estar retratando o que na realidade ocorria, mas que de fato as pessoas "criam" essas memórias de felicidade idealizada.

“'Pra mim aqui não tem nada de regras obrigatórias, pois levanto a hora que quero... na hora certa vem a comida, café, tudo. Sabe, eu posso pedir as coisas paras as enfermeiras, eu fico num quarto particular, é diferente.”

"A hora do almoço é boa pra mim... tudo prontinho na mesa... pra quem teve que fazer isso pros outros a vida toda, eu acho uma maravilha!... e se a gente elogia também agrada as moças e até consegue um tratamento especial." 
Em todos os momentos em que as enfermeiras precisam fazer algum procedimento ou mesmo ao trocar as roupas das pessoas foi possível notar que as pessoas se colocam numa posição de aquiescência, docilidade, mesmo diante de algum recato em relação ao corpo ou mesmo a algum procedimento incômodo quando precisa fazer algum deslocamento, por exemplo. Em alguns relatos também percebi esta ação de "entrega" diante da situação que se apresenta, o que está em conformidade com a ideia de Foucault (2004) sobre a docilização dos corpos, que em geral vem acompanhada do resignar-se a expor seu corpo Le Breton (2011).

“Como estou há bastante tempo pra mim não tem regras, posso dormir a hora que quiser, mas acordar acordo cedinho pras enfermeiras arrumarem a gente, porque vem o outro plantão às 7. Elas querem deixar a gente limpinha pras outras e a gente ajuda elas. Mas aqui ninguém me falou você tem que fazer isto, aquilo.... mas a gente precisa ajudar as meninas.”

“Meu sono é leve... tudo me acorda... de manhã então às 5 começa a rotina. É barulho, é luz, é gente pedindo pra levantar, são as enfermeiras querendo ir ajeitando a gente pro turno novo... elas querem deixar a gente certinho pra escrever no caderno. A gente ajuda e deixa elas fazerem o que precisa com a gente, porque elas têm que entregar a gente limpinho para o outro plantão."

Considerando que os residentes trazem a experiência do tempo marcado pelo relógio que sempre pautou seus horários de trabalho, nas minhas análises considerei os estudos de Thompson (2005) sobre o controle do tempo nas relações de trabalho que são questões culturais que envolveram tanto os residentes ao longo de sua vida quanto os profissionais que ali trabalham. Percebi que os residentes falam sobre sua percepção do "passar do tempo" na ociosidade em contraste com o que fizeram em sua vida "gastando tempo" no trabalho (Thompson, 2005) e isto influencia a sua sensação de inutilidade. Este pensamento se observa também nas mulheres que não trabalhavam fora de casa, porém, suas tarefas rotineiras eram ritmadas pelo tempo dos homens. Os discursos ressaltam bem o conceito de improdutividade, que ainda segundo o autor, consagrou a expressão "passar o tempo à toa" como contraposição com o gastar o tempo produzindo. 
'Antes de vir pra cá, trabalhava em casa mesmo, fazia as coisas... os horários sempre eram como nos tempos de trabalho... não precisava, mas era igual quando todos trabalhavam.",

“As pessoas trabalhavam e a gente que não trabalhava seguia a rotina deles... afinal o trabalho é que manda. Mas eu dormia um pouco mais tarde, mas conseguia acordar cedo pra rotina... dormia pouco mesmo... hoje também durmo pouco... a gente vai ficando mais velho é assim.",

“'Aqui chama casa de repouso, mas é chato a gente ficar sem fazer nada, passando o tempo à toa... Sem poder trabalhar a gente é inútil, não serve pra nada... é que a gente não aprendeu a fazer nada... só trabalhar.",

“Tenho relógio... não preciso, mas é costume. Fico olhando toda hora... não adianta porque sei que o tempo vai demorar a passar. Mas olha, quanto eu ficava em casa, eu também achava isto. Só não lembro como era quando eu era mais nova.”

Observando as relações entre as residentes da instituição que só recebe mulheres pude observar o que Melucci (1989) chama de conflito entre as residentes lutando pelos mesmos recursos, ora por um mesmo espaço físico para se sentarem, ora pelo uso do banheiro coletivo, que geravam discussões e muitas animosidades entre elas. Mas também notei o sentimento que o autor chama de solidariedade, ou seja, momentos em que elas partilharam uma identidade coletiva. Isto se deu em ocasiões em que as pessoas eram colocadas nas instituições contra a sua vontade e estes momentos de solidariedade à nova residente as uniam pelo fato de se reconhecerem na mesma situação, conforme diálogo a seguir:

$$
\begin{aligned}
& \text { “- me deixaram aqui e foram embora, não quero ficar; } \\
& \text { - depois a gente acostuma... } \\
& \text { - não vou acostumar coisa nenhuma } \\
& \text { - aqui a comida é boa } \\
& \text { - eu não vim aqui pra comer } \\
& \text { - aqui as moças são boazinhas e a gente te ajuda } \\
& \text { - não sou conformada igual vocês não!” }
\end{aligned}
$$


Uma situação que me intrigou e que confirmou meu questionamento sobre as instituições colocarem num mesmo ambiente pessoas com os mais diversos graus de complexidade, foi o relato de uma das entrevistadas se referindo a ter que passar a maior parte do seu tempo na sala de convivência. Nas diretrizes de funcionamento para as instituições para idosos (Brasil, 2005), uma das recomendações é que a instituição deve promover a convivência mista entre os residentes de diversos graus de dependência, mas o convívio diário torna-se um fator complicador, conforme ela me relatou:

"Nesta sala com toda esta gente misturada... olha as pessoas não conseguem mais nem ficar sentadas, nem andar, outros falando alto, olhos perdidos, babando... para todo lado que a gente olha é isto... e a gente vai ficando, sei lá... é o tempo todo só vivendo isto... como você acha que a gente vai ficando?"

Com base em um relato que colhi de uma das enfermeiras, fui buscar alguma pesquisa que comentasse sobre o fato e encontrei uma importante questão levantada por Robertson (1990), para a qual precisamos estar alertas. Ele cita como "demografia apocalíptica" o desfilar de números que são apresentados em pesquisas para justificar algumas intervenções de profissionais da área da saúde e ele dá o exemplo do que tem acontecido com a Doença de Alzheimer e que ele entende ter sido transformada em epidemia, abrindo extenso campo para intervenções de toda natureza. Ele vai mais longe, perguntando se não estamos criando uma epidemia de diagnósticos e sobrevalorizando a biomedicalização do envelhecimento. Isto me levou a fazer uma analogia com a epidemia de casos de crianças diagnosticadas com hiperatividade há algumas décadas, levando a tratamentos medicamentosos e diversos profissionais envolvidos, tudo para colocar a criança dentro da normalidade. E atualmente se reconhece que em muitos casos houve medicalização desnecessária da infância e que o procedimento deveria ser revisto. Precisamos estar sempre atentos para estes fatos históricos, nós que estudamos o processo de envelhecimento.

Neste contexto, cito o depoimento espontâneo de uma enfermeira obtido nas minhas visitas de observação. Ela estava contente em trabalhar naquele local, pois a aconselharam a vir para São Paulo em busca de trabalho em casas de repouso:

"Vim para São Paulo, porque me disseram que aqui tinha muito emprego para trabalhar com idosos. E é verdade mesmo, arranjei emprego rapidinho, achei engraçado pois lá na 
comunidade de onde eu vim, no Mato Grosso, tem muitas aldeias indígenas e também tem muitos idosos, mas não tem Alzheimer. Lá eles quando ficam um pouco esquecidos as pessoas não chamam de doença, ninguém trata com medicamentos, nem tem trabalho pra gente cuidar deles por causa disso... e não é pobreza não... é assim mesmo lá”.

Não tenho interesse neste trabalho entrar para esta discussão, mas é sempre aconselhável tomarmos cuidado para não nos apoiarmos em estatísticas catastróficas para justificar a nossa importância social.

\subsection{1 - Relato de cenas presenciadas}

A seguir descrevo algumas cenas presenciadas ao longo das visitas, as quais me marcaram bastante e que foram anotadas durante as etapas de observação selvagem e participante.

\section{> Cena 1 - Silêncio e calmaria após empolgante atividade musical}

Em uma das visitas não pude entrevistar as pessoas com quem iria falar, pois coincidiu com uma atividade musical apresentada por um cantor de músicas sertanejas. O cantor era muito comunicativo e conseguiu uma boa participação dos residentes que cantavam, acompanhando a letra das músicas (exercício de memória) e batiam palmas no ritmo, interagindo e trocando olhares cúmplices entre si (interação social). Após sua apresentação o cantor se despediu e saiu. Exatamente no instante seguinte todos voltaram ao silêncio, olhando para o nada, como se nada tivesse acontecido no local.

Ao sair dali fiquei refletindo sobre o ocorrido e concluí que existe um ânimo e uma capacidade de reação das pessoas aos estímulos que lhes são oferecidos, mesmo essas que vivem uma situação de apatia quase que generalizada no dia-da-dia, a partir de um fato motivador, se transformaram, olharam-se e se sentiram felizes. Ou seja, é possível reinventar trajetórias sociais e criar novas redes sociais nesse novo ambiente como afirmam Rocha e Eckert (2000). Ainda dentro desse contexto trago um depoimento em uma entrevista onde uma mulher descreve a transformação de outra residente quando participou desta atividade pela primeira vez: 
"Tem uma senhora que o filho dela ficou nervoso e falou: "mãe a senhora só dorme? Dorme sentada, dorme na cama, só dorme?"e ela no dia que veio o cantor, foi a primeira vez que ela viu o cantor, como ela estava alegre, como ela se sentiu alegre, ela falou: "nós temos que preparar alguma coisa para quando ele vier, para ele tomar, para ele depois que ele tocar ele se sentir bem”, agora já pensaram assim, vamos comprar sorvete, vamos dar sorvete para ele... A que estava dormindo, acordou porque teve uma atividade alegre... Sempre triste, sempre triste, agora está alegre, assim é que conheci ela”.

\section{Cena 2 - A entrada forçada de três pessoas novas na instituição e sua reação}

Pude presenciar duas mulheres e um homem serem trazidos para as casas de repouso, sem que eles quisessem. Em um caso a pessoa precisava de cuidados constantes, pois havia sofrido uma queda e estava imobilizada. Aí a entrada foi mais tranquila e ela falou para as demais, após os parentes irem embora, que iria sair logo... que estava de passagem... quando ficasse boa, iria embora. Mas ao voltar a andar percebi que ela continuou lá. Por isto não criou uma relação de moradia, mas de passagem, o que não favorece em nada a criaçao de vínculos. O homem entrou sem falar nada, ficou sentado, não se despediu e nem olhou para ninguém, assim ficou durante os meses em que estive lá. A terceira mulher reagiu, gritou, xingou a filha, xingou as enfermeiras que a trouxeram para dentro. Recebeu solidariedade das demais, mas não aceitou. Porém, após alguns dias, passou a participar das atividades e a comer. São três casos bastante comuns que podem levar os profisionais a verem a pessoa ora com piedade, ora com indiferença diante da forma como os familiares conduzem as admissões.

\section{$>$ Cena 3 - Como foram tratadas as mortes de residentes}

Pude constatar bem o que Elias (2001) fala sobre negarmos o processo de morrer, tratando de ocultá-la e silenciar. Houve três residentes que morreram durante o tempo das minhas visitas. Percebi que os demais não comentaram o fato e os profissionais evitaram mencionar também. A explicação é que a pessoa tinha ido se tratar e que demoraria para voltar. Em um dos casos era uma residente muito antiga que conversava e 
conhecia todos e que sempre que eu estava lá me chamava para mostrar seus trabalhos manuais que fazia para vender. Quando perguntei pela Dalva a proprietária da instituição disse que ela havia falecido, mas que não era para comentar, já que ninguém tinha sentido falta dela, o que constatei ao conversar com uma pessoa que me disse "nossa, nem tinha percebido... acho que ela resolveu ir embora".

Mas será que o não perceber foi apenas uma forma de negar e silenciar sobre a morte? Esta questão não foi colocada, tendo em vista que minha presença ali tinha o objetivo da pesquisa, portanto, não havia receptividade para influenciar ou questionar o modo de proceder nos casos de luto. Caso eu tenha abertura ao término do trabalho, considero que esta é uma das questões que merece atenção, caso minha participação na rotina seja permitida. Visto que sabemos que há várias formas de elaborar o luto, homenagear a pessoa, fazer uma cerimônia, ou seja, não apagar a pessoa, mostrar que ela tinha valor dentro da comunidade.

Para concluir esta fase do percurso analítico, informo que os fragmentos discursivos apresentados foram analisados segundo o que Orlandi (1999) define como estudar não a língua ou a gramática, mas a palavra em movimento no contexto social em que ela se dá. Mesmo encontrando dificuldade de manter a neutralidade nas interpretações busquei atingir uma melhor qualidade de análise nas fundamentações teóricas nas quais me baseei. Procurei estar atenta para ter sempre presente o tema dos tempos sociais das instituições e dos tempos biológicos dos residentes, mas seria uma tarefa impossível separar questões temporais de todo esse universo de relações sociais que teve que ser considerado para enriquecer este estudo.

\subsubsection{Aproximações e distanciamentos entre as duas instituições pesquisadas}

Ao ter a oportunidade de conhecer mais profundamente uma segunda instituição na qual me inserir, procurei aproveitar a oportunidade para melhor compor a minha pesquisa, buscando observar o que as aproximava ou distanciava. Em uma das instituições o um valor da mensalidade é bem mais elevado em comparação à outra. Na instituição cujas mensalidades são mais altas, a rotatividade dos profissionais existe, mas é menor. A estrutura das casas e os dormitórios são mais amplos e equipados com itens de segurança. A incidência de quedas, do meu conhecimento, foi relativamente baixa. Já na segunda instituição pesquisada, cujas mensalidades são mais baixas, a rotatividade de profissionais é muito alta, 
os locais de permanência durante o dia têm seus espaços destinados exatamente ao número de residentes, sendo que algumas permanecem num hall da recepção. $\mathrm{O}$ índice de quedas é alto e o número de pessoas com problemas respiratórios que levam a hospitalizações é grande. $\mathrm{O}$ quadro de cuidadoras é insuficiente em face da demanda, provocando um cansaço observável em suas fisionomias.

Porém, essa questão dos preços é irrelevante quando se observam as semelhanças, ou aproximações entre ambas, pois as salas coletivas reúnem uma porção de solitários. As rotinas locais são empobrecidas; não existem iniciativas de criar um grupo, um coletivo. A televisão é um entretenimento presente desde o início do dia, mas fica distante e com som baixo o que não permite que se possa acompanhar algum programa, a não ser observando as imagens. Exceção feita à segunda instituição que mantém uma terapeuta ocupacional fixa, remunerada e que trabalha no local há mais tempo que as demais profissionais e que conseguiu criar vínculos com as residentes. Em nenhum dos locais é tratado o tema finitude e ninguém participa da despedida de um residente quando é internado ou quando vem a falecer. A morte do outro fica no esquecimento. Em geral o estado de apatia é presente em ambas, os cochilos durante o dia todo são comuns, a hora de dormir parece que representa um alívio e as pessoas querem antecipar. Poucas atitudes revelam que as pessoas têm algum apreço pelo local e poucas conversam entre si, a não ser para brigar por causa do barulho, por roubar o seu lugar no sofá, criando episódios de violência, mesmo na residência que só admite mulheres. Há uma ligeira vantagem nesta que só aceita mulheres, pois elas sentem mais liberdade, o que as mulheres da outra casa reclamam é terem que ficar tão próximas, misturadas com homens que nunca viram na vida. Em nenhum dos dois locais a crítica às regras temporais é evidenciada, aliás, as análises críticas em geral são tímidas. As visitas de familiares significam um momento de alegria para muitos, porém, não percebi o partilhar da presença com outros residentes que recebem poucas visitas.

O tratamento das profissionais com os residentes em geral se restringem aos cuidados de higiene e alimentação havendo, no entanto, várias auxiliares que trabalham por amor à profissão. Em geral percebe-se que o tratamento dos residentes para com as profissionais é sempre cordial e de agradecimento, mas com poucas evidências de que se sintam em uma relação afetiva, mas sim de inferioridade. 


\section{Hipótese}

Ponto de partida

Em instituições asilares para idosos, em geral, não são levadas em consideração as preferências individuais de horários para atividade-repouso dos residentes. Ter que seguir um regime temporal homogêneo pode causar impactos negativos nos seus ritmos biológicos, principalmente sobre o ciclo vigília/sono. Isso pode afetar negativamente o seu estado de humor, colaborando para o declínio em seu desempenho cognitivo. A não consideração das preferências pessoais pode colaborar para reforçar a ideia de que viver em uma instituição asilar não representa o local de moradia das pessoas, mas sim uma hospitalização por tempo indeterminado.

Ponto de chegada

Parti da hipótese de que se houvesse a consideração das preferências pessoais de horários, ou seja, o respeito aos ritmos diários dos residentes, isso seria determinante para melhorar $o$ viver na instituição asilar. E, conforme está em nosso imaginário, considerei que testar a minha hipótese seria apenas seguir em busca da sua confirmação, ao invés de considerá-la uma previsão do comportamento do fenômeno estudado.

Todavia, quem está em um programa denominado Estudos Culturais, inevitavelmente trilha por diversos caminhos, caminhos estes que me levaram apenas tangencialmente à confirmação da minha hipótese. Tangencialmente porque descobri ao longo deste percurso que, ainda que a imposição de um regime temporal homogêneo das instituições para idosos possa causar impacto negativo sobre os ritmos biológicos dos residentes, há muitos outros aspectos desafiadores para ali viver-se a etapa final da vida 


\section{Limitações do estudo}

Desbravar a área biológica nos Estudos Culturais representou uma limitação, como soe acontecer em qualquer processo de desbravamento, entretanto, trouxe também um leque de possibilidades de ampliação do conhecimento e a constatação de que não existem muros delimitando as áreas, apesar de uma inquietação constante sobre o como ultrapassar esses limites sem perder de vista o nosso objeto de estudo.

Em relação à pesquisa de campo, uma limitação importante que enfrentei foi a perda de contato com a pessoa que me facilitou a entrada e a permanência na instituição onde fiz a maior parte do trabalho, em função de sua demissão do local. A partir de então tive dificuldades de transitar e de aplicar o protocolo de pesquisa junto aos profissionais, o qual era composto de várias questões e de uma entrevista gravada, o que seria muito mais rico para este trabalho, visto que as questões temporais e a rigidez de rotinas afetam os funcionários e podem causar problemas de saúde. Ao buscar os dados com os funcionários houve certa resistência por parte da administração, dando como justificativa que os mesmos estavam resistentes por suspeitarem que a pesquisa poderia voltar-se contra eles mesmos, porém, senti que havia alguma insegurança da administração em relação aos depoimentos que poderiam ser prestados.

Minha percepção é que, entre o tempo que decorre desde os primeiros contatos, a aprovação pelo comitê de ética e o desenvolvimento da pesquisa propriamente dita, podem ocorrer mudanças no quadro funcional e mesmo no otimismo gerado inicialmente pela expectativa de rápidos resultados do trabalho. 


\section{Conclusões}

Os dados coletados e as observações me permitiram concluir que viver em uma instituição de longa permanência não representa a continuidade da vida no domicílio, nem sua substituição. As regras temporais nas instituições não observam qualquer individualidade ou preferência, focando-se apenas nos cuidados. Os residentes não têm críticas sobre a rotina e horários e não proporiam mudanças; a maioria apresentou tendência à distimia e à depressão maior; mesmo os residentes que têm preferências vespertinas dormem cedo; a maioria relatou não ter apetite; apenas $10 \%$ residem por escolha própria. Se os residentes pudessem interferir nas regras temporais, quando possível, buscando considerar suas preferências individuais, isto influenciaria de maneira positiva, principalmente na qualidade do seu sono e no apetite, o que refletiria do seu estado de humor e colaboraria para a preservação de sua cognição, visto que inclusive por meio das análises estatísticas, a desorganização temporal entre os idosos foi parcialmente comprovada. Porém, a ação isolada de observar as regras e buscar adaptações para considerar preferências pessoais não mudaria de maneira efetiva a vida dos residentes nas instituições asilares. A intepretação dos discursos em busca do sentido do que é viver nesses locais foi o diferencial para ampliar os achados neste trabalho. Isso me permitiu inferir que o viver bem nas instituições estudadas, dentre outras mudanças, pressupõe que a instituição seja mais facilitadora na formação de uma rede social local e menos um agrupamento de indivíduos; que o velho se sinta mais pessoa e menos corpo a ser cuidado; que haja mais solidariedade e menos piedade. Dessa forma o cenário estará propício para considerar as preferências pessoais e minimizar os desafios temporais. 


\section{Considerações finais}

Acredito ser importante colocar uma breve explicação do porquê da abertura desse trabalho a poesia "Retrato" de Cecília Meireles que traz uma visão muito amarga e triste de um ser que não se reconhece no espelho. Esta descrição vai ao encontro do que Simone de Beauvoir (1990) declarou que ao ficar velha, tornou-se outra pessoa sendo ela mesma. $\mathrm{O}$ que observei na maioria das pessoas que fizeram parte da minha pesquisa é que, mesmo quando seu discurso era otimista, sua expressão e atitude eram condizentes com a pergunta de Cecília Meireles ao encerrar sua poesia: "em que espelho ficou perdido a minha face?". Esta pergunta enseja que pensemos no sentido da vida, não só dos que vivem em instituições, mas também em como dar sentido à nossa própria vida.

Penso que o fato de as pessoas que trabalham nas instituições chamarem os residentes de pacientes e estes chamarem todas as profissionais de enfermeiras denota o caráter hospitalocêntrico que tem sido observado nessas instituições asilares. Os modelos de instituições baseadas na filantropia parecem ter deixado herança no sentido de prestação de cuidados, muito mais como uma obrigação e um favor do que baseado no cuidado do outro, o que reforça o caráter de uma hospitalização por tempo indeterminado. Por outro lado, ultimamente temos observado uma tendência do estabelecimento em nosso país de empresas multinacionais que se especializaram em instituições para idosos, cujas mensalidades são bastante elevadas e que em geral eles utilizam outro vocabulário para se diferenciarem do modelo hospitalar. Nelas, o idoso é chamado de hóspede, o profissional, colaborador, a equipe, multiprofissional. À entrada existe uma recepção com ramais telefônicos, há uniformes para cada nível de prestador de serviço e o pessoal é treinado para atender os hóspedes e seus familiares de maneira muito profissional. Minha critica é que acabamos entrando aí em outro modelo que podemos denominar de hotelocêntrico e fica a dúvida de como será o sentido de pertencimento da pessoa ao deixar de ser um paciente para ser um hóspede e ali viver de maneira permanente.

Convém ressaltar aqui que atualmente é do meu conhecimento de que já existem diversas instituições asilares com uma visão mais holística do que é viver nesses locais, algumas das que conheço são gerenciadas por pessoas oriundas da gerontologia e que oferecem aos residentes atendimento das condições de higiene, alimentação e 
segurança, segundo a legislação, mas além disto, promovem atividades integrativas, respeitando os limites de cada residentes, as suas habilidades e o seu direito de escolha. Nesses locais seus espaços são personalizados com fotos e lembranças que lhes são caras, os profissionais conhecem todos pelo nome e procuram que entre os residentes eles se conheçam e se chamem pelos nomes. Não tenho conhecimento se os aspectos cronobiológicos, ou seja, os ritmos diários dos residentes são analisados e alguma adaptação é feita, mas sei que há flexibilidade nas rotinas para atender preferência por horários de dormir e levantar. São bons indícios de que estamos caminhando para melhorar a vida de quem vive nesses novos modelos de instituições asilares.

Minha área de base de estudos é a gerontologia, mas tenho sempre em vista as críticas antropológicas de como nós gerontólogos, bem como outros profissionais, temos a tendência de apontar soluções para a vida dos idosos e insistir no discurso de que se as pessoas não fizerem as coisas corretas ao longo da vida, elas não terão um envelhecimento bem sucedido, ou seja, serão derrotadas. Por isto me preocupa muito em como trabalhar as questões de envelhecimento e velhice, sem dar receitas generalizadas e acabar nos tornando prescritores, mesmo que não possamos prescrever especificamente fármacos, estaremos prescrevendo modos de viver. Encontrei em Groisman (2002) interessante análise sobre um grande desafio de quem trabalha com a velhice tentar sair do chamado binômio saúde-doença. Para isto, segundo sua observação, a prevenção foi uma saída encontrada pela gerontologia, tendo em vista que não existe uma definição única para quando começa a velhice, então todas as pessoas são potenciais alvos de receitas de prevenção em qualquer idade. E, segundo Groisman (2002) criar estes modelos pode se caracterizar como a ambição de disciplinar a vida humana em toda a sua extensão, em busca de um envelhecimento bem sucedido. Apesar de parecer que atualmente essa forma prescritiva tem estado em menor evidência, ela ainda representa um pensamento corrente.

De qualquer forma, a gerontologia tem a missão de preencher a lacuna deixada pela medicina que criou diversos meios que nos ajudaram a "ludibriar a morte", mas deixou como herança a velhice medicalizada, continuando como sinônimo de doenças e perdas.

Caso haja interesse e receptividade por parte das instituições nas quais desenvolvi esta pesquisa pretendo descrever possíveis formas para buscar uma maior 
flexibilidade na rotina local, buscando respeitar os ritmos biológicos dos residentes dentro dos tempos sociais da instituição, ou seja vamos chamar essa junção dos conceitos de temporalidades como tempo biossocial. Conforme já descrito no decorrer deste trabalho, o estabelecimento de regras temporais para os indivíduos indistintamente pode causar atritos que em longo prazo se cronificam e geram problemas de saúde. Por meio da cronobiologia nós poderemos descrever algumas possíveis ações para permitir considerar as preferências dos residentes, ajudando assim a afirmar suas identidades como pessoas. Dentre estas possibilidades de flexibilização das regras acredito que o primeiro ponto a ser considerado é que as próprias pessoas conheçam seus ritmos e a partir desse conhecimento possam negociar para melhor se adaptarem. Quando me refiro às pessoas, incluo aí tanto os residentes, quanto os profissionais que ali trabalham, visto que eles também são afetados pelo ritmo e os horários dos plantões. Convém observar que o termo "negociação" não significa a pretensão de sugerir o estabelecimento de uma rotina para cada pessoa, mas sim sugerir que a partir do conhecimento de suas temporalidades específicas os mesmos possam ter autonomia para propor alguma flexibilização que os tornem menos sujeitos e mais atores participantes de uma coletividade.

Retomando um autor citado anteriormente, o antropólogo Kevin Birth (1999), o qual defende que as críticas que precisamos fazer sobre a incompatibilidade entre tempos biológicos e demandas sociais deve idealmente gerar interesse para além das fronteiras disciplinares e que o conhecimento cronobiológico tem um grande potencial para contribuir para a crítica social. Ainda que Birth esteja se referindo a questões mais universais trazidas com a globalização, concordamos com o sentido da sua interpretação.

Para finalizar, cito novamente uma definição já colocada no percurso teórico deste trabalho relacionada ao termo isolamento asilar, onde comparei a vida de um residente na instituição com a de uma pessoa que vive no exílio, no aspecto de encontrar-se ali por razões alheias à sua vontade. Paulo Freire (2008) denomina essa cotidianidade estranha de "realidade de empréstimo". Freire diz que, não sendo aquele o seu lugar, e você tendo que lidar com sentimentos, recordações e visão do mundo acumulada, é como se vivesse uma realidade de empréstimo. Acredito que essa cotidianidade estranha da vida no exílio não precisa e nem deve ser reproduzida na 
instituição asilar, por isto, utilizo-me ainda das palavras de Paulo Freire (2008) quando diz que o ser humano deve entender a realidade como modificável e a si mesmo como capaz de modificá-la.

Assim, espero poder entender todas estas questões e pessoas aqui estudadas, tentando extrair desta experiência um aprendizado que servirá tanto para o meu próprio desenvolvimento, quanto para provocar alguma mudança positiva nos ambientes em que eu venha a atuar. 


\section{Referências bibliográficas}

ADAM, B. Timewatch: A análise social do tempo. Cambridge: Polity Press, 1995.

ALMEIDA O.P.; ALMEIDA S.A. Short versions of the geriatric depression scale: a study of their validity for the diagnosis of a major depressive episode according to ICD10 and DSM-IV. In: J Geriatr Psychiatry. v. 14, n. 10. p. 858-865, 1999.

ALTMAN, J. Observational Study of behavior: Sampling methods. Behaviour. v. 49, p. 227276, 1974.

ANDRADE, C.D. O Avesso das Coisas. Aforismos. Editora Record. 2 Ed. 1990.

ANDRADE, M.M.M. Ciclo vigília-sono de adolescentes: um estudo longitudinal. São Paulo, 1991. [Dissertação de Mestrado - Universidade de São Paulo].

Padrões temporais das expressões da sonolência em adolescentes. 166 f. Tese (Doutorado em Ciências: Fisiologia Humana) - Instituto de Ciências Biomédicas da Universidade de São Paulo, 1997.

ANDRADE, M.M.M; MENNA-BARRETO, L.; LOUZADA, F. Ontogênese da ritmicidade biológica. In: MARQUES, N.; MENNA-BARRETO, L. Cronobiologia: princípios e aplicações. 2. ed. São Paulo: Edusp/Fiocruz, 1999.

ARIÈS, P. História Social da Criança e da Família. Editora Guanabara, Rio de Janeiro, 1981.

BAPTISTA, M.M. Estudos Culturais: o quê e o como da investigação. Carnets, Cultures littéraires. Nouvelles Performance et dévellopment no.special, automne / hiver 2009, p. 451-461.

BARBIERI, N.A. O dom e a técnica: O cuidado a velhos asilados. Dissertação de Mestrado. São Paulo: Universidade Federal de São Paulo, 2006.

BARKER, C. Cultural Studies - Theory and Practice. Los Angeles/London: Sage, 3rd, 2008 .

BEAUVOIR, S. A Velhice. Tradução de Maria Helena Franco Monteiro. 5 ed. Rio de Janeiro: Nova Fronteira, 1990.

BENEDITO-SILVA AA, MENNA-BARRETO L, MARQUES N, TENREIRO S. Selfassessment questionnaire for the determination of morningness-eveningness types in Brazil. Prog Clin Biol Res. 1990;314:89-98.

BIRTH, K. Qualquer tempo é tempo Trinidad. Gainesville: University Press of 
Florida, 1999.

BLAIKIE, A. Ageing and popular culture. Cambridge:Cambridge University Press, 1999.

BOURDIEU, P. A 'juventude' é apenas uma palavra. In. BOURDIE, P. Questões de Sociologia, Marco Zero, Rio de Janeiro, 1983.

BRAGA, A.M. O tempo de trabalho e os demais tempos sociais das mães que costuram calçados em Franca. Franca: UNESP, 2008.

BRASIL. Ministério da Previdência e Assistência Social. Secretaria de Políticas de Assistência Social. Portaria no. 73. Normas de funcionamento de serviços de atenção ao idoso no Brasil, 2001.

BRASIL. Ministério da Saúde. Estatuto do Idoso / Ministério da Saúde. 1 ed, 2a reimpr. Brasília: Ministério da Saúde, 2003.

BRASIL. Ministério da Saúde. Secretaria-Executiva. Núcleo Técnico da Política Nacional de Humanização. HumanizaSUS: Ambiência / Ministério da Saúde, Secretaria-Executiva, Núcleo Técnico da Política Nacional de Humanização. - Brasília: Ministério da Saúde, 2004.

BRASIL. Agência Nacional de Vigilância Sanitária (ANVISA). Resolução da Diretoria Colegiada $\mathrm{N}^{\circ} 283$, de 26 de setembro de 2005. Regulamento técnico para o funcionamento das instituições de longa permanência para idosos. Brasília: ANVISA; 2005. Disponível em: < http://websphere.anvisa.gov.br/wps/wcm/connect/ae5d4580430d5cc6a5ceb7536d6308d b/RDC+N\%C2\%BA+283-2005.pdf?MOD=AJPERES $>$

BRASIL. Instituto Brasileiro de Geografia e Estatísticas (IBGE). PNAD - Pesquisa Nacional por Amostra de Domicílios, 2011. Disponível em: http://www.ibge.gov.br/estadosat/temas.php?sigla=sp\&tema=censodemog2010_amostra Acesso em: 30-05-2016.

BRETON, D.L. Adeus ao corpo. Campinas: Papirus, 2011.

CAMARANO, A.A.; Kanso, S. As instituições de longa permanência para idosos no Brasil. Revista Bras. Est. Pop., Rio de Janeiro, v. 27, n. 1, p. 233-235, jan./jun. 2010. CAMARANO, A.A. Envelhecimento da população brasileira: continuação de uma tendência. Revista Coletiva, Recife, número 05, jul-ago-set/ 2011.

CANGUILHEM, G. O normal e o patológico. Rio e Janeiro: Forense Universitária, 
1978.

CAPONI, S. Da compaixão à solidariedade: uma genealogia da assistência médica. Rio de Janeiro: Fiocruz, 2000.

CEOLIM, M. F. Padrão de atividade e de fragmentação do sono em pessoas idosas. Tese (Doutorado em Enfermagem) - Universidade de São Paulo, São Paulo, 1999.

CERTEAU, M. A invenção do Cotidiano. Petrópolis: Vozes, 1998.

CLOS, M. Recusa, Conformidade e Libertação: considerações sobre o processo de adaptação de idosos em uma Instituição de Longa Permanência para Idosos. Dissertação de Mestrado. Faculdade de Educação da Unversidade Federal do Rio Grande do Sul. Porto Alegre, 2010.

CORREIA, M.C.B. A Observação Participante Enquanto Técnica de Investigação. Rev. Pensar Enfermagem. Lisboa, v.13, n. 2, 2009.

COUTO, M.C.P.P. Avaliação de Discriminação contra Idosos em Contexto Brasileiro - Ageismo. Rev. Psicologia: Teoria e Pesquisa, v. 25, n. 4, 2009.

DALGALARRONDO, P. Conceito de normalidade em psicopatologia. In. DALGALARRONDO, P. Psicopatologia e semiologia dos transtornos mentais. Porto Alegre: Artes Médicas, 2000.

DEBERT, G.G. Pressupostos da Reflexão Antropológica sobre a Velhice. In Antropologia e Velhice, Textos Didáticos. SP: IFCH/ UNICAMP. 1994 A reinvenção da Velhice: socialização e rocesso de reprivatização do envelhecimento. São Paulo: FAPESP, 1999. A Antropologia e o Estudo dos Grupos e Categorias de Idade. In: BARROS, M.M.L. (org.) Velhice ou Terceira Idade? 3 ed. Rio de Janeiro: Fundação Getúlio Vargas Editora, 2003. Ainda não existem instituições que tragam dignidade à velhice.

Entrevista para o jornal Folha de São Paulo em 24-01-2012. Disponível em: http://www1.folha.uol.com.br/treinamento/mais50/ult10384u1017406.shtml. Acesso em: 07-02-2016.

DUARTE, M.J.R.S. Atenção ao idoso: um problema de saúde pública na enfermagem. Rev Enferm UERJ, 2004. 
DURKHEIM, E. O que é fato social? In: As Regras do Método Sociológico. Trad. por Maria Isaura Pereira de Queiroz. 6 ed. São Paulo: Companhia Editora Nacional, 1972

ELIAS, N. Tempo: Um ensaio. Oxford: Blackwell, 1992.

Sobre o tempo. Rio de Janeiro: Jorge Zahar, 1993.

A Solidão dos Moribundos. Rio de Janeiro: Jorge Zahar Editor, 2001.

ESCOSTEGUY, A.C. Os Estudos Culturais. Disponível em: http://www.pucrs.br/famecos/pos/cartografias. Acesso em: 10-set-2015.

ESPITIA, A. Z.; MARTINS, J.J. Relações afetivas entre idosos institucionalizados e família: encontros e desencontros. Arquivos Catarinenses de Medicina, vol. 35, n. 1, 2006. Disponível em http://www.acm.org.br/revista/pdf/artigos/355.pdf. Acesso em 1305-2016.

FODDY, B. The Right and Wrong of Growing old: Assessing the Argument from Evolution. Philosophy \& Technology. Online publishing. 28-Feb-2012.

FOUCAULT, M. História da Sexualidade I: a vontade do saber. Rio de Janeiro: Graal, 1985.

A Ordem do Discurso - Aula inaugural no Collège de France. Pronunciada em 2 de dezembro de 1970. São Paulo: Ed. Loyola, 1996.

Vigiar e Punir Nascimento da Prisão. Petrópolis: Editora Vozes, 29 ed., 2004.

FREIRE, P. Pedagogia da Esperança: um reencontro com a Pedagogia do Oprimido. 15 ed. Rio de Janeiro: Paz e Terra, 2008.

GEIB, L.T.C. et al. Sono e envelhecimento. Rev. Psiquiatr. RS, v. 25, n. 3, p. 453465, 2003.

GOFFMAN, E. Estigma Notas sobre a Manipulação da Identidade Deteriorada. 4. ed. Rio de Janeiro: LTC, 1963.

Manicômios, Conventos e Prisões. 4. ed. Rio de Janeiro: Perspectiva, 1974.

GORDON, A.L.; GLADMAN, J.R.F. Sleep in care homes. Reviews in clinical Gerontology. v. 20, n. 4. p. 309-316, 2010.

GOUVÊA, M.A.C. Terceira idade, ainda tempo de semear. Petrópolis: Vozes, 2002.

GRAEFF, L. O mundo da velhice e a cultura asilar: estudo antropológico sobre memória social e cotidiano de velhos no Asilo Cacique em Porto Alegre. Dissertação de 
Mestrado em Antropologia Social - Instituto de Filosofia e Ciências Humanas, UFRGS. Porto Alegre, 2005.

GROISMAN, D. A infância do asilo: a institucionalização da velhice no Rio de Janeiro da virada do século. Dissertação de Mestrado. Rio de Janeiro: Universidade do Estado do Rio de Janeiro, 1999.

A velhice entre o normal e o patológico. História da Ciência e da Saúde - Manguinhos Rio de Janeiro: v.9, n. 1, p 61-78, jan-abr 2002.

HARMAN, D. Free radical theory of aging: an update: increasing the functional life span. Annals of the New York Academy of Sciences, v. 1067, p. 10-21, 2006.

HORNE J.A.; ÖSTEBERG, O.F. A self-assessment questionnaire to determine morningness-eveningness in human circadian rhythms. Inter. J. Chronobiol, v. 4, n. 2, p. 97-110, 1976.

LAPOINT, J. When a theory of aging ages badly. Cellular and Molecular Life, 2010.

Lee, C. Gene expression profile of aging and its retardation by caloric restriction. Science. New York, NY, v. 285, n. 5432, p. 1390-1393, 1999.

LASLETT, P. A fresh Map of Life: The Emergency of the Third Age. Cambridge: Harvard University Press, 1989.

LYNCH, M. D. The role of cellular senescence may be to prevent proliferation of neighboring cells within stem cell niches. Ann NY Acad Sci, v. 1019, p. 191-194, 2004.

MAC RAE, P.G.; SCHNELlE, J.F.; SIMMONS, S.F. et al. Physical activity level of ambulatory nursing home reisidents. Journal of Aging and Physical Activity, v. 4, n. 3, p. 264-278, 1996.

MALINOVSKI, B. Argonautas do Pacífico Ocidental. São Paulo: Abril Cultural. 2 Ed., 1978 [1922].

MANSANO-SCHLOSSER, T.C.; SANTOS, A.A.; CAMARGO-ROSSIGNOLOL, S.O.; FREITAS, D.C.C.V.; LORENZ, V.R.; CEOLIM, M.F. Idosos institucionalizados: organização cronológica das rotinas diárias e qualidade do sono. Rev. Bras. Enferm., v. 67, n. 4, p. 610-6, 2014.

MARQUES, N.; MENNA-BARRETO, L. Cronobiologia: Princípios e Aplicações. 3ed. rev. e ampl. São Paulo: Editora da Universidade de São Paulo, 2003.

MASORO, E.J. Challenges of biological aging. Nova York, Springer Publishing 
Company, 1999.

MELUCCI, A. Um objetivo para os movimentos sociais? Rev. Lua Nova - São Paulo, n. 17 - June, 1989.

MENNA-BARRETO, L.; FORTUNATO, G.O. O que é cronobiologia? In: CIPOLLANETO, J.; MARQUES, N.; MENNA-BARRETO, L.S. (ed.) Introdução ao estudo da cronobiologia. São Paulo: Icone, 1998.

MENNA-BARRETO, L. Homeostasia: uma revisão necessária? Revista de Neurociências. Atlântida Editora - Secção Perspectivas, 1:105-107, Junho de 2004.

MENNA-BARRETO, L.; DÍEZ-NOGUERA, A. External temporal organization in biological rhythms. Biological Rhythm Research, p. 1-12, 2011.

NERI, A. L. Envelhecimento e qualidade de vida na mulher. In: Congresso Paulista de Geriatria e Gerontologia, 2., 2001, São Paulo. Anais. São Paulo: GERP, 2001. p. 0118. Disponível em: http://www.portaldoenvelhecimento.org.br/artigos/maio2007/2congresso.pdf. Acesso em: 20/11/15.

NERI, A. L. (org.). Idosos no Brasil: vivência, desafios e expectativas na terceira idade. São Paulo: Editora Fundação Perseu Abramo, 2007.

NERI, A.L.; Freitas, E.V.; Py, L. et al. Tratado de Geriatria e Gerontologia. 1 ed. Rio de Janeiro: Guanabara Koogan, 2002.

Oliva-AuguSto, M.H. Tempo, Indivíduo e Vida Social. Cienc. Cult. São Paulo, v. 54, n. 2, 2002.

OLSHANSKY, S. J.; HAYFLICK, L.; CARNES, B. A. Position statement on human aging. The Journals of Gerontology Series A. Biological Sciences and Medical. Sciences, v. 57, n. 8, p. B292-B297, 2002.

ORLANDI, E. P. Análise de discurso: princípios e procedimentos. Campinas, SP: Pontes, 1999.

PALMEIRA, M. Política e Tempo: nota exploratória. In. PEIRANO, M. O dito e o feito. Rio de Janeiro: Relume Jumará, 2001.

PAULIUKONIS, M.A.L. Processos de discursivização: da língua ao discurso caracterizações genéricas e específicas do texto argumentativo. Veredas, revista de estudos lingüísticos Juiz de Fora, v. 4, n. 2 p. 89 a 96, Jul./Dez. 2000.

PAWELEC, G. Human immunosenescence: does it have an infectious component. 
Annals of the New York Academy of Sciences, v. 1067, n. 1, p. 56-65, 2006.

PÊCHEUX, Michel. O Discurso: Estrutura ou acontecimento. Tradução Eni Orlandi. 3. ed. Campinas, SP: Pontes, 2002.

PEDREIRA, C.A.M. O que é contracultura. São Paulo: Nova cultural/Brasiliense, 1986.

PEIXOTO, C. Aposentadoria: retorno ao trabalho e solidariedade familiar. In: PEIXOTO, C.(orgs.). Família e Envelhecimento. Rio de Janeiro, FGV, 2004.

PESTANA, L.C.; ESPÍRITO-SANTO, F.H. As engrenagens da saúde na terceira idade: um estudo com idosos asilados. Rev. Esc. Enferm. USP, São Paulo, v. 42, n. 2, June, 2008.

RAMOS, L.R.; VERAS, R.P.; KALACHE, A. Envelhecimento populacional: uma realidade brasileira. Rev. Saúde Pública. v.21, n. 3, p. 211-24, 1987.

REINBERG, A. Des rythmes biologiques à la cronobiologie. Paris: Gauthier-Villars, 1977.

RICHARDSON, R.J. Pesquisa Social: Métodos e Técnicas. 3 ed. São Paulo: Atlas, 1999.

ROBERTSON, A. The politics of Alzheimer's disease: a case study in apocalyptic demography. J. Heath Serv. 1990:20(3):429-42.

ROCHA, A.L.; ECKERT, C. A memória como espaço do fantástico. Porto Alegre: Banco de Imagens e efeitos visuais, 2000. ROENNEBERG, T.; KUEHNLE,T.; PRAMSTALLER P. P.; RICKEN, J.; HAVEL , M.; GUTH, A.; MERROW, M. A marker for the end of adolescence. Current Biology, Vol.14, Issue 24, Pages R1038-R1039, 2004.

ROLANT, M.T. Trabalhar menos e viver melhor. In: GORZ, A. Adeus ao proletariado: para além do socialismo. Rio de Janeiro: Forense Universitária, 1987.

RUSSELL, B. Elogio ao Ócio. Rio de Janeiro: Sextante, 2002 [1935].

SAMIS, H.V. Aging: the loss of temporal organization. Perspectiva Biológica, v. 12, n.1, p. 85-102, 1968.

SANTOS, N.C.; MENEGHIN, P. Concepções dos alunos de graduação em enfermagem sobre o envelhecimento. Rev Esc Enferm USP, v. 40, n. 2, p. 151-9, 2006. 
SHEIKH, J.I.; YESAVAGE, J.A. Geriatric depression scale (GDS): recent evidence and development of a shorter version. Clin Geronto, v. 5, p. 165-173. 1986.

THOMPSON, E.P. Tempo, disciplina de trabalho e capitalismo industrial. In. Costumes em comum. Estudos sobre a cultura popular tradicional. São Paulo: Companhia das Letras, 2005.

TOMASINI, S.L.V.; ALVES, S. Envelhecimento bem-sucedido e o ambiente das instituições de longa permanência. RBCEH, Passo Fundo, v. 4, n. 1, p. 88-102, jan./jun.2007. Disponível em:

http://www.upf.tche.br/seer/index.php/rbceh/article/viewFile/119/94. Acesso em: 3105-2016.

VALADARES, N.D.C. Distúrbios de Sono no Idoso. In: CANÇADO, F.A.X. Noções Práticas de Geriatria. Belo Horizonte: Coopmed Editora, p. 234-240, 1994.

VAN SOMEREN, E.J. Circadian and sleep disturbances in the elderly. Exp.Gerontol. v. 35, n. 9-10, p. 1229-37, 2000.

VAUPEL, J. W. Biodemography of human ageing. Nature, v. 464, n. 7288, p. 536-542, 2010.

VEIGA-NETO, A. Michel Foucault e os Estudos Culturais in Estudos Culturais em Educação. Porto Alegre: Editora da UFRGS, 2000.

VELHO, G. Observando o familiar. In: Individualismo e Cultura: notas para uma antropologia da sociedade contemporânea. Rio de Janeiro: Zahar, 8 ed, 2008.

VERAS, R.P. A vida mais longa no mundo: determinantes demográficos. In: VERAS, R. P. País de jovem com cabelos brancos: a saúde do idoso no Brasil. Rio de Janeiro: Relume Dumará, 1994.

VERAS, R.P. Terceira idade: gestão contemporânea em saúde. Rio de Janeiro: UNATI, 2002.

VOYER, P.; VERREAUlT, R.; MENGUE, P.N.; MORIN, C.M.; Prevalence of insomnia and its associated factors in elderly long-term care residents. Arch Gerontol Geriatr., v. 42, n. 1, p.1-20, 2006.

WEBB, W. B.; BONETT, M. H. The sleep of 'morning' and 'evening' types. Biol. Psychol. v. 71, p. 29-35, 1978. 
YESAVAGE, J.A.; BRINK ,T.L.; ROSE T.L.; LUM, O.; HUANG,V.; ADEY, M. et al. Development and validation of a geriatric depression screening scale: a preliminary report. J. Psychiat Res. v.17, n. 1, p. 37-49, 1983. 


\section{APÊNDICES}

\section{A - Relatos de Observação Selvagem}

Parte integrante da pesquisa sobre Rotinas em Instituições para Idosos

Relatos de Observação Selvagem - 2014

Local de observação: Instituição para Idosos na Zona leste da cidade de São Paulo

Pesquisadora: Evany Bettine de Almeida

Orientador: Luiz Menna-Barreto

Horas totais de observação: 11 horas

Pessoas observadas: 77

Rotinas observadas: todas exceto café da manhã, pois as entradas externas são permitidas a partir das 10 horas.

Sigilo: os nomes referenciados nos relatos são fictícios

As visitas para observação

$1^{\text {a }}$. visita - Unidade 4 - Dia 24/07/2014 - $5^{\text {a }}$.feira - cheguei às 16:00h

Fui recebida pela atendente que me mostrou a casa e explicou os casos que eles atendem. Conheci Lais, uma residente que perdeu a audição e perdeu o antebraço num incêndio e entrou recentemente num processo de demência de Alzheimer. Ela estava dormindo no sofá, apesar de ser um momento de as pessoas estarem acordadas. Conheci também Manu que sofreu um AVC e está muito debilitada, não consegue deglutir. O filho veio visitá-la e disse que vai contratar uma fonoaudióloga para ensiná-la a comer. Mesmo com a presença dele ela continuou passiva, olhando para o nada, bem triste. Elisa é outra residente. Ela é bem lúcida, está sentada, pernas esticadas, assiste TV com interesse. Ela explicou para uma das auxiliares como ela quer que arrume sua cama, disse que tem alergia a cobertor e explicou como tem que fazer a dobra do seu lençol. Começou uma novela e o interesse dela aumentou. Chegou na sala o Hiro, um japonês, que é único homem da casa. Ele sofreu um AVC, mas ele mesmo fica se exercitando para recuperar os movimentos; ele é muito esforçado e disse que não precisa de uma fisioterapeuta, disse que vai se recuperar sozinho. Ele veio para a casa por escolha própria, ele é muito simpático e otimista. A sala de estar é ampla e clara, cerca de $6 \mathrm{~m} \mathrm{x}$ $4 \mathrm{~m}, 14$ poltronas e sofás em couro preto, uma TV, plantas e piso de tacos de cor marfim. O quintal é relativamente grande, tem cobertura e possui barras de mão nas laterais e mesas para refeições externas.

Quando cheguei eles haviam tomado o café da tarde. Agora já se aproxima a hora do jantar; passa um pouco das $17 \mathrm{~h}$. Isa, a pessoa que me atendeu se despede de 
mim e das auxiliares de forma bem simpática. Perguntei a ela o que a atraía para, tão jovem, se dedicar a este tipo de trabalho, pois ela me disse que trabalhava com idosos desde os 17 anos. Aí descobri que ela é filha da dona da instituição.

As auxiliares começam a trazer o jantar, uma sopa de legumes que tem um cheiro muito bom. Elisa come sozinha; Lia precisa ser alimentada. A cuidadora que dá comida para Lia não presta muita atenção no que faz, não interage com ela. Na sala tem uma campainha que toca quando algum residente que está nos quartos precisa de uma auxiliar. Elisa termina de comer, devolve a travessa de sopa. A Auxiliar traz um medicamento, ela toma sem perguntar o que é. O som da TV é bem baixo e as telas têm legendas. Por um tempo ninguém mais entra na sala, ninguém conversa. Chegou a sopa da Manu, vem batida no liquidificador, pois ela não consegue mastigar. Lia cochila novamente após comer. A mesma cuidadora que deu comida para Lia vai dar para Manu; ela esfria a sopa enquanto olha a TV. Chegou outra auxiliar dizendo que achou um remédio que tinha esquecido no bolso; era um pozinho branco para colocar na sopa da Manu. Entra outra auxiliar e comenta que uma residente chamada Abigail não quer comer e se recusa a tomar o remédio; outra colega vai para dentro ver o caso. Manu vai comendo sem que a cuidadora fale com ela; ela comeu tudo e tomou suco de laranja. Ninguém se fala, só há 3 mulheres... e a TV na sala. Há uma residente chamada Maria que passa pela sala muitas vezes e fica falando sozinha, segue em frente, daí a pouco entra pelo outro lado. Ela veio falar comigo, me pediu desculpas por não estar me dando atenção, pois está com um problema: a mãe dela morreu e ela tem que ir para Cambuquira em Minas, onde as irmãs já estão. Pergunta para todos na sala se alguém ligou para ela; pega o telefone, que não tem linha, disca uns números e diz que ninguém atende. Entra Sueli, amiga de Maria. As duas falam sobre o velório mas agora dizem que está sendo realizado ali mesmo, na casa ao lado, mas ninguém atende o telefone, pois estão ocupados com o velório. Sueli e Maria vão para dentro para colocarem casacos para irem ao velório. Afinal, diz Sueli, "quando a mãe da gente morre não podemos deixar de ir ao velório e eu vou com você". Percebi que ela dizia isto, acreditando e entrando de fato na história da amiga. Lia dorme novamente; só Elisa assiste TV. A cuidadora leva Lia para trocar a fralda; o local onde Lia estava fica com o forro encharcado de xixi, mas a sala não tem cheiro de urina. Começa outra novela, Elisa assiste. Manu continua na sala, sem expressão. Somente as duas ficam lá; sem 
auxiliares e demais residentes. Nesta casa há alguns quartos individuais, por exemplo, o Hiro fica em seu quarto muito tempo e há outro residente, que não apareceu na sala, mas que eu conheci quando fiz a primeira visita junto com a proprietária. Ambos têm seus quartos com seus pertences e computadores. A sala continua quase vazia, a campainha toca chamado de algum quarto; as duas que iriam ao velório não voltam mais para a sala.

Saí de lá às 18 horas.

\section{Anotação feita num momento posterior:}

Esta visita, por ter siso a primeira, representou para mim uma experiência entediante. Saí de lá com vontade de comer uma refeição bem pesada e beber algo, buscando amenizar o efeito da visita. Mas, após conhecer outros residentes e realidades nas unidades seguintes, percebi que o ambiente na Unidade 4 é o mais tranquilo e leve dentre todas.

$2^{\text {a }}$. visita - Unidade 3 - Dia 29/07/2014 - 3 $3^{\text {a }}$ feira - cheguei às 17h:50min

A auxiliar de enfermagem Jô me deixou entrar somente com minha explicação da intenção da observação dos residentes. Jô disse para eu me sentar onde preferisse e ficar à vontade. Em seguida uma atendente chamada Regina fez questão de me mostrar todas as dependências da casa, inclusive mostrando as pessoas que se encontram acamadas. Ela me explicou que a princípio eles não recebem pessoas já acamadas, mas uma vez residentes, se adoecerem e precisarem de cuidados eles podem continuar na instituição, havendo uma residente, por exemplo, que está em estado vegetativo.

Fui para a sala de estar para iniciar as observações.

Havia 8 pessoas, sendo 6 mulheres e 2 homens, TV ligada, som alto, uma mulher assistindo. Uma atendente veio buscar uma residente para jantar na mesa; outra mulher ficou reclamando sem parar, dizendo que era muito cedo para jantar, mas ninguém deu atenção. Uma mulher ficava andando pela sala e queria sair para a rua; ela dizia que queria ir para casa e que era para abrir pra ela. Em seguida mudou um pouco a dinâmica, pois chegou a filha de um homem para visitá-lo - lá as visitas são livres, desde que o residente esteja acordado as visitas podem permanecer com eles. A moça veio trazer coisas de comer para o pai, pois ele come muito pouco lá, então ela trouxe danone, bolachas, manteiga, café com leite em pó, coisas que ele gosta. As atendentes guardam as coisas com o nome do residente. A filha tentou dar a janta na boca dele, mas 
ele não abre a boca de jeito nenhum e fica falando sem parar, coisas sem nexo, dizendo que tinha acabado de chegar da cidade e que precisava voltar de novo daí a pouco. Aí a filha começou a dar o danone e ele comeu tudo. Um homem estava comendo sozinho, mas com dificuldade de "acertar" a boca, então a comida caía toda pelo canto da boca ficando tudo parado no rosto dele. A senhora que reclamava do horário recebeu o prato foi para a mesa, mas antes de comer começou a perguntar o que era aquilo, então a atendente falou para ela comer, senão a atendente iria colocar na boca dela e ela não gosta de ser ajudada. O homem que falava sem parar se chama Antonio e parece estar com a cognição bem comprometida. $\mathrm{O}$ homem que deixava a comida cair no rosto acabou de comer e limpou com a toalha toda a sopa que havia derrubado. Ele tem paralisia lateral, deve ter sofrido um AVE. Outra mulher comeu, mas reclamava o tempo todo que a sopa estava grossa. Duas delas estavam com muita tosse e com muita secreção, tossiam sem parar. A senhora que reclamou que era cedo para comer, voltou para a sala, se cobriu com um cobertor. É inverno, faz frio e garoa. Ela começou a prestar a atenção na TV, pois passava uma novela. Ela parecia estar cognitivamente bem. A atendente começou a falar para o Sr. Antonio e para a Glorinha (a que reclamava da comida) que se eles não comessem tudo, a médica iria levá-los para o hospital para tomar soro. Outro senhor que também parecia estar bem voltou para a sala após comer sozinho, cobriu-se com o cobertor e ficou observando os outros. Glorinha e ele começaram a conversar, mas não deu para ouvir por causa do som da TV. A mulher que ficava andando de um lado para o outro começou a reclamar dizendo que iria faltar no dia seguinte, pois precisava fazer queijo e nadar. Veio uma auxiliar trazendo os remédios de todos (a maioria toma medicamentos). Ela traz água na caneca plástica e todos tomam, alguns com muita dificuldade. O Sr. Antonio precisa tomar injeção, uma enfermeira aplicou. O homem que deve ter sofrido o AVE tem muita dificuldade de linguagem, ele gagueja muito, fala alto e não dá para entender o que ele fala. A sala é grande (cerca de $24 \mathrm{~m} 2$ ) e a TV se localiza em um dos cantos, de forma que somente umas 3 pessoas conseguem assistir, mas nem esta quantidade de pessoas estava prestando atenção na TV. A moça que fez o procedimento no senhor Antonio não era funcionária, mas sim uma pessoa do plano de saúde. A mulher que andava sem parar e queria ir embora, segurava sua bolsa junto ao peito e com as duas mãos. Uma hora ela cochilou, mas acordou em seguida, abraçou a bolsa e depois conferiu tudo o que estava 
dentro. O homem que gagueja e não consegue falar começou a falar coisas ininteligíveis e Glorinha (sentada ao lado dele) fica imitando a gagueira dele. Ele diz: qué, qué, quero - qué, qué, quero. Aí a mulher do lado começa: “qué,qué, qué, qué, qué, qué! desembucha aí o cara chato!" A outra que está sentada ao lado dele e que parece lúcida, reclama que ele fala muito alto e que a casa não é dele, "é nossa!", então cale a boca! Glorinha também começou a gritar e a mulher ao lado, disse pra ela calar a boca senão iria dar um tapão nela, mandou ela ir à merda e disse que estava querendo cochilar e eles não deixavam. A campainha da casa toca, ninguém para atender. Aí Irina vai até a porta ver quem é. A mulher que parecia lúcida disse: é meu filho Flávio, ele vem para dormir, pois saiu com uns amigos. Seu nome é Moraleia e ela disse que não sabe onde foram achar este nome horroroso. Ela que parecia lúcida, pelo jeito não é! A mulher que segura a bolsa junto ao corpo se chama Irina e fica choramingando e se lamentando sem parar, agora olhando para um pedaço de papel. A mulher que tosse muito se chama Iris, ela voltou da mesa onde jantou e já começou a cochilar. Aí as auxiliares vieram buscar o homem com AVE e o passaram para a cadeira de rodas para levá-lo pois ele queria dormir. Depois vieram buscar a Glorinha. Um senhor que consegue andar sozinho fica deambulando nos espaços o tempo todo e não olha e nem fala com ninguém. Nenhum olha a TV, cochilam ou olham para o nada. Três auxiliares vieram buscar uma senhora que não se movimenta nada e a levaram para dentro. Cada pessoa que é levada demora um bom tempo, pois elas trocam ou colocam fralda em todos para dormir. Mesmo os que não usam fralda durante o dia têm que colocar para evitar possíveis quedas, além de luz acesa e barulho. Aí os demais ficam esperando, esperando e começam a pedir para serem levados. Um tempo depois duas auxiliares vieram buscar uma que se chama Rosa. Como ela consegue andar, elas a levam pelas mãos bem devagar. Irina continua choramingando, o homem que anda sem rumo, continua andando. Às 18h30min os que ficaram na sala estão todos cochilando, menos Antonio que fala sem parar. Uma senhora chamada Lourdes e que parece lúcida, veio espontanemanete se sentar ao meu lado. Começou a contar que ficou sozinha no mundo. Os filhos disseram que querem que ela fique muito bem e ela faz de conta que está bem para eles não ficarem tristes, mas o coração dela fica "murchinho" quando eles vão embora. Começa um daqueles programas que só falam de crimes, mesmo assim só um homem olha. Seis na sala, ninguém presta atenção. Irina para de choramingar e cochila. Lourdes volta a dizer que 
é muito apegada aos filhos e que isto não é bom para eles, pois ela sabe que eles têm que ter suas próprias vidas, pensar no futuro.

Conversei com uma mulher chamada Iris, pois ela me chamou; ela parou de tossir. Ela parece bem lúcida. Disse que dorme com outras 4 mulheres. Ela disse que veio pra a casa, pois é lógico todo mundo trabalha e não pode "olhar a gente". Ela disse: "hoje minha filha veio me visitar, trouxe remédios. Eu pago meu convênio e pago esta clínica. Tenho um apartamento alugado aqui perto. Eu tinha uma cuidadeira, mas começou muita fofoca, precisaria ser uma pessoa de muita confiança, por isto eu não quis mais. Aqui estou bem e quero morrer aqui. Em 8 de agosto vou fazer 92 anos, eu sou de 1922. Eu tenho uma irmã que tem 97 anos ela mora na casa dela e tem uma cuidadeira, mas você vê, a mulher tomou conta de tudo... elas são assim mesmo...”.

Todos dormem, menos Iris, ela fica esperando que a venham buscar. Ao lado de Iris está Aparecida que acordou e começou a pedir para virem buscá-la. Ela queria que eu a levasse para o quarto. Perguntou meu nome, quando eu disse Eva, ela falou: "Eva, me leva pro paraíso agora". Aparecida disse que no quarto dela tem 7 camas, mas uma pessoa está no hospital. Ela disse que tem 93 anos, é de 21. Disse que levanta 5 vezes à noite e é a única que não usa fraldas, é um orgulho, pois é a mais velha de todas as unidades e não usa fraldas. Ela morava com a filha, mas como seria se acontecesse algo com ela à noite? A filha não poderia fazer nada, então ela foi colocada ali. Aquelas que ainda estão na sala ficam pedindo para irem pra cama, mas não tem auxiliar disponível.

Pelo que percebi, eles querem ir dormir muito cedo, a partir das dezoito e trinta, mas alguns acabam esperando muito tempo. Quando fui embora ainda havia três pessoas esperando as auxiliares.

Saí de lá às 20h.

$3^{\mathrm{a}}$. visita - Unidade $2-31 / 07 / 2014-5^{\text {a }}$.feira - cheguei às 17:00

Fui atendida por uma enfermeira chamada Élida. Ela também me deixou entrar e foi muito solícita. Havia 9 pessoas na sala, 6 mulheres, 3 homens. Horário de começarem a jantar, TV ligada na novela, som alto, ninguém olhando. A janta era sopa para aqueles que não comem sozinhos e macarrão para quem consegue comer sozinho. Um homem foi alimentado por uma auxiliar, mas nenhum olhava para o outro. Ele olhava para baixo e às vezes olhava para mim. Outro homem chamado Antonio ficava 
andando de um lado para ao outro, mexendo as mãos ao mesmo tempo; quando sentava ficava tamborilando com os dedos nas pernas, lambendo a colher de comida. Uma senhora com o corpo completamente largado no sofá e sem sapatos estava com olhar perdido no nada. Duas mulheres conversavam sobre a comida. Uma delas não enxergava, a outra conversava com ela, mas não deu para saber o que elas falavam por causa do som da TV. Era aniversário de 93 anos de uma residente, Etna, e sua sobrinha veio visitá-la para lhe dar a janta. A sobrinha é o único parente que Etna tem e ela vem a cada dois dias dar a janta para a tia. Havia 3 auxiliares circulando. A Élida me disse que este não era um bom horário para eu observar, pois eles jantavam e já queriam ir dormir. Ela falou para eu voltar num outro dia no horário do café da tarde, pois aí eles interagiam, faziam alguma atividade. A sobrinha de Etna me conta que a tia era lúcida até poucos anos. Até os 89 anos ela lia jornal todos os dias, não usava óculos, não tomava qualquer medicamento para hipertensão ou diabetes. Porém, morreu uma filha dela aos 53 anos e ela ficou completamente sem memória no mês seguinte. "Parece que ela se desligou do mundo...". Duas auxiliares vieram buscar a senhora que não se movimenta; ao levantarem a mulher, o local ficou todo molhado de xixi. Antonio que estava sentado ao lado ficou passando a mão no xixi, ao mesmo tempo batia os pés no chão.

As roupas deles são muito simples, até meio desarrumados. É inverno; muito frio; eles colocam blusas em cima de blusas, duas calças, cobertor. A mulher que não enxerga é descendente de orientais. Ela e sua vizinha ao lado, continuam conversando sem parar, a conversa é sem nexo, mas elas mantêm a conversação. Cada uma falando um assunto. Vieram buscar a japonesa para dormir; ela foi andando. Outra senhora foi levada de cadeira de rodas. A sobrinha da Etna conversa com ela coisas do dia-a-dia e a Etna responde outra coisa; ai a sobrinha pergunta algo sobre o que a tia falou e aí a tia responde uma terceira coisa. Uma auxiliar fala com uma mulher que está cochilando, fala como se ela fosse uma criança: "ai que judiação da minha belezinha, tá com soninho? Vou trazer a cobertinha". As auxiliares vêm buscar Etna para ir dormir, então a sobrinha dela conversa com uma senhora que estava ao lado, chamada Júlia. Só que Júlia também não dizia nada com nexo, mas a sobrinha mantinha a conversa a partir das palavras de Júlia.

Cheiro de xixi; ninguém olha a TV, restam os três homens na sala. Uma auxiliar 
chama um senhor, o Otavio para ir dormir. Ele diz que não quer e que vai ficar na sala. Elas dizem que só irão trocá-lo e que depois ele pode ficar na sala quantas horas ele quiser. Mas ele se recusa e fica bravo. Aí Élida manda as auxiliares fazerem outra coisa; quando elas saem Otavio diz que quer ir para dentro. Élida disse que agora ele tem que esperar, pois elas foram fazer outra coisa e ele fica furioso. Daí a pouco elas voltam e o levam. Após trocar a fralda ele diz que quer ficar lá mesmo e não volta mais para a sala. Eles dormem por volta da 18h30min e levantam às 7h30min. Ou seja, ficam 13 horas na cama.

Élida conversa muito comigo espontaneamente. Conta que estudou enfermagem no Mato Grosso de onde ela é; lá na cidade dela existem muitos grupos indígenas e também há muitos idosos. Ela diz que se surpreendeu ao chegar a SP e ver quantos casos de Alzheimer existem. Segundo ela, no local de onde vem, nunca ouviu falar desta doença. Entre os indígenas então, é mais raro ainda. A única coisa que eles falam lá é que tal pessoa está meio esquecida, mas não acham isto uma doença e nem tratam com medicamentos. Ela veio para SP em 2013, mora no Brás, ao lado das igrejas evangélicas. Gosta de trabalhar na casa, pois ela tem pena da situação dos residentes e gosta de ser útil e carinhosa com eles. Lá existem 15 residentes, sendo 4 homens.

Saí de lá às 19h15min, todos tinham ido para os quartos.

$4^{\mathrm{a}}$. visita - Casa $1-01 / 08 / 2014-6^{\mathrm{a}}$.feira - cheguei às $10 \mathrm{~h}: 30 \mathrm{~min}$

Uma auxiliar abriu o portão e já me deixou entrar sem fazer perguntas. $\mathrm{O}$ responsável pela administração geral das unidades estava atendendo duas mulheres e pediu para eu esperar um pouco. Havia uma mulher chamada Cristina que chorava e reclamava o tempo todo. Em seguida o germe liberou para entrar, dizendo que eu poderia começar a observação e me pediu para não conversar com uma residente que acabara de ser deixada pelas filhas. Descobri depois que o nome dela é Aparecida e ela vai ficar em adaptação. Anotei o nome dela para que, na próxima etapa da pesquisa, eu converse com ela, pois me interessa muito este caso de pessoas recém-admitidas, pois têm meios de comparar com a situação anterior.

Fiquei na sala de estar onde havia 13 pessoas, sendo 12 mulheres. TV ligada, som muito alto. Cinco pessoas cochilavam, 2 conversavam, mas parecia conversa sem 
nexo; 2 olhavam a televisão, mas só olhavam, apesar de o programa ser movimentado e de variedades. As pessoas não se olham; várias parecem não ter mobilidade; todos bem magros. Duas auxiliares tentavam convencer Cristina a andar e ir tomar sol; ela desistiu de ir andando e voltou. Elas a colocaram na cadeira de rodas e a levaram para fora e ela continuou chorando e chamando sua mãe para vir buscá-la. Aparecida, que está em adaptação, fica sentada, braços cruzados, séria. É uma sala ampla, não tem odor, é clara; tem duas portas largas e o piso é de tacos de marfim. Mudei de posição para ficar mais perto de duas mulheres que conversavam, para saber o que elas falavam tanto. Mas neste momento uma começou a cochilar e a outra ficou parada com o olhar fixo no chão. Havia outra que fazia palavras cruzadas. Tudo quieto. A mulher em adaptação continua impassível; uma auxiliar trouxe suco de laranja para ela; ela agradeceu, bebeu, devolveu a caneca e agradeceu novamente. Uma das duas mulheres que antes estavam conversando e que começou a cochilar acordou. Olhou no relógio e disse para a que estava ao lado: "são onze e quinze". Seu nome é Nair e ela anda sozinha, mas com muita dificuldade. Ela saiu da cadeira e disse que ia se sentar perto de outra que estava fazendo palavras cruzadas. Mas ela se sentou lá e a outra continuou fazendo palavras cruzadas. O único homem da sala saiu do seu lugar e foi sentar em outra poltrona, mas continuou impassível. As auxiliares ficam transitando por ali, mas neste horário não há muito que fazer.

Desci para o andar onde ficam os residentes menos lúcidos e com maior dependência. Uns gritam, outros reclamam, xingam as auxiliares quando tentam mexer com eles. As fisionomias são de pessoas em estado de demência bem avançada. É uma sala grande, mas lotada, são cadeiras do tipo espreguiçadeiras acolchoadas e as pessoas ficam semi- deitadas e imóveis. Anexo à sala ficam 7 pequenos quartos com camas e biombos como em uma enfermaria; nestes quartos ficam pessoas com casos mais complexos ainda e que precisam de cuidados quase constantes. Na sala estão 11 pessoas, sendo 5 homens. Uma auxiliar entra na sala para fazer a barba dos homens; um deixa que ela faça tranquilamente; ela o chama de meu velho e é muito amável e cuidadosa. Outro ao lado blasfema o tempo todo e um terceiro pede gritando para este calar a boca e aí ele fala mais alto ainda. A moça que estava fazendo a barba dos homens vem atender Alice que reclama de muita dor no braço. A auxiliar percebe que há um pano apertando no braço dela e o desaperta um pouco a chamando de "meu amor" e 
a tratando com muito carinho. Há outra senhora que fica com o corpo completamente jogado na cadeira, fica com a língua para fora o tempo todo, bate palmas, resmunga, bate os pés e revira os olhos. As auxiliares cuidam de uma residente num dos quartos anexos, dão banho, fazem curativo. A auxiliar voltou a fazer a barba do José, mas ele fica jogado na cadeira e não quer que ela faça; ele reclama, xinga de demônio, fica com a língua para fora. Emiliano que se senta ao lado de José reclama dele e quando José grita "demônio", Emília fala "demônios da garoa". Com muita paciência a auxiliar o chama de "meu amor", diz que ele vai ficar bonito. Ele responde "p..., c..., inferno". Emiliano e outro senhor dizem para ele deixar que ela faça a barba dele porque amanhã é sábado e vêm mais visitas e ele tem que ficar bonito. Ele se acalma e deixa aos poucos a moça fazer-lhe a barba. Apesar de todos os que estão na sala usarem fraldas descartáveis, o ambiente não tem cheiro de urina, pois as auxiliares de limpeza ficam o tempo todo passando pano com desinfetante e limpando o local. A TV continua ligada, agora com volume baixo, ninguém presta atenção apesar de ser programa de variedades. Elas levam Emiliano para fora na cadeira de rodas e ao passar por mim eu o cumprimento. Ele pede desculpas, pois disse que não havia falado comigo, porque não tinha percebido que eu estava ali. Ele não tem uma das pernas. Uma mulher que está dentro de um dos quartos chora, um homem em outro quarto fica tossindo muito alto o tempo todo e faz barulho de que vai cuspir. Seis pessoas na sala dormem apesar de ser perto das 12 horas. As auxiliares passam, limpam e cuidam dos acamados tratando-os muito bem. Uma delas avisa que é meio-dia, mas ninguém parece aguardar o horário do almoço. Elas começam a ajudar a quem pode ir almoçar na mesa. Alice é levada na cadeira de rodas. Outra que se chama Ameli é chamada para ir pra mesa, mas ela reluta muito em aceitar. As moças a colocam na cadeira de rodas e a levam. Aí elas começam a dar almoço para os que ficaram. Arroz, feijão, filé de frango e salada de cenoura. Refeição com uma aparência muito boa. O primeiro homem, João, come bem. Dentro da comida elas colocam medicamentos para alguns. Aqueles que estão dormindo não acordam nem nesta hora. A senhora que vive reclamando não quer comer e grita com as auxiliares. Outro homem que não quer comer também grita com as moças. É um momento de muito trabalho. A Aline, a que faz as barbas, fica com os mais difíceis e ela vai com cuidado, vai conseguindo. Outras auxiliares só dão a comida sem conversar nada nem olhar para a pessoa; é uma tarefa de paciência, dar comida. A mulher que 
reclama manda Aline "tomar no...", manda que ela pare de dar comida, mas ela vai insistindo e a mulher vai comendo aos poucos. De todos os residentes somente três comem na mesa que fica no quintal e comem sozinhos, sem interagir. A ala do andar inferior é triste. Já no andar superior 8 pessoas comem no quintal e há uma certa interação. A mulher que está em adaptação, Aparecida, continua quieta, olhando para a parede. A casa como um todo é bonita, o quintal é bem amplo e tem plantas; é clara e não é fria, apesar de a temperatura pela manhã estar baixa. Quando saí de lá eles estavam terminando de almoçar.

Saí de lá às 12:30h.

$5^{\mathrm{a}}$. visita - Unidade 2 -01/08/2014 - $6^{\mathrm{a}}$.feira - cheguei às $15 \mathrm{~h}: 30 \mathrm{~min}$

Élida, a enfermeira da casa me atendeu. Eu já tinha vindo nesta casa, mas era hora de janta e todos logo começaram a pedir para ir dormir. Havia 9 pessoas na sala, 7 mulheres e 2 homens. TV ligada, som baixo. Somente um homem e uma mulher olham para a TV, mas sem nenhum interesse. Era hora do suco da tarde, as auxiliares iam trazendo em canecas plásticas. Uma mulher chamada Júlia recebe o suco, toma e agradece dizendo que está muito bom. Yoshii, a japonesa, reclama da comida do almoço dizendo que estava muito salgada e com muito fermento. Duas mulheres conversam, mas sem nexo. As auxiliares tratam os residentes pelo nome sem dizer senhor ou senhora. Uma mulher tenta colocar a manga da sua blusa dentro do suco. Outra morde a barra da blusa e uma terceira dobra e desdobra a própria roupa o tempo todo. Élida, a enfermeira, conversa com uma mulher, chamada Dulce, cuja aparência faz crer que é uma pessoa lúcida, mas a conversa segue um rumo completamente diferente a cada pergunta feita. Ela mantém a conversa sem parar. Enquanto conversa com Dulce, Élida corta as unhas de outra mulher, Josefa, que fica reclamando e chorando o tempo todo, fazendo voz de criança. Daí a pouco a Élida buscou três bonecas e deu para três mulheres. Vi que as bonecas eram delas mesmo. Elas adoraram. Uma das bonecas é aquela que fala e faz perguntas, dizendo: Você gosta de mim? Você quer brincar comigo? O que você comeu hoje? E a mulher vai respondendo às perguntas. As outras mulheres seguram suas bonecas como bebês sendo ninados e conversam com elas bem baixinho, chamando-as de filhinhas. Élida chama Otavio para passear no quintal, ele vai devagar. Antonio também vai. Está um dia bem claro e o quintal recebe sol. Yoshii 
dorme. Começa uma novela, apenas uma mulher assiste. Élida pega uma bolinha e brinca de jogar com a mão para o Antonio e o Otavio. Eles respondem à brincadeira e conseguem pegar várias vezes a bolinha que ela joga. Antonio grita: é gol, é gol, é gol, é gol... Antonio é aquele que à noite ficou batendo nas pernas e batendo os pés no chão e falando sem parar na visita anterior. Enquanto isto as três mulheres continuam conversando e ninando as bonecas, achando que são suas crianças. Entrou uma fonoaudióloga que veio para ajudar Josefa a comer. Josefa não quer comer nada sólido e cospe tudo para o chão enquanto a moça não a está olhando. Quando a moça tenta colocar comida na sua boca ela a fecha e fecha os olhos também choramingando que não quer comer. Uma auxiliar vem trazer os remédios de todos. Júlia é uma das que está com uma boneca. Para mim ela parecia muito lúcida, mas ao levantar utilizando uma bengala de quatro apoios ela segura a boneca na outra mão e vai até Etna que está com a boneca falante e pergunta como está a filha da Etna e quer saber o nome dela. Etna não responde. Josefa vai comendo aos poucos, mas a fono não tem muito sucesso no trato com ela. Parece que a fono tem menos jeito para tratar com a residente do que as próprias auxiliares e a Élida. Na casa há apenas um auxiliar do gênero masculino. Ele entra e vem buscar Yoshii para que ela vá jantar na mesa. Mas ele a deixa lá comendo sozinha. Uma coisa que me chamou a atenção é que poucos ali usam prótese dentária. A grande maioria tem seus dentes, ou melhor, alguns dentes e estes são muito mal conservados, havendo dentes quebrados, com cárie, escuros ou amarelos. Isto dá uma aparência totalmente deteriorada. Nas duas visitas a esta casa percebi que o ambiente fica totalmente diferente no horário da tarde. À tarde ele é mais leve e movimentado do que à noite. A sensação é de que o escurecer causa neles a impressão de que já é hora de dormir.

Já estava no momento do jantar e então fui embora. Deste ambiente saí tranqüila.

Saí de lá às 17 h30min e foi minha última visita desta etapa de observação. 


\section{B - IMAGEM DA APROVAÇÃO PELO COMITÊ DE ÉTICA}

Projeto de Pesquisa:

\begin{tabular}{|c|c|c|c|c|c|c|c|c|c|}
\hline$\frac{\text { Tipo }}{\hat{\leqslant}}$ & $\frac{\text { Número CAAE }}{\hat{\sim}}$ & $\begin{array}{l}\text { Título } \\
\underline{\text { Pesquisa }}\end{array}$ & $\begin{array}{l}\text { Pesquisador } \\
\underline{\text { Responsável }}\end{array}$ & $\frac{\text { Versão }}{\hat{*}}$ & $\begin{array}{l}\text { Ultima } \\
\underline{\text { Modificação }}\end{array}$ & $\underline{\text { Situação }}$ & \multicolumn{3}{|c|}{$\begin{array}{l}\text { Gestão da } \\
\text { Pesquisa }\end{array}$} \\
\hline $\mathrm{P}$ & $\begin{array}{l}38855714.9 .0000 \\
.5390\end{array}$ & $\begin{array}{lr}\text { ROTINA } & \text { EM } \\
\text { INSTITUIÇÕE } \\
\text { S DE LONGA } \\
\text { PERMANENCI } \\
\text { A } \\
\text { IDOSOS PARA } \\
\text { Estudo } \\
\text { possíveis } \\
\text { impactos so(...) }\end{array}$ & $\begin{array}{l}\text { EVANY BETTINE } \\
\text { DE ALMEIDA }\end{array}$ & 1 & $15 / 12 / 2014$ & $\begin{array}{l}\text { Aprovad } \\
\text { o }\end{array}$ & م & $\square^{\lambda}$ & + \\
\hline
\end{tabular}




\title{
C - ENTREVISTAS TRANSCRITAS
}

\author{
Entrevistas transcritas: (Nomes fictícios)
}

\section{Observação:}

Neste apêndice apenas a primeira entrevista foi colocada completa para conhecimento da aplicação do roteiro. Para não tornar este documento muito extenso, as demais entrevistas foram agrupadas em quatro grandes temas, conforme descrito no Capítulo 3.

As entrevistas ocorreram entre janeiro de 2015 e abril de 2016, em duas Casas de Repouso na zona leste e na zona sul de São Paulo.

1a. entrevista - Data 16-01-2015

Nome: Elisa (fictício)

Idade:85 anos, cognição preservada - sofreu queda há 5 meses em casa

Hoje é dia 16 de janeiro de 2015, eu estou aqui com Elisa e vou fazer algumas perguntas para ela. Elisa conte para mim como era a sua vida antes de você vir para cá, que horas você acordava, tomava café... como era seu dia?

R: A minha vida... era boa

P: Você achava a sua vida boa?

R: Me achava sozinha sempre, depois que faleceu meu marido, então, aí...

P: Mas era uma vida tranquila?

R: Era boa, tranquila, graças a Deus, sem preocupação, fora disso, qualquer coisa, era uma vida boa, porque eu tinha meu apartamento, entende...então eu me sentia tranquila, mas depois eu levei este tombo, aí eu não fui mais a mesma.

P: Depois do tombo você modificou?

R: Modifiquei, porque nem tudo eu podia fazer

P: Eu te já perguntei, mas você não se lembra direito há quanto tempo você está aqui, na verdade?

R: Bom, eu não vou saber responder

P: Depois eu pergunto para o pessoal da casa, você veio aqui, porque você estava com este problema e não podia se movimentar, você caiu e quebrou a bacia, certo? Quando você chegou aqui o pessoal te explicou, aqui a gente levanta tal hora, toma café tal hora, deita tal hora, alguém te explicou as regras do momento?

R: Nada

P: Você chegou entrou e foi tendo que se adaptar?

$\mathrm{R}$ : Conforme as enfermeiras que entram de plantão, tudo é conforme as que vão pegar o plantão, cada uma dá o seu jeitinho pra terminar o plantão.

P: Entendi, tem o jeito da própria funcionária, vamos dizer assim, mas ninguém chega e conversa com você no começo e explica direitinho tudo que acontece na casa?

R: Não

P: Entendi, Tem aqui uma regra que fala que você não pode sair, você não pode ir para a rua, tem alguma forma ou eles vão falando a cada vez que acontece alguma coisa?

R: Tem assim, por exemplo, que nem ela, nem tudo ela pode fazer, porque eles não admitem, tem que sempre chamar a enfermeira

P: No seu caso você tem sua cuidadora, essa moça, acompanhante?

R: Eu falo para ela, dói meu coração, tem umas duas plantinhas que sofrem com o calor, 
Cleuza , dá um pouquinho de água , eu não posso dona Elisa, eu não posso fazer nada disso aí, mas falei, dá um pouco de água pra planta, olha como elas estão sentindo; não,mas eu não posso.

P: Aí as enfermeiras vão dizer que ela está interferindo?

R: Diz ela que é isso

P: Mas uma coisa desse tipo assim é difícil...

R: Difícil...

P: Você já me falou um pouquinho, mas eu queria que você lembrasse direito, a qualidade do seu sono aqui não é muito boa por causa do horário, você é obrigada a ir para cama muito cedo...

R: Mas eu prefiro assim também, as vezes, para não ficar pensando outras coisas, ouvindo as vezes, algum barulho lá...

P: Lá na sala

R: Dentro, então eu faço força, fecho bem os olhos e rezo, rezo sempre meu terço, toda noite eu rezo meu terço, às vezes rezo meu terço mais de uma vez, então isso me faz bem.

P: Entendi

R: Quer dizer, só não gosto de acordar muito cedo, que nem às 5 hs da manhã, isso é muito cedo, porque é uma hora que a gente está num soninho bom, 5 horas da manhã, só isso... a luz e o barulho acordam a gente sem a gente querer. Aí eu fico 2 horas na cama até levantar.

P: Você me falou também que não está tendo muito apetite nas refeições?

R: Não estou, não tô, não tô, às vezes deixo a comida toda. Sopinha também, às vezes, deixo todinha, mas graças a Deus tem aquele chazinho que me dão às 8 da noite, que dão chá com umas bolachinhas, isto me salva um pouco, eu tomo e me sinto bem

P: E tem enjoo?

R: Não... hum... tenho enjoo

P: O enjoo, na verdade, vem com a quantidade de medicamentos que você está tomando?

R: Também, então.

P: A questão do horário da refeição, de dormir, de acordar, você foi tendo que se adaptar, com relação à sua casa era mais livre... complicado você ficar nestes horários aqui certinhos, é isso?

R: É

P: E o horário de dormir, é bom pra você?

R: Dormir às 6 e meia? Não dá... eu fico uma hora e meia até pegar no sono...

P: Porque você lá na sua casa tinha uma liberdade?

R: É, tinha meu sofá gostoso, minha televisão, até penso, meu Deus, acho que ninguém mais ligou, tá tudo parado..

$\mathrm{P}$ : É, porque tem que usar

$\mathrm{R}$ : Eu tenho muitas saudades, mas eu vou dar um jeito

P: vai né?

R: Ah vou, porque vou morrer assim? Ficar triste... eu tenho minha perna, me deixa mais um pouquinho lá, verdade

P: Agora que você já está melhor da bacia. Aqui eles tem um certo horário para as coisas, mas se eles falassem que você poderia escolher que horas você vai tomar café, almoçar...se você pudesse falar, como você falaria? Você falaria eu prefiro acordar as 7 , tomar o café em seguida...como seria o seu dia? 
R: Eles me dão o café antes do banho, porque assim eu já tomo o café que já está passando as 8:30, então eu tomo o café antes do banho. Quem toma banho sempre primeiro é a Rosita, que até hoje evacuou, não sei como foi, oh Rosita eles diziam, ainda falam, Rositinha do coração, você fez cocô? Mas, meu Deus, porque ela não fala que quer fazer, as vezes faz "ploc", cai no chão tudo

P: Ela não tem controle mais?

R: Não tem controle

P: Ah, chama Rosita sua colega de quarto?

$\mathrm{R}$ : É, se bem que as vezes que ela fica apertada, ela consegue segurar, ela é muito boazinha, então eu deixo passar tudo isso ai, fazer o que?

P: Verdade, e você, que atividades você acha que deveria ter aqui para você durante o dia, assim, ao invés de ter só televisão ligada, que você gostaria que tivesse ou que viesse um tipo de pessoa fazer alguma coisa com vocês aqui, como seria se essa casa fosse sua?

R: Ah, não sei

P: Você não pensou a respeito?

R: Não tenho mais vontade de nada

P: Mas vamos sonhar, essa casa passou a ser minha, hoje eu vou ser a gerente desta casa, o que eu vou chamar para fazer para os outros e para mim mesma, vou chamar uma pessoa para fazer uma atividade alegre, o que você pensaria, qual seria seu sonho?

R: É música, eu gosto muito de ouvir, como nós temos um cantor que vem toda semana

P: Vocês tem um cantor, mas você gostaria de ter mais vezes?

R: Mais vezes, seria uma coisa maravilhosa

P: Ele toca violão também?

$\mathrm{R}$ : Toca violão, aquele violão dele velhinho, aquelas coisas tudo velhinhas acho que ele tem tanto amor pelos instrumentos dele que ele não troca, não se desfaz de jeito nenhum, a gente vê que tá ..., seu eu pudesse compraria um violão novo para ele.

P: Como ele se chama, você sabe?

R: Não sei, não guardo nome.

P: Você precisa perguntar, para depois me contar

R: Vou perguntar

P: Ai você fala com o nome que fica mais bonito

R: Vou perguntar, vem uma quarta-feira, vem...

P: É de quarta-feira que ele vem?

$\mathrm{R}$ : É quarta-feira que ele vem

P: Na próxima vez que eu vier fazer entrevista, eu venho de quarta, ele vem de tarde?

R: A tarde

P: Pelo que você esta me falando, você gosta tanto desta atividade que teria mais vezes?

R: Mais vezes, todos, eu sinto, todos, tem uma senhora que o filho dela falou: "mãe (um dia eu escutei, acho ele ficou nervoso) mãe a senhora só dorme? Dorme sentada, dorme na cama, só dorme?", e ela aquele dia que veio o cantor, foi a primeira vez que ela viu o cantor, como ela estava alegre, como ela se sentiu alegre, ela falou: "nós temos que preparar alguma coisa para quando ele vier, para ele tomar, para ele depois que ele tocar ele se sentir bem", agora já pensaram assim, vamos comprar sorvete, vamos dar sorvete para ele

P: Que ideia boa

R: Eu gosto, e esta senhora... esta aí

P: A que estava dormindo, acordou porque teve uma atividade alegre 
R: Sempre triste, sempre triste, agora está alegre, assim é que conheci ela... antes não.

P: Entendi, gostei...

R: Venha então, para você ver se eu não tenho razão

$\mathrm{P}$ : Eu venho, sim, uma quarta-feira à tarde

R: Uma quarta-feira, mas venha sim, não sei o horário que ele vem, umas 2 e ...

P: Eu venho 2 hs para ficar até às 5, vou encontrar com ele

R: Ele toca um tempinho só, depois vai embora, mas é muito bom

P: Ah, uma coisa que eu tenho que perguntar como é o passar do tempo pra você aqui, passar o dia, os dias, as semanas, os meses?

$\mathrm{R}$ : Eu só não gosto, quando vem chegando a noite

P: A noite, você não gosta

R: É, estou sentindo um pouco as costas

P: Já está cansada, daqui a pouco a gente levanta, eu vou embora

R: O passar do tempo, você disse?

P: É, você acha que o tempo se arrasta, passa rápido demais, que tem dia que você não gosta, tem dia que você gosta, a sensação do tempo?

$\mathrm{R}$ : Eu acho que ele demora para passar

P: Você acha que ele se arrasta

$\mathrm{R}: \mathrm{Eu}$ acho

P: Você acha?

R: Eu acho, e eu não gosto da noite, por exemplo, quando eu vou deitar tudo, e eu não gosto da noite, não vejo a hora que passa

$\mathrm{R}$ : Por isso que eu queria dormir

P: Dormir melhor?

R: Dormir aquelas horas de sono e acordar só quando que elas entram, ou qualquer coisa assim que precise fazer, mas do resto, não tenho mais ...

P: Não gosta de ficar muito e muito tempo

R: Tenho muitas saudades dos netos, eu te mostrei alguma foto dele?

P: Ainda não

R: Agora eu não sei aonde ela ( $a$ acompanhante) guardou, eu tirei para dar mais espaço, que coisa mais linda, mas moraram muito tempo nos EUA, agora eles estão na Argentina que o marido da minha neta foi transferido para a Argentina, então... é longe

P: Longe demais

R: É longe... tenho só um netinho que é da Fernandinha, que está aqui, o Felipe, mas a... imagine que eu esqueço o nome da minha bisneta, que são meus bisnetos, não são netos P: Bisneto já é longe

R: E o Luca, e o Luca, tenho muita saudade, muita saudade... a minha bisnetinha é loirinha, loirinha, precisa ver que lindinha, que coisa, veio com o cabelo bem loirinho

P: E olhos claros?

R: Não tem olhos claros, castanho, mas é escuro

P: Interessante, né, loira, deve ficar lindo

R: Loirinha bem loirinha, e o Luca que é um menino muito inteligente, pois fala português, fala espanhol e fala inglês, ele entende, o pouco que ele tem, se o pai fala com ele em inglês ele responde para o pai em inglês

$\mathrm{P}:$ Ele tem quantos anos?

R: O Luca tem 6 aninhos e agora fala todas estas língua e ainda o menino... já esqueci o que eu queria falar para você

P: Você estava falando de todos, que seu netos são inteligentes, bonitos... 
R: Muito inteligente, o Luca é muito inteligente...

$\mathrm{P}$ : E você tem muita saudade deles

R: Muita saudades ... a minha neta, deixa eu ver se ela deixou aqui em cima, eu mostro para você. Preciso endireitar minhas costas. Está é minha neta Andrea, mãe deles, olha minha bisnetinha, este meu bisnetinho que é inteligente, este é da outra, da Fernandinha, desta aqui, olha minha filha e esta sou eu

P: Muito lindas, todas lindas

R: É. Graças a Deus nem fale, antes de dormir eu olho bastante para rezar para eles. Não é gostoso ter netinhos, bisnetinhos?

P: Deve ser uma maravilha

R: É, então.

P: Tá bom então, por enquanto é isso, se tiver alguma coisa mais que você lembre, que você queira falar para mim, senão outro dia que eu vier, se você lembrar de alguma coisa, que quiser me contar e tal, vou gravando todas as histórias e fazer um livro de histórias. Estamos encerrando agora obrigada Elisa, hoje é dia 16/01 /2015, são 16:11. Obrigada Elisa.

R: Obrigada você, me desculpe alguma coisa, às vezes já me torno uma pessoa, sei lá, não sei mais conversar, não tenho mais, não sei mais me portar em certas coisas.

P: Você foi muito bem, foi ótima, obrigada Elisa

R: Obrigada você.

A seguir agrupei os quatro assuntos e localizei neles as falas que se relacionavam com os assuntos

$\checkmark$ Rotina antes da institucionalização

$\checkmark$ Tempo na instituição e forma de ingresso

$\checkmark$ Rotina na instituição (tempos sociais), sono, apetite

$\checkmark$ Rotina que seria ideal e passagem do tempo na instituição

\section{ENTREVISTAS TRANSCRITAS POR ASSUNTO}

\section{Tema 1 - Rotina antes do ingresso}

-Antes a minha vida era boa, mas fiquei ruim do joelho... não pude andar mais e minha cuidadora ficou doente... foi embora... não tinha quem cuidasse de mim, meu filho me trouxe

-Fazia todo meu trabalho em casa, acordava cedo, mas não tinha hora... vida boa

- Meu dia era normal, acordava cedo, lia jornais... quem entende de política precisa ler jornais... até hoje meu sobrinho traz o jornal aqui porque sou assinante; ficava em casa... era tranquilo. 
-Fazia tudo em casa, mas fui ficando sozinha... fiquei 5 anos sozinha, era muito triste

-Tinha minha casa, meus horários, era livre.... mas era só eu.

-Fazia o que queria e pronto

-Minha rotina era pelo horário dos outros que trabalhavam... os filhos, os netos. Quem trabalha tem que ter tudo na hora certa e eu ficava em casa.

-Dormia cedo, mas acordava a hora que queria.. isto era melhor. Não saia de casa. Era isto mesmo que tem aqui.

-Morava sozinha, não tinha mais como ficar sozinha, mas tinha minha rotina que eu fazia.

-Antes de vir pra cá, trabalhava em casa mesmo, fazia as coisas... os horários sempre eram como nos tempos de trabalho... não precisava, mas era igual quanto todos trabalhavam... mas aí fiquei doente.

-Gostava da minha vida, mas fiquei doente e quem ia cuidar de mim? Mas antes de ficar doente, era livre de horários, comia e dormia quando queria.

-Tudo num ritmo. Dormir, acordar, fazer coisas e comer.

-Tinha liberdade e saía bastante... era rotina, mas não era obrigação.

-Lá em casa, ou aqui eu gostava de tudo certinho.

-As pessoas trabalhavam e a gente que não trabalhava seguia a rotina deles... afinal o trabalho é que manda. Mas eu dormia um pouco mais tarde, mas conseguia acordar cedo pra rotina... dormia pouco mesmo... hoje também durmo pouco... a gente vai ficando mais velho é assim. 
-Minha rotina era bem parecida com essa... mas não tinha que ir pra cama ainda com claridade.

Bom, eu não tinha praticamente horário certo, acordava 9, 9 e meia, às vezes até 10 hs, depende o horário que eu ia dormir, se eu ia dormir 2 hs, 3, depende, ficava assistindo os filmes, que eram interessantes, quando ia me dar o sono, quando dava o sono ai eu ia dormir...

-Rotina de horário você fala? Ah não tinha não... acordava cedo, mas era quando meu corpo pedia, almoçava um pouco mais tarde quando tinha fome... tinha liberdade, sabe?

-Rotina tinha, mas era diferente... tinha horário por causa do trabalho dos outros ou da escola dos netos... só que acordava sozinha e dormia quando tinha sono.

-Meu dia era igual sempre

\section{Tema 2 - Tempo de residência na instituição e forma de ingresso}

-Faz 4 anos... vou ficar aqui... meu filho achou aqui. Não tem cuide de mim, todos trabalham.

- Faz 6 meses. Minha filha veio conhecer... eu não conhecia. Nunca precisei de abrigo, graças a deus... agora não sei daqui pra frente.

- Faz 4 meses. Vim pra cá porque minha esposa está com Alzheimer então pago um quarto só pra nós dois e aqui tem quem cuide dela. Tenho 97 anos e somos casados há 74 anos. Ela não me reconhece mais, isto me mata. Mas eu sei quem ela é e o que ela fez por mim e a família, por isto vim pra cá junto com ela. Todos os parentes morreram, só ficamos nós dois.

- Três anos. Vim para cá para não viver sozinha. Mas estou com saúde. 
-Dois anos, morava sozinho e não podia mais ficar sozinho, fazer as coisas... tenho 90 anos. Me colocaram aqui.

-Dois anos, vim para cá porque eu quis... vendi minha casa e vim aqui num quarto particular.

-Dois anos... vim pra cá para não dar trabalho, mas eu falei pra eles que eu estava querendo vir...

-Mais de dois anos, vim porque não conseguia mais andar direito. Não queria dar trabalho para os outros; todos trabalham, têm sua vida... fazer o quê?

-Oito meses, fiquei doente, não tinha quem cuidasse, tiveram que me por aqui.

-Um ano e meio... me trouxeram aqui para não viver sozinha. Mas tenho sáude.

-Não sabe há quanto tempo... veio porque ficou acamada

-Um ano, disseram que eu ia para uma clínica pra fazer um tratamento que o médico mandou e depois ia voltar... acho que não, porque nem teve tratamento.

-Três meses... estou me recuperando da fratura do fêmur. Mas assim que eu andar, vou embora rapidinho, aqui é bom, mas não é uma casa.

-Quatro anos, vim porque quis, fiquei viúva e aluguei minha casa... pago aqui um quarto particular, faço meus trabalhos manuais, vendo... e ainda sobra dinheiro.

-Oito meses. Minha filha me pôs no carro e falou vamos dar uma volta. A gente brigava muito, mas naquele dia não. Aí chegou aqui ela disse vai lá com aquelas moças que eu já volto... hoje ela vem me visitar e eu digo que não tenho mágoa, pra não deixar ela triste, mas é mentira. As moças me deram a maior força aqui. 
-Nove meses. Caí e quebrei o braço, não tenho filhas só dois filhos homens e eles não sabem o que fazer. No fim das contas, vim parar aqui, mas se este meu braço me ajudar eu saio. Bem feito pra mim... eu só quis ter 2 filhos, se tivesse mais quem sabe vinha uma menina e eu não precisava vir pra cá...

-A gente fica velho e a família vai morrendo, não tenho filhos, não quis casar, então um sobrinho me trouxe para eu poder ser cuidado aqui. Eu estou porque não tenho família... mas tem muita gente aqui que tem família e está aqui também, né?

-Aqui é bom, é como uma casa... a gente dá um jeitinho com as coisas... consegue sentar num lugar melhor, uma bolachinha a mais... ficar um pouco mais na cama... na base da conversa.

-Nesta sala com toda esta gente misturada... olha as pessoas não conseguem mais nem ficar sentadas, nem andar, outros ficam falando alto, olhos perdidos, babando... para todo lado que a gente olha é isto... e a gente vai ficando, sei lá... é o tempo todo só vivendo isto... como você acha que a gente vai ficando?

- Quatro meses. Fiquei doente... então a esperança da gente se curar, aqui todo mundo sente a mesma coisa, eu tenho a impressão que é isso, eu sinto, é uma esperança que eu tenho, acabou e ir para minha casa, mas eu continuo com saudades e choro todos os dias, agora diminuiu um pouco, mas eu choro, eu sinto saudades do meu lar, de tudo.

-Uns meses... tanto faz saber. Vim porque morava sozinha, tenho mais de 90 e não queria dar trabalho pra ninguém.

-Um ano, não lembro direito... me trouxeram (filhos) e falaram que ia ser melhor por ter quem cuidaria de mim

-Um ano e meio sei direitinho. Eu pedi pra acharem um lugar pra mim. Não queria dar trabalho pros outros. 
-Oito meses. Meus filhos arranjaram este lugar, mas disseram que só ia ficar se eu gostasse... quando eles vêm, eu digo que estou bem, mas quando eles vão embora meu coração fica apertadinho...

- Uns meses... eu pedi. Eles prometeram que iam vir sempre. No começo deu certo e a gente passava boas horas. Depois não deu mais pra eles... sabe o trabalho, né... agora só vem uma filha e sempre na correria.

-Se faz um mês, um ano? Tanto faz. Vim porque teria companhia, mas é cada um por si e as moças trabalhando, trabalhando.

Tema 3 - Tempos sociais da instituição, sono, apetite...

\section{$>$ Regras}

- Como estou há bastante tempo pra mim não tem regras, posso dormir a hora que quiser, mas acordar acordo cedinho pras enfermeiras arrumarem a gente, porque vem o outro plantão às 7. Elas querem deixar a gente limpinho pras outras e a gente ajuda elas. Mas aqui ninguém me falou você tem que fazer isto, aquilo.... mas a gente precisa ajudar as meninas.

-Me explicaram os horários quando entrei, acho tudo normal, mas a gente é obrigada a aceitar, né?

-Regras? Não precisa explicar... a regra é ficar aqui... nesta sala com toda esta gente misturada... olha as pessoas não conseguem mais nem ficar sentadas, outros ficando falando alto, olhos perdidos, babando, para todo lado que a gente olha é isto... e a gente vai ficando, sei lá... é o tempo todo só vivendo isto.

- Não me explicaram nada, de manhã a gente escuta já de longe a televisão ligada, pega e levanta, a gente levanta e tem que sentar aqui porque não tem aonde ir 
- Pra mim aqui não tem nada de regras obrigatórias, pois levanto a hora que quero, na hora certa vem a comida, café, tudo. Sabe, eu posso pedir as coisas paras as enfermeiras, eu fico num quarto particular, é diferente.

-Aqui é bom pra mim, tenho amizade com as enfermeiras... elas são boazinhas pra mim.

-Sigo a rotina deles, hora de almoçar é boa, café, tudo está de acordo.

-Fico sozinho no último quarto e quanto mais sozinho melhor. Não quero ficar com ninguém... depois que minha esposa morreu não quero mais nada. Tenho 93 anos.

-Rotina normal, não me atrapalha, durmo às 8 e acordo às 6 , tá bom.

-Rotina certinha, não sei as horas das coisas... só sei quando elas me chamam pra comer.

-Minha rotina aqui é isto que você tá vendo...tudo igual aos outros, mas nunca junto. Quer dizer, é junto, mas é sozinha cada um, entende?

-Quem fica na cama, é tudo igual, dorme, acorda, dorme.

-Aqui é sempre assim, mas é bom porque aqui nesta casa de repouso só tem mulher. É chato a gente ter que viver com outros homens depois de passar a vida só com o marido... quando tinha marido a gente nem podia ficar perto de nenhum outro homem. Eu estava em outro asilo antes, mas tinha homem e eu falei pro meu filho "aqui não fico, quero ir pra um lugar só de mulheres"... agora está bom.

-A gente faz o que as enfermeiras falam, elas... elas são os mandantes aqui

\section{Sono}

-Durmo bem... acho que não tomo remédio pra dormir, só pra dor. Vou dormir sempre mais tarde que os outros... eu fico até umas dez da noite na sala. As meninas, meninas é 
modo de falar, as enfermeiras... ela falam que durmo bem. Se elas dão remédio eu não sei, elas não falam nada.

-Durmo bem, mas demoro pra pegar no sono. Vou dormir mais tarde que os outros, às 10, 10 e meia da noite e acordo 6, 7 horas.

-Durmo a hora que quero, não fico na sala com os outros, tenho TV no quarto... às vezes acordo assustado porque outra paciente grita e eu penso que é minha mulher

-Não sei se tomo remédio pra dormir, mas acho que durmo bem... vou dormir um pouco mais tarde que os outros e aí é melhor.

-Meu sono é mais ou menos. Vou cedo pra cama, antes das 7 , demoro pra pegar no sono e depois levanto às 7 e meia da manhã, mas tá bom.

-Quase não durmo.

-Durmo bem, mas acordo muitas vezes à noite.

-Durmo muito de noite e acho que de dia também, pois as enfermeiras têm que me acordar pras coisas.

-Sono é mais ou menos... sono leve, barulho, gente gritando, enfermeiras e luz, tudo acorda a gente.

-Sono de quem fica na cama o tempo todo? É só sono mesmo.

-Tenho muito sono e durmo cedo. E de manhã depois do café sento e durmo, quer dizer cochilo, mas elas têm que me acordar porque não percebo a hora das coisas. 
- Sono parece que todo mundo tem aqui... quando é de tardezinha parece que bate um desespero e todos querem ir dormir antes das 7 da noite... parece que a gente vai ter um dia diferente amanhã e toda a tarde é assim.

Meu sono é leve... tudo me acorda... de manhã então às 5 começa a rotina. É barulho, é luz, é gente pedindo pra levantar, são as enfermeiras querendo ir ajeitando a gente pro turno novo... elas querem deixar a gente certinho pra escrever no caderno. A gente ajuda e deixa elas fazerem o que precisa com a gente, porque elas têm que entregar a gente limpinho para o outro plantão.

\section{Apetite}

-Não tenho muito apetite, gosto mais do lanche e do café, sempre tem um bolo que a gente pede, uma bolacha...

-Eu não gosto da comida daqui, nem um pouquinho, meu deus do céu. A única coisa que eu como bem é a verdura... É, a salada e eles põe frango, mas um frango cozido na agua, não dá gosto, credo eu não quero aquilo, eu gostaria do frango fritinho.

-Não tenho muita fome não... a gente vai comendo um pouco e tá bom

-Eu como bem, é pouco, mas tá bom

- Eu trago coisas de fora, elas guardam pra mim. Não tenho fome nas refeições, então eu como o que eu trago.

-Tenho apetite sim, como tudo o que vem.

-Quase não como... mas vem comida certinho.

-Não tenho apetite, mas a comida é boa.

-Como bem, faço tudo direitinho como eles mandam. 
-Fome tenho pouca, mas sempre como uma coisinha.

-Geralmente como 4, 5 coisas, arroz e feijão mais alguma mistura assim gostosa, então são 4 coisas, eu misturo ó e mando brasa, eu esvazio o prato... mas no começo eu não sentia fome... um mês eu fiquei sem comer, depois fui sentindo vontade.

-Quem está acamado, não tem apetite... come por obrigação.

-A hora do almoço é boa pra mim... tudo prontinho na mesa... pra quem teve que fazer isso pros outros a vida toda, eu acho uma maravilha... e se a gente elogia também agrada as moças e até consegue um tratamento especial.

-Elas tratam a gente bem aqui... é vovozinha pra lá, vovozinha pra cá... come tudinho pra ganhar o docinho depois... é que a gente não pode devolver o prato cheio, sabe?

-Não tenho fome nenhuma... vejo os outros comendo com uma vontade e tenho até inveja, mas parece que é tudo a mesma coisa, mesmo sendo diferente.

\section{Assunto 4 - Rotina ideal, horários e o "passar do tempo" Atividades que gostaria:}

- Não quero sugerir nada, ninguém ia aceitar, ninguém gosta de ser mandado.

-Não mudaria nada, está tudo de acordo, mas eu faria algum trabalho manual... eu gostava de bordar.. mas bordar pra quê, não tenho vontade, então eu assisto muita televisão.

- Não mudaria nada, nem colocaria atividades, as pessoas estão aqui é porque querem... se eu não quiser mais ficar aqui, vou embora... eu não mudaria nada, sua pergunta não tem lógica, como vou interferir na casa?

-Eu faria pintura naqueles livros, faço muitas palavras cruzadas. Não mudaria nada, ninguém ia querer fazer comigo então faço sozinha. 
-Se eu mudaria algo? E quem ia aceitar? Eu acho que é cada um na sua. Aqui é um aglomerado... não é bom, mas tanto faz, porque não converso com ninguém e ninguém conversa também.

-Não quero dar nenhuma sugestão, eu não gosto de atividades. Fui músico durante 50 anos e hoje tenho raiva de ouvir. Minha mulher gostava de uma valsa que eu tocava. Quando ela morreu prometi não tocar nunca mais. Eu tenho 93 anos... pra quê viver tanto?

-Alguma atividade? Talvez crochê, mas ninguém gosta...então é isso, não muda nada.

-Não quero atividade... pra mim nem pra ninguém.

-Não mudaria nada, não tenho nada, não faço nada.

-Não tenho capacidade pra sugerir nada de diferente... quer saber? Pra quê ter atividade? Não tenho ideia de alguma coisa que a gente iria gostar.

-A rotina ideal pra mim seria se eu pudesse um dia ou outro mudar o horário de almoço e jantar, se pudesse escolher uma coisa pra comer, sabe... como se eu fosse rainha... mas tá bom, a gente tem é que agradecer.

-Não gostaria de ter mais atividade... tem a terapeuta que vem todas as tardes, ela traz muitas coisas diferentes pra gente fazer, tem o dia da beleza, dia da conversa, da pintura, acho que tem mais algum, mas não lembro... eu faço tudo, está bom assim.

-Eu gostaria de ler e escrever que eu adoro, só que eu estou com problema de vista, então eu vou marcar um oftalmologista, domingo que vem meu sobrinho vem e eu vou pedir para marcar, porque eu tenho convênio, médico particular, médico que eu conheço há muitos anos 
-Olha porque eles não fazem uma atividade igual a desses dias... veio uma nutricionista e fez a massa de biscoito e todo mundo enrolou seu biscoitinho e depois ela assou pra gente comer no café... todo mundo que podia participou e foi uma tarde legal... outro sábado ela veio de novo e todos fizeram pizza de pão pulman... cada um foi cobrindo o seu pedaço na forma ela colocou os temperos e depois todos comeram. A gente fez junto e comeu junto. Isso foi diferente de sentar perto pra almoçar.

\section{$>$ O passar do tempo:}

- Todo dia, todo tempo a gente tem um dia ruim, às vezes tá tudo bem e acontece uma coisa ruim. Mas pra mim até que está bom, eu estou há bastante tempo aqui... às vezes eu fico olhando as velhinhas que têm aqui... velhinhas porque tem 95, 97 anos... e eu penso, meu deus eu podia morrer agora. Eu olho pra os outros que estão dando trabalho e penso não quero dar trabalho para ninguém, mas o que vier eu tenho que aceitar... não posso fazer nada.

- O tempo passa normal... mas se viesse alguém me ver, falar comigo, mas quem? Ninguém tem tempo pra nada, só trabalha.

-Como passo o tempo? Leio, assisto TV, tenho meu quarto, não dependo deles...

O tempo passa igual lá fora oras... se eu faço as mesmas coisas... é tudo igual.

-O tempo a gente sabe que vai passando, mas não vê.

-O tempo? Não penso nele e ele vai passando...

-Queria que o tempo passasse mais rápido para chegar logo a minha hora, mas ele não passa.

-O tempo se arrasta, mas todo domingo vou almoçar na casa do meu filho... à tarde ele me traz.. ai é rapidinho.

-Não vejo o tempo passar... só sei que acaba um dia e vem o outro. 
-Não demora, porque eu passo o tempo rezando, rezo por todos, leio livro católico, por isto agradeço a deus por estar onde estou.

-Estou aqui nesta cama... e você pergunta como é passar o tempo... se o tempo se arrasta? O que você acha?

-Tenho relógio... não preciso, mas é costume. Fico olhando toda hora... não adianta porque sei que o tempo vai demorar a passar. Mas olha, quanto eu ficava em casa, eu também achava isto. Só não lembro como era quando eu era mais nova.

-Que adianta perguntar se o tempo passar rápido ou se arrasta? Amanhã você vem de novo perguntar a mesma coisa...

-Os dias são sempre iguais, mas quando é sábado a gente sabe. Até as moças trabalham mais alegres. Elas estão sempre cansadas, essas enfermeiras. São sérias de tanto trabalhar.

-A gente só sabe que o tempo passa porque vêm as enfermeiras da manhã e falam bom dia, mas não sabe que horas são... aí vem as coisas para comer, suco, almoço, café, janta... aí sabe que passou um dia.

-Aqui chama casa de repouso, mas é chato a gente ficar sem fazer nada, passando o tempo à toa... sem poder trabalhar a gente é inútil, não serve pra nada... é que a gente não aprendeu a fazer nada... só trabalhar.

\section{$==$ Fim dos textos das entrevistas $==$}

Minhas observações: Os relatos colhidos e as observações realizadas sobre os tempos sociais na instituição tiveram a finalidade de identificarmos se esses tempos sociais estão dessincronizados com os tempos biológicos dos residentes. Porém, após analisar todos os relatos, podemos inferir que se houvesse alguma ação, ou ações da instituição ou dos próprios indivíduos para que os dois tempos fossem sincronizados, isto por si só 
não seria o fator determinante para melhorar a vida no asilo. Concluímos que essas ações seriam importantes, mas muitas outras seriam necessárias para superar os demais obstáculos que a vida nas instituições asilares avaliadas representa para os residentes. 
ANEXOS

\section{A - Carta para as instituições informando sobre a realização da pesquisa}

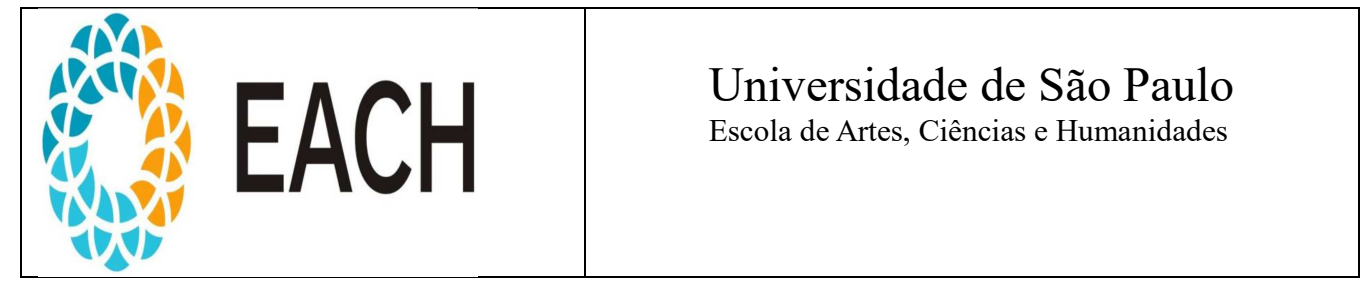

$\grave{A}$

Casa de Repouso

São Paulo - SP

Ref. Apresentação de pesquisadora na área de Gerontologia

Prezados Senhores

Esta carta tem por finalidade apresentar minha colaboradora, Evany Bettine de Almeida, gerontóloga pela Escola de Artes, Ciências e Humanidades da Universidade de São Paulo (EACH/USP), da qual sou docente.

Evany está envolvida em um projeto de pesquisa sobre rotinas em instituições de longa permanência para idosos, tema que se constituirá em projeto de dissertação de mestrado junto ao Programa de Pós-Graduação em Estudos Culturais da EACH/USP. Com esta apresentação sugiro encontro no qual ela possa apresentar seu projeto de pesquisa e discutir a possibilidade e conveniência de aplicá-lo na instituição dirigida por V. Sas.

Agradeço a atenção colocando-me ao vosso inteiro dispor para eventuais esclarecimentos.

Prof. Titular Luiz Menna Barreto

EACH/USP

Tel. 3091-8831 e-mail: menna@usp.br

São Paulo, 
B - Carta para as instituições pós Comitê de Ética

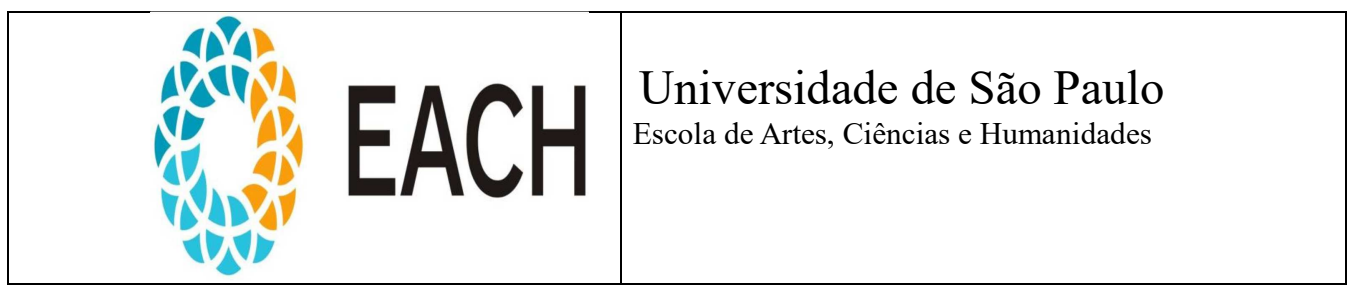

$\grave{A}$

Casa de Repouso (1)

At.

Ref. Pesquisa - Após aprovação do Comitê de Ética

Prezados Senhores

Data:

Em carta anterior já apresentei minha colaboradora, Evany Bettine de Almeida (Eva), gerontóloga pela Escola de Artes, Ciências e Humanidades da Universidade de São Paulo (EACH/USP), da qual sou docente.

Eva está envolvida em um projeto de pesquisa sobre rotinas em instituições de longa permanência para idosos, tema que constituirá sua dissertação de mestrado. Após a Eva ter feito a etapa inicial da observação "in loco", à qual chamamos de Observação Selvagem, foi necessário aguardar a aprovação do Comitê de Ética em Pesquisa com Seres Humanos da USP. A pesquisa foi aprovada sob número 38855714.9.0000.5390 e somente após esta aprovação é permitido fazer as entrevistas e aplicar os instrumentos nos residentes.

A partir de agora poderemos definir juntamente com vocês quais pessoas podem participar do desenvolvimento do trabalho. Inicialmente precisaremos da participação de duas pessoas para avaliarmos os instrumentos.

Agradeço a atenção colocando-me ao vosso inteiro dispor para eventuais esclarecimentos.

Luiz Menna Barreto

Prof. Titular - EACH/USP

Tel.3091-8831 e-mail: menna@usp.br 


\section{C - Termo de Consentimento Livre e Esclarecido - Idosos}

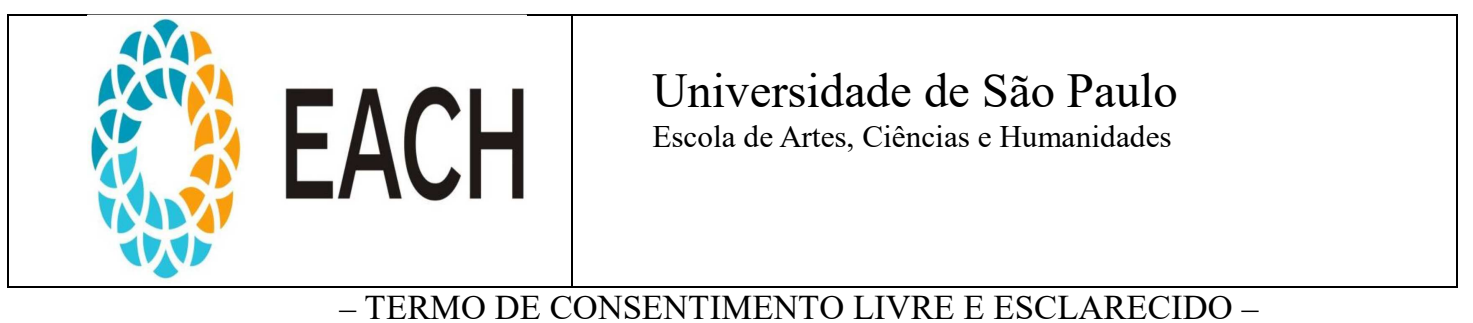

PROJETO DE PESQUISA: ROTINA EM INSTITUIÇÕES DE LONGA PERMANÊNCIA PARA IDOSOS: ESTUDO DOS POSSÍVEIS IMPACTOS SOBRE OS RITMOS BIOLÓGICOS DOS RESIDENTES QUE SÃO SUBMETIDOS A ESTA ROTINA.

ORIENTADOR: Prof. Dr. Luiz Silveira Menna-Barreto

PESQUISADORA: Evany Bettine de Almeida - Mestranda em Estudos Culturais

Escola de Artes, Ciências e Humanidades da Universidade de São Paulo - EACH/USP

Esta pesquisa faz parte da Dissertação de Mestrado

1. OBJETIVOS DESTA PESQUISA:

Nesta pesquisa pretende-se estudar as rotinas às quais idosos residentes em Instituições de Longa Permanência estão submetidos, investigando possíveis interferências na organização temporal dos ritmos destes residentes,

2. PROCEDIMENTOS:

O participante será convidado a responder questionários informativos de seus dados pessoais e de saúde, preferências por atividades, e hábitos de sono e depois gravar um relato livre da sua experiência desde que passou a residir na instituição.

\section{PossíVEIS RISCOS:}

Durante a realização da pesquisa e gravação das entrevistas os riscos são mínimos, tais como possível alteração de humor, inquietação, ou perda de ânimo para responder às questões. Estas condições podem ser contornadas pela pesquisadora, dando liberdade para interromper a entrevista ou aguardando um melhor momento para dar continuidade aos trabalhos.

4. CONFIDENCIALIDADE:

As informações fornecidas serão sigilosas, assegurando-se sua confidencialidade e privacidade.

5. PARTICIPAÇÃo VOLUNTÁRIA:

A participação é voluntária. Mesmo assinando este termo, você poderá interromper sua participação no estudo, a qualquer momento, sem que isto lhe traga qualquer prejuízo.

\section{ASSINATURA DO TERMO:}

Este Termo será impresso e assinado em duas vias, uma das quais permanecerá com o pesquisador e a outra será entregue ao participante da pesquisa.

\section{CONSENTIMENTO PÓS-ESCLARECIDO:}

Declaro que eu,

fui esclarecido pela pesquisadora, entendi o que me foi explicado e consinto em participar da pesquisa em gravação, fotografia e/ou filmagem, autorizando a divulgação das informações prestadas em eventos e artigos científicos.

São Paulo, de de 20

\begin{tabular}{ll}
\hline Assinatura do(a) Participante & $\begin{array}{l}\text { Pesquisadora Responsável } \\
\text { Evany Bettine de Almeida (11) 9 9600-4115 } \\
\text { Email: eva.bettine@,usp.br }\end{array}$ \\
Comitê de Ética em Pesquisa EACH: $\underline{\text { cep-each@usp.br (11) 3091-1046 }}$
\end{tabular}




\section{D - Termo de Consentimento Livre e Esclarecido - Profissionais}

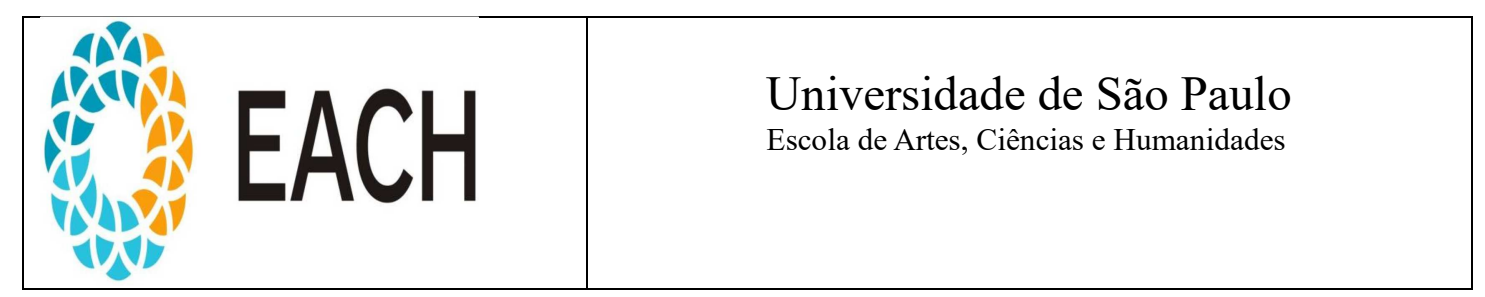

- TERMO DE CONSENTIMENTO LIVRE E ESCLARECIDO -

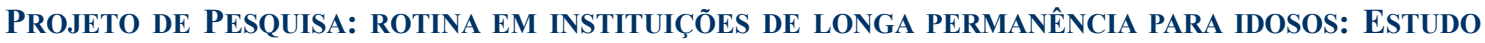
DOS POSSÍVEIS IMPACTOS SOBRE OS RITMOS BIOLÓGICOS DOS RESIDENTES QUE SÃO SUBMETIDOS A ESTA ROTINA.

ORIENTADOR: Prof. Dr. Luiz Silveira Menna-Barreto

PESQUiSAdORA: Evany Bettine de Almeida - Mestranda em Estudos Culturais

Escola de Artes, Ciências e Humanidades da Universidade de São Paulo - EACH/USP

Esta pesquisa faz parte da Dissertação de Mestrado

\section{OBJETIVOS DESTA PESQUISA:}

Nesta pesquisa pretende-se estudar as rotinas às quais idosos residentes em Instituições de Longa Permanência estão submetidos, investigando possíveis interferências na organização temporal dos ritmos destes residentes.

\section{Procedimentos:}

O profissional será convidado a responder um questionário com informações da sua função na instituição.

\section{POSSÍVEIS RISCOS:}

Durante a realização da pesquisa os riscos são mínimos, tais como possível alteração de humor, inquietação, ou perda de ânimo para responder às questões. Estas condições podem ser contornadas pela pesquisadora, dando liberdade para interromper a entrevista ou aguardando um melhor momento para dar continuidade aos trabalhos.

\section{CONFIDENCIALIDADE:}

As informações fornecidas serão sigilosas, assegurando-se sua confidencialidade e privacidade.

\section{PARTICIPAÇÃo Voluntária:}

A participação é voluntária. Mesmo assinando este termo, você poderá interromper sua participação no estudo, a qualquer momento, sem que isto lhe traga qualquer prejuízo.

\section{ASSinatura do Termo:}

Este Termo será impresso e assinado em duas vias, uma das quais permanecerá com o pesquisador e a outra será entregue ao participante da pesquisa.

\section{Consentimento Pós-Esclarecido:}

Declaro que eu, , fui esclarecido pela pesquisadora, entendi o que me foi explicado e consinto em participar da pesquisa em gravação, fotografia e/ou filmagem, autorizando a divulgação das informações prestadas em eventos e artigos científicos.

São Paulo, de de 20 


\section{E - Questionário Sociodemográfico}

\section{VARIÁVEIS SOCIODEMOGRÁFICAS}

NOME:

Data:

1. Data de Nascimento: Idade:

2. Gênero: ( ) Masculino ( ) Feminino 3. Estado Civil:

( ) Solteiro(a)

( ) Casado(a)

( ) Separado(a)

( ) Divorciado(a)

( ) Viúvo(a)

( ） União estável

4. Escolaridade:
( ) Analfabeto(a)
( ) Ensino fundamental (incompleto)
( ) Ensino fundamental (completo)
( ) Ensino médio (incompleto)
( ) Ensino médio (completo)
( ) Ensino superior (incompleto)
( ) Ensino superior (completo)

5. De acordo com sua escolaridade você estudou, formalmente, 6. É aposentado(a) ou pensionista? （） sim （）não durante anos.

7. Caso seja aposentado ou pensionista, qual a profissão que exercia?

9. Qual o rendimento mensal familiar?

( ) Até um salário mínimo

( ) Mais de 1 a 2 salários mínimos

( ) Mais de 2 a 3 salários mínimos

( ) Mais de 3 a 4 salários mínimos

( ) Mais de 4 a 5 salários mínimos

( ) Mais de 5 a 10 salários mínimos

( ) Mais de 10 salários mínimos

11. Há quanto tempo vive aqui?
8. Exerce atualmente algum tipo de trabalho remunerado, qual?

10. Com quem morava antes:

( ) Sozinho(a)

( ) Somente com o cônjuge

( ) Com os filhos

( ) Com o cônjuge e o(s) filhos

( ) Com o cônjuge, filho(s) e neto(s)

( ) Outra pessoa morava com o(a) senhor(a)

\section{VARIÁVEIS PSICOSSOCIAIS}

\section{Motivos PARA VIVER AQUI}

1. Por que motivos o(a) senhor(a) resolveu viver aqui Morava sozinho (a)

Ficou doente

( ) lugar

Não tinha casa própria

( ) lugar

Não queria dar trabalho para os outros

Preferia morar acompanhado(a)

( ) lugar

Outros. Quais?

( ) lugar

( ) lugar

( ) lugar

\section{PERCEPÇÃO E AUTO-IMAGEM}

2. O/a senhor/a se sente idoso/a?

( ) Sim
( ) Não
( ) Às vezes
( ) NR

3. Na sua opinião, em que idade começa a velhice? anos

( ) Não existe uma idade certa

( ) NR

4. O que é para o/a senhor/a, em poucas palavras, uma boa velhice? (registrar literalmente as respostas da pessoa). 


\section{SATISFAÇÃO GERAL COM A VIDA}

Observe a escada abaixo, pense no que seria a melhor vida possível, em sua opinião. Imagine que essa melhor vida possível fica no alto da escada $\left(n^{\circ} 10\right)$. Pense também no que seria a pior vida possível e imagine que ela está localizada na parte de baixo $\left(\mathrm{n}^{\circ} 1\right)$.

Qual é o ponto dessa escada que melhor reflete a sua satisfação com a sua própria vida neste momento de sua vida? Marque com um "x" o número desse degrau.

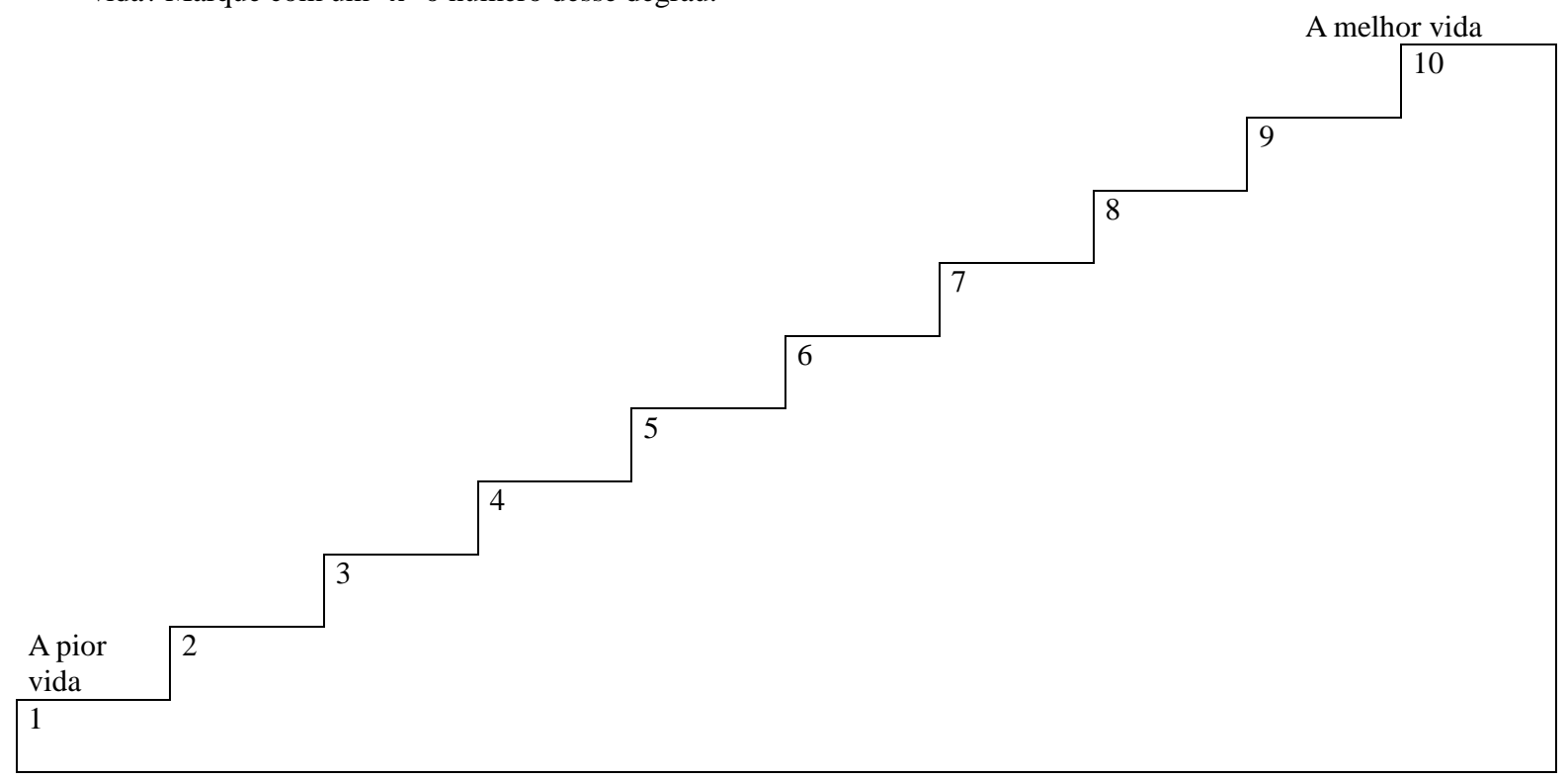

\section{SATISFAÇÃO COM A VIDA REFERÊNCIADA A DOMÍNIOS}

As próximas questões avaliam sua satisfação em relação a aspectos específicos da sua vida. Assinale com um x o ponto que melhor representa o seu grau de satisfação com cada um dos aspectos de acordo com a classificação abaixo:

\begin{tabular}{|l|l|l|l|l|}
\hline $\begin{array}{l}1 \\
\text { muito pouco satisfeito }\end{array}$ & $\begin{array}{l}2 \\
\text { pouco satisfeito }\end{array}$ & $\begin{array}{l}4 \\
\text { mais ou menos satisfeito }\end{array}$ & $\begin{array}{l}4 \\
\text { muito satisfeito }\end{array}$ & muitíssimo satisfeito \\
\hline
\end{tabular}

\begin{tabular}{|l|l|l|l|l|l|}
\hline 1. Minha saúde. & 1 & 2 & 3 & 4 & 5 \\
\hline $\begin{array}{l}\text { 2. Minha saúde hoje comparada com a de outras pessoas da minha } \\
\text { idade. }\end{array}$ & 1 & 2 & 3 & 4 & 5 \\
\hline 3. Minha capacidade física. & 1 & 2 & 3 & 4 & 5 \\
\hline $\begin{array}{l}\text { 4. Minha capacidade física hoje comparada com a de outras pessoas da } \\
\text { minha idade. }\end{array}$ & 1 & 2 & 3 & 4 & 5 \\
\hline $\begin{array}{l}\text { 5. Minha capacidade mental. } \\
\text { 6. Minha capacidade mental hoje comparada com a de outras pessoas da } \\
\text { minha idade. }\end{array}$ & 1 & 2 & 3 & 4 & 5 \\
\hline $\begin{array}{l}\text { 7. Meu envolvimento social hoje. } \\
\text { 8. Meu envolvimento social hoje comparado com a de outras pessoas da } \\
\text { minha idade. }\end{array}$ & 1 & 2 & 3 & 4 & 5 \\
\hline DEPRESSÃO & & 2 & 3 & 4 & 5 \\
\hline
\end{tabular}


Por favor, responda as questões abaixo sobre como você se sente na maior parte do tempo, assinalando SIM ou NÃO, com um x:

\begin{tabular}{|l|l|l|}
\hline 1.Está satisfeita(o) com a vida? & Sim & Não \\
\hline 2. Interrompeu muitas de suas atividades? & Sim & Não \\
\hline 3.Acha sua vida vazia? & Sim & Não \\
\hline 4.Aborrece-se com frequência? & Sim & Não \\
\hline 5.Sente-se de bem com a vida na maior parte do tempo? & Sim & Não \\
\hline 6. Teme que algo ruim lhe aconteça? & Sim & Não \\
\hline 7.Sente-se alegre a maior parte do tempo? & Sim & Não \\
\hline 8.Sente-se desamparada(o) com freqüência? & Sim & Não \\
\hline 9.Prefere ficar em casa ao invés de sair e fazer coisas novas? & Sim & Não \\
\hline 10.Acha que tem mais problemas de memória que outras pessoas? & Sim & Não \\
\hline 11.Acha que é maravilhoso estar viva(o) agora? & Sim & Não \\
\hline 12.Vale a pena viver como vive agora? & Sim & Não \\
\hline 13.Sente-se cheia(o) de energia? & Sim & Não \\
\hline 14.Acha que sua situação tem solução? & Sim & Não \\
\hline 15.Acha que tem muita gente em situação melhor? & Sim & Não \\
\hline
\end{tabular}




\section{F - Roteiro da Entrevista com os Residentes}

Tópicos orientadores a serem abordados:

- Rotina antes de vir para este local (horários de acordar, comer, dormir)

- Tempo de residência no local e forma de ingresso

- Como recebeu a informação sobre as regras gerais do local

- Como recebeu a informação sobre os horários do local

- Qualidade do sono (horário de deitar e levantar, se acorda cansado, se levanta durante a noite)

- Apetite nas horas das refeições

- Aceitação dos horários das atividades no local

- Como seria sua rotina de horários, se pudesse definir

- Como seriam as atividades no local, se pudesse definir

- Percepção do "passar do tempo" nesse local, a religião ajuda? 
G - Questionário dedicado aos Profissionais

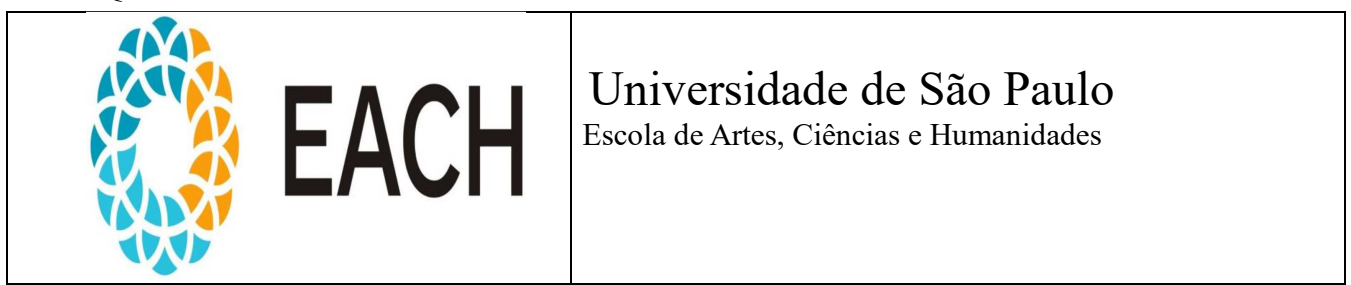

Pesquisa sobre rotinas em Instituições de Longa Permanência para Idosos sobre Sono, Humor e adaptação aos horários das atividades. Pesquisadora: Eva Bettine /Orientador: Luiz Menna-Barreto

Parte II - Dedicada aos Profissionais

Nome:

Data Nascimento:

Função:

1- Quando você começou a trabalhar aqui?

2- Seus horários são regulares ou irregulares na instituição?

3- Você tem uma ou mais queixas de saúde, dentre as opções abaixo?

( ) Insônia

( ) Estresse

( ) Humor instável

( ) Sintomas depressivos

4- Neste espaço escreva alguma sugestão que você tenha para aperfeiçoar o relacionamento com os residentes da Casa.

Agradeço sua participação!

Eva Bettine - Gerontóloga - USP

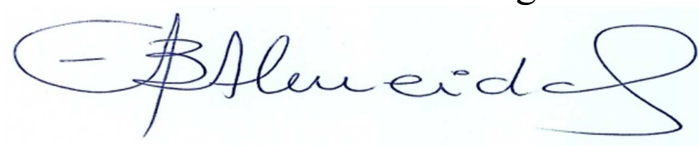


H - Diário de Sono

\section{GRUPO MULTIDISCIPLINAR DE DESENVOLVIMENTO E RITMOS BIOLÓGICOS - UNIVERSIDADE DE SÃO PAULO}

\section{DIÁRIO DE SONO}

Nome:

Data de nascimento:

Instruções:

$\square \square$ Responda a cada questão com a maior honestidade e precisão possível.

$\square \square$ Se você não se lembrar da resposta de alguma pergunta, não se preocupe deixaremos em branco

$\square \square$ Você está participando de um estudo para compreendermos como os residentes desta casa dormem.

Data:

Dia da Semana:

1. A que horas você foi deitar ontem?

2. Quanto tempo você acha que demorou para pegar no sono?

3 . Você lembra de ter acordado e dormido de novo?

a) ( ) Sim quantas vezes?

b) ( ) Não

c) ( ) Não me lembro

4. A que horas você acordou hoje?

5. Quanto tempo você acha que demorou para levantar da cama?

6. Como você foi acordado?
a) () Pelo despertador
b) ( ) Alguém me chamou
c) ( ) Sozinho

7. Você cochilou durante o dia de hoje?
a) ( ) Não
b) ( ) Sim quantas vezes?

\begin{tabular}{|l|l|}
\hline Hora que cochilou & Hora que acordou \\
\hline & \\
\hline & \\
\hline & \\
\hline & \\
\hline
\end{tabular}


I - Questionário para identificação de Indivíduos Matutinos e Vespertinos

Nome:

Idade:

Gênero: M ( ) F ( )

Profissão (quando trabalhava):

Horário habitual de trabalho (quando trabalhava):

Data: I I

Cidade:

1. Considerando apenas seu bem-estar pessoal e com liberdade total de planejar seu dia, a que horas você se levantaria?

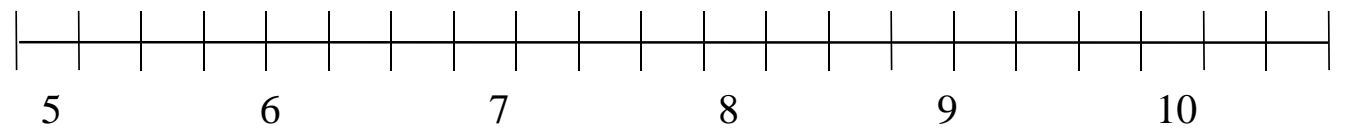

2. Considerando apenas seu bem-estar pessoal e com liberdade total de planejar sua noite, a que horas você se deitaria?

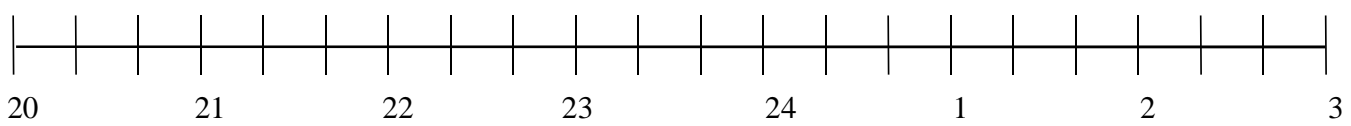

3. Até que ponto você depende do despertador para acordar de manhã? Pontos:

4 - Nada dependente

3 - Não muito dependente

2 - Razoavelmente dependente

1 - Muito dependente

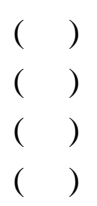

4. Você acha fácil acordar de manhã?

Pontos:

1 - Nada fácil

2 - Não muito fácil

3 - Razoavelmente fácil

4 - Muito fácil

5. Você se sente alerta durante a primeira meia hora depois de acordar? Pontos:

1- 1 - Nada alerta

2 - Não muito alerta

3 - Razoavelmente alerta

4 - Muito alerta

6. Como é seu apetite durante a primeira meia hora depois de acordar? Pontos:

1 - Muito ruim

2 - Não muito ruim

3 - Razoavelmente bom

4 - Muito bom

$(\quad)$
$(\quad)$
$(\quad)$
$(\quad)$

7. Durante a primeira meia hora depois de acordar você se sente cansado? Pontos:

1 - Muito cansado 
2 - Não muito cansado

8. Se você não tem compromisso no dia seguinte e comparando com sua hora habitual. A que horas você gostaria de ir deitar? Pontos:

1- 4 - Nunca mais tarde

3 - Menos que uma hora mais tarde

2 - Entre uma e duas horas mais tarde

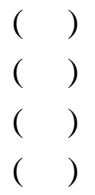

1- 1 - Mais do que duas horas mais tarde

9. Você decidiu fazer exercícios físicos. Um amigo sugeriu o horário das 07:00 às 08:00 horas da manhã, duas vezes por semana. Considerando apenas seu bem-estar pessoal. O que você acha de fazer exercícios nesse horário?

4 - Estaria em boa forma

3 - Estaria razoavelmente em forma

2 - Acharia isso difícil

1 - Acharia isso muito difícil

10. A que horas da noite você se sente cansado e com vontade de dormir?

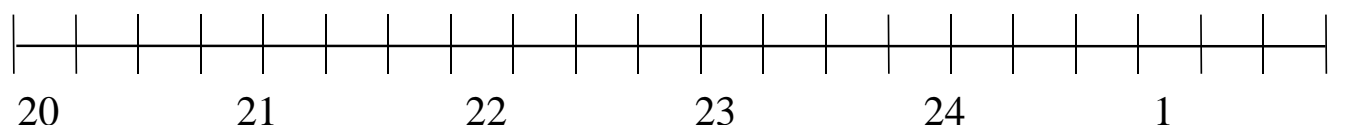

11. Você quer estar no máximo de sua forma para fazer um teste que dura duas horas e que você sabe que é mentalmente cansativo. Considerando apenas o seu bem-estar pessoal, qual desses horários você escolheria para fazer esse teste?

6 - Das 08:00 às 10:00 horas

4 - Das 11:00 às 13:00 horas

$(\quad)$

( )

2 - Das 15:00 às 17:00 horas

$($ )

0 - Das 19:00 às 21:00 horas

$(\quad)$

12. Se você fosse deitar às 23:00 em que nível de cansaço você se sentiria?

0 - Nada cansado

2 - Um pouco cansado

3 - Razoavelmente cansado

5 - Muito cansado

13. Por alguma razão você foi dormir várias horas mais tarde do que é seu costume. Se no dia seguinte você não tiver hora certa para acordar, o que aconteceria com você?

4 - Acordaria na hora normal, sem sono

3 - Acordaria na hora normal, com sono

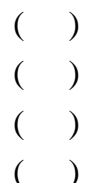

2 - Acordaria na hora normal e dormiria novamente

1 - Acordaria mais tarde do que seu costume

$(\quad)$
$(\quad)$
$(\quad)$
$(\quad)$

14. Se você tiver que ficar acordado das 04:00 às 06:00 horas para realizar uma tarefa e não tiver compromissos no dia seguinte, o que você faria?

1 - Só dormiria depois de fazer a tarefa 
2 - Tiraria uma soneca antes da tarefa e dormiria depois

3 - Dormiria bastante antes e tiraria uma soneca depois

4 - Só dormiria antes de fazer a tarefa

15. Se você tiver que fazer duas horas de exercício físico pesado e considerando apenas o seu bemestar pessoal, qual destes horários você escolheria?

4 - Das 08:00 às 10:00 horas

3 - Das 11:00 às 13:00 horas

( )

2 - Das 15:00 às 17:00 horas

$(\quad)$

1 - Das 19:00 às 21:00 horas

$(\quad)$

$(\quad)$

16. Você decidiu fazer exercícios físicos. Um amigo sugeriu o horário das 22:00 às 23:00 horas, duas vezes por semana. Considerando apenas o seu bem-estar pessoal o que você acha de fazer exercícios nesse horário?

1 - Estaria em boa forma

2 - Estaria razoavelmente em forma

3 - Acharia isso difícil

4 - Acharia isso muito difícil

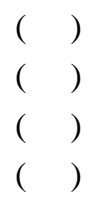

17. Suponha que você possa escolher o seu próprio horário de trabalho e que você deva trabalhar cinco horas seguidas por dia. Imagine que seja um serviço interessante e que você ganhe por produção. Qual o horário que você escolheria? (Marque a hora de início e a hora do fim)

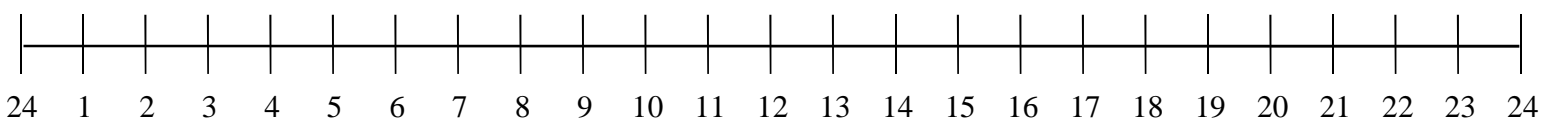

18. A que hora do dia você atinge seu melhor momento de bem-estar?

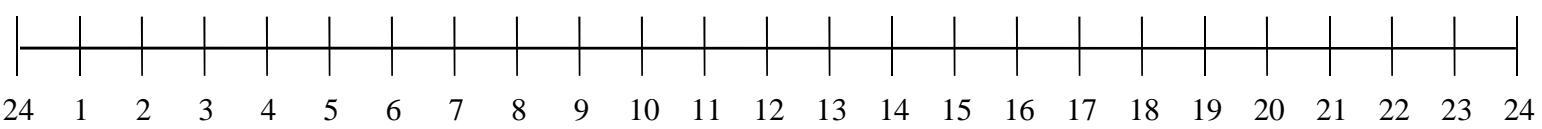

19. Fala-se em pessoas matutinas e vespertinas (as primeiras gostam de acordar cedo e dormir cedo, as segundas de acordar tarde e dormir tarde). Com qual desses tipos você se identifica?

6 - Matutino

4 - Mais matutino que vespertino

2 - Mais vespertino que matutino Matutino

0 - Vespertino 